MARINA BONATELLI

\title{
A subplacenta da paca (Agouti paca, Linnaeus 1766)
}




\section{A subplacenta da paca (Agouti paca, Linnaeus 1766)}

Tese apresentada ao Programa de Pós-graduação em Anatomia dos Animais Domésticos e Silvestres da Faculdade de Medicina Veterinária e Zootecnia da Universidade de São Paulo para obtenção do título de Doutor em Ciências

Departamento:

Cirurgia

Área de concentração:

Anatomia dos Animais Domésticos e Silvestres

Orientador:

Profa. Dra. Marcia Rita Fernandes Machado 
Autorizo a reprodução parcial ou total desta obra, para fins acadêmicos, desde que citada a fonte.

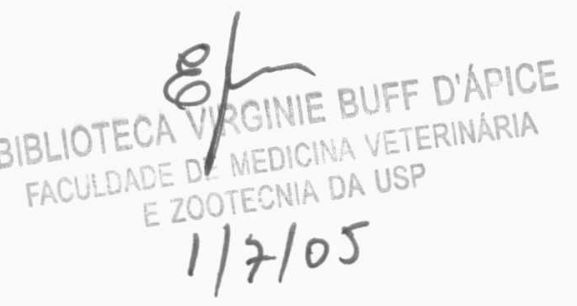

DADOS INTERNACIONAIS DE CATALOGAÇÃO-NA-PUBLICAÇÃO

(Biblioteca da Faculdade de Medicina Veterinária e Zootecnia da Universidade de São Paulo)

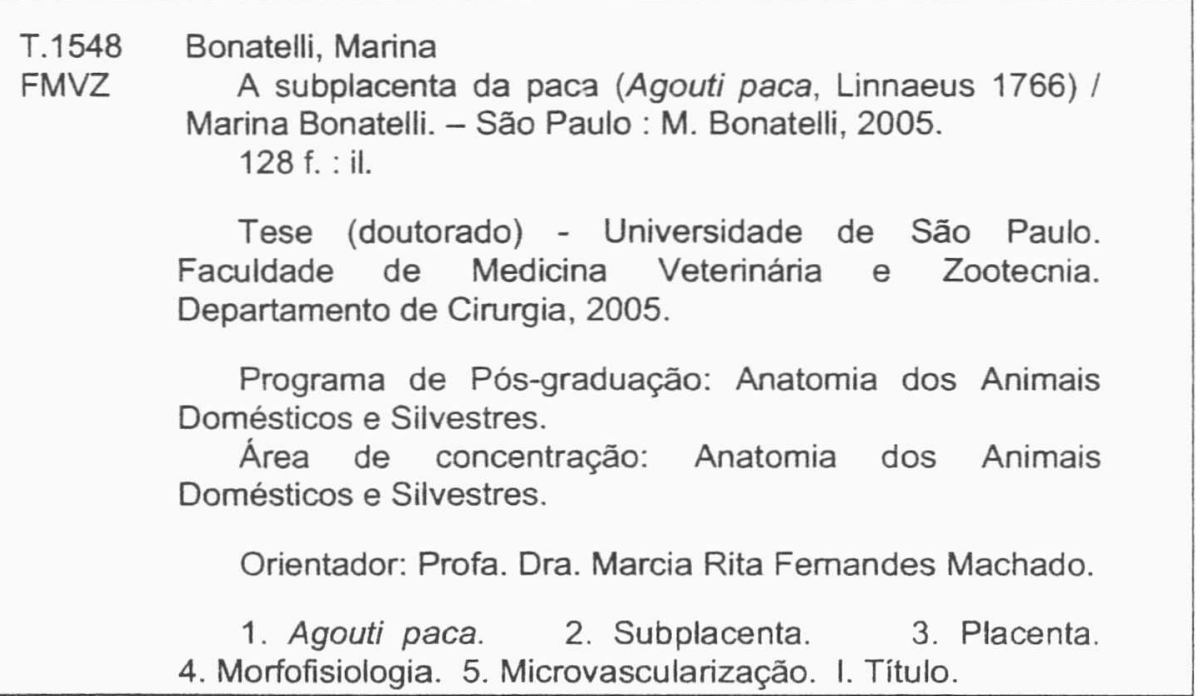




\begin{tabular}{|ccccc|}
\hline & & \multicolumn{2}{c}{ ERRATA } \\
Folha & Parágrafo & Linha & Onde se lê & Leia-se \\
& & & & \\
11 & 1 & 2 & $x f$ & $128 \mathrm{f}$ \\
14 & 1 & 2 & $x f$ & $128 \mathrm{f}$
\end{tabular}




\section{UNIVERSIDADE DE SÃO PAULO \\ Faculdade de Medicina Veterinária e Zootecnia \\ Cidade Universitária "Armando de Salles Oliveira" \\ Comissão Bioética \\ CERTIFICADO}

Certificamos que o Projeto intitulado "A subplacenta da paca (Agouti paca, L. 1766)", Protocolo $\mathrm{n}^{\circ}$ 221/2003, utilizando 6 pacas, sob a responsabilidade da Prof ${ }^{a} r^{a}$ Márcia Rita Fernandes Machado, está de acordo com os princípios éticos de experimentação animal da Comissão de Bioética da Faculdade de Medicina Veterinária e Zootecnia da Universidade de São Paulo e foi aprovado "ad referendun".

(We certify that the Research "The subplacenta of the paca (Agouti paca, L. $1766)^{\prime \prime}$, protocol number $221 / 2003$, utilizing 6 pacas, under the responsibility of Prof ${ }^{\mathrm{a}}$ Dra Márcia Rita Fernandes Machado, agree with Ethical Principles in Animal Research adopted by Bioethic Commission of the Faculty of Veterinary Medicine and Zootechny of University of São Paulo and was approved "ad referendum").

São Paulo, 08 de abril de 2003

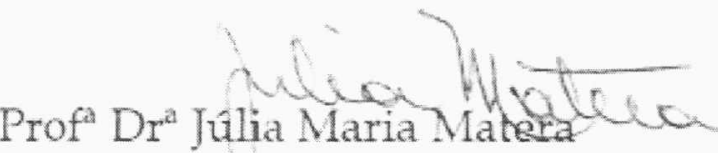

Presidente da Comissão de Bioética

FMVZ/USP 


\section{UNIVERSIDADE DE SÃO PAULO \\ Faculdade de Medicina Veterinária e Zootecnia}

Cidade Lniversitária "Armando de Salles Oliveira"

\section{PARECER}

Interessado: Marina Bonatelli

Assunto: Protocolo de experimentação adotado em experimento animal.

A Comissão de Bioética da Faculdade de Medicina Veterinária e Zootecnia da Universidade de São Paulo, após analisar o projeto sob o número 221/2003, intitulado: "A subplacenta da paca (Agouti paca, L. 1766)": utilizando 08 pacas, referente à Tese de Doutorado, sob responsabilidade da Profa Dra Márcia Rita Fernandes Machado, constatou que o mesmo foi realizado de acordo com os princípios de bioética, adotados por esta Comissäo

São Paulo, 31 de março de 2005

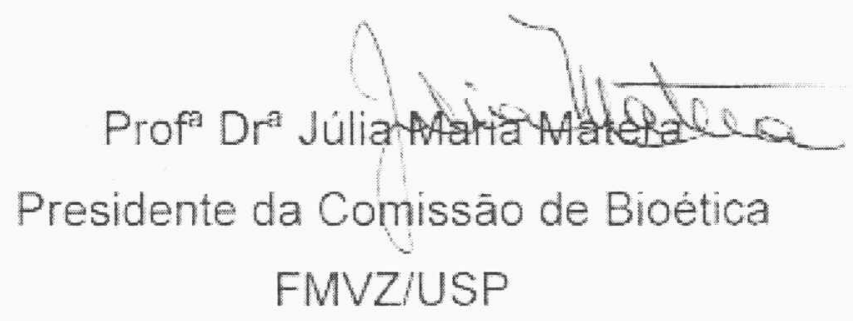


FOLHA DE AVALIAÇÃO

Nome: BONATELLI, Marina

Título: A subplacenta da paca (Agouti paca, Linnaeus 1766)

Data: $221+105$

Tese apresentada ao Programa de Pós-graduação em Anatomia dos Animais Domésticos e Silvestres Faculdade de Medicina Veterinária e Zootecnia da Universidade de São Paulo para obtenção do título de Doutor em Ciências

\section{Banca Examinadora}

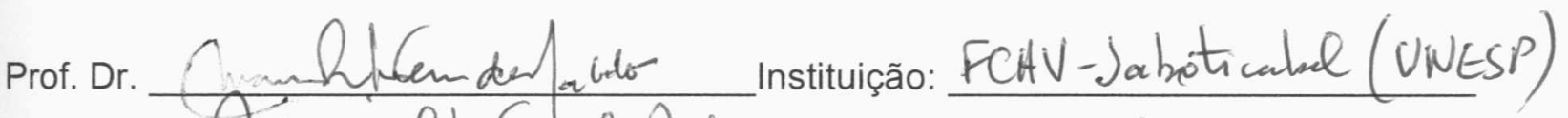

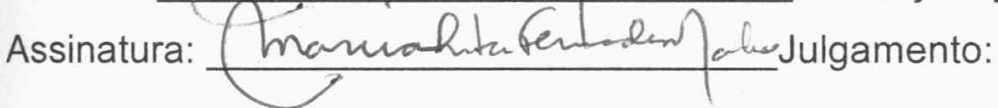

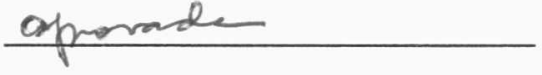

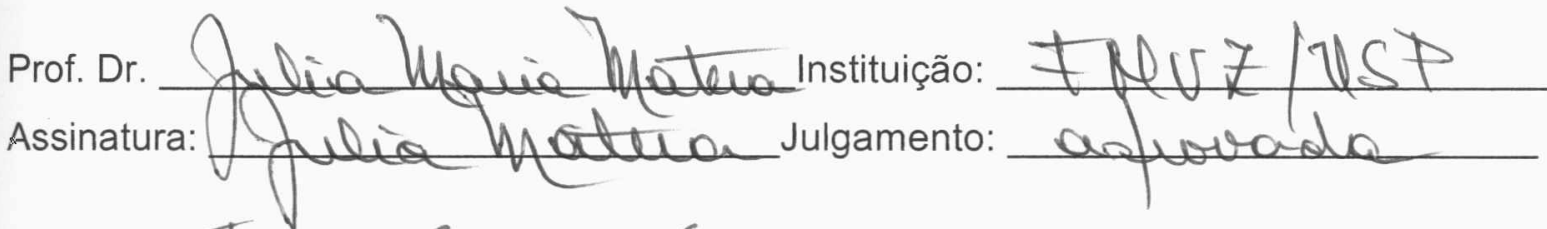

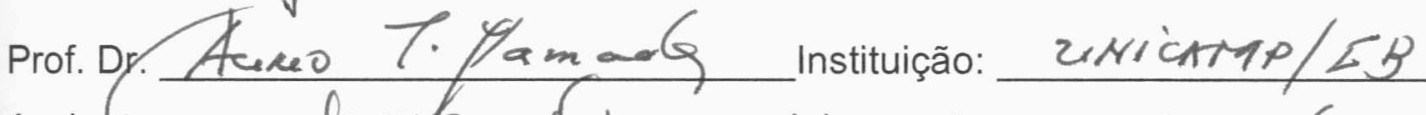
Assinatura: Jempoum Julgamento: afworade

Prof. Dr. José Mandel dos Santos Instituição: Medicina - ABC Assinatura: Impaus. Julgamento: Aprovoda Prof. Dr. Moacir Fuqueo Dliveint Instituição: ESAM-RN Assinatura: dtanco. Julgamento: ApRoUsDA 
Agradeço sinceramente:

Aquele que me deu a vida, essência e liberdade: Deus.

Ao meu Amor, Marcelo, por me amar e fazer compreender o verdadeiro sentido de viver e também pela compreensão nos vários momentos em que tive ausente, às vezes não fisicamente, mas sim espiritualmente e por toda sua ajuda que eu sei que foi de coração.

Aqueles que me conduziram na vida com retidão alimentaram com bons princípios minha essência e possibilitaram minha liberdade: Marcio e Marcia, meus pais.

Aqueles que iniciaram esta família e que com amor guardo em meu coração, Vovó Tereza e Vovô Mané e Mã e Dinha (em memória).

Aquelas com as quais escrevi minha história, que cresceram e que estarão sempre ao meu lado: Vivi e Kaká, minhas queridas irmãs.

Aquela cuja inocência, pureza e amor me enche de alegria: Bia, minha querida sobrinha e afilhada. 
Aos 9 meses comecei a andar, podia ir e vir sozinha, caminhar livremente.

Aos 2 anos comecei a falar, descobri a linguagem que todos entendiam.

Aos 6 anos comecei a ler e escrever, estava pronta para me comunicar com o mundo.

Então, aos 7 anos, já andava, falava, lia e escrevia, eu era realmente independente.

Anos se passaram e a vida me fez entender, que na verdade, ninguém se prepara para a independência, mas sim para o estabelecimento de relações, para as interdependências...

Por isso, aqueles que me concederam o prazer do bom convívio e a ajuda imprescindível para a realização desse trabalho, meu muito obrigada e minha eterna lembrança!!!

Agradeço ao Professor José Manoel dos Santos e ao Professor Idércio Luiz Sinhorini (Professor Doutor do Departamento de Patologia - VPT da FMVZ-USP) que colaboraram diretamente neste trabalho.

"Se vi mais longe, foi porque me apoiei nos ombros de gigantes"

Newton

Aos colegas de pós-graduação pela amizade, carinfio, incentivo e colaborações constantes e pelo convívio diário, compartilhando alegrias e tristezas, tornando a vida na pós-graduação mais familiar. 
Aos amigos secretários do Setor de Anatomia, Maicon, Jaqueline, Cauê, Paula e Graça; e técnicos Ronaldo, Índio e Diogo e também aos funcionários e amigos do ICB, Sr. Gaspar, Edson e Gerson pela atenção sempre dispensada.

Ao Professor Guto e seus orientados que tanto me ajudaram na elaboração de todas as fotos durante este meu período de pós-graduação.

Ao Professor Dr. Gilson Hélio Toniollo, alunos e residentes da UNESP FCAVJ pelas tantas cirurgias realizadas e pelo sucesso em todas elas.

Ao colega Fabrício S. Oliveira pela ajuda dispensada e pelos inúmeros exames ultrassonográficos e protocolos anestésico realizados.

Aos alunos de pós-graduação do Departamento de Histologia e Embriologia, da UNTCAMP pela generosa prontidão, orientação e ajudas prestadas em várias ocasiões assim como tiveram dispostos nos mais diversos horários e dias, como carnaval etc.....

o meu muito obrigada a todos! 
A Universidade de São Paulo (FMVZ-USP) pela oportunidade concedida para realização deste trabalho.

Ao Setor de Animais Silvestres do Departamento de Zootecnia da Faculdade de Ciências Agrárias e Veterinárias de Jaboticabal - UNAESP por ter concedido os animais para o desenvolvimento deste trabalho.

Aos Professores e colaboradores do Curso de pós-graduação em Anatomia dos Animais Domésticos e silvestres pelos ensinamentos.

A FAPESP - Fundação de Amparo a Pesquisa do Estado de São Paulo pelo apoio financeiro. 
Agradeço de forma especial

Ao Prof. Aureo T. Yamada, a quem me adotou e por isso tenko profunda admiração, pela postura humana e profissional, agradeço por me receber em seu laboratório onde muito aprendi, pelo carinho, preocupação e orientação sábia com quem me dirigiu nos caminhos científicos, tornando possivel à realização deste trabalho.

A Profa. Angélica e Profa. Marcia, mulheres corajosas e inovadoras. Serei eternamente grata pela oportunidade.

"Se fosse dado escolher viver sem a amizade ou não viver, preferiríamos não viver."

$$
\text { (Aristótoles - filósofo grego) }
$$

\section{Dear Professor Carter}

Thank you for the collaboration in this research and for the pleasant moments that we passed together in the discussion in our meetings here in Sao Paulo. 


\section{RESUMO}

BONATELLI, M. A subplacenta da paca (Agouti paca, Linneus 1766). [The subplacenta of the paca (Agouti paca, Linneus 1766)]. 2005. x f. Tese (Doutorado em Ciências) - Faculdade de Medicina Veterinária e Zootecnia, Universidade de São Paulo, São Paulo, 2005.

Os roedores da sub-ordem histricomorfa, na qual a paca está classificada, apresentam placentação hemocorial e desenvolvem uma estrutura peculiar junto a sua placenta denominada de subplacenta. Apesar dos relatos de sua presença em diversas espécies, as possíveis funções dessa estrutura permanecem no âmbito especulativo, devido às variações na forma, dimensão e localização, bem como à falta de estudos experimentais focalizando essa estrutura placentária. Foram utilizadas oito placentas de pacas obtidas nos períodos médio e final de gestação, para avaliações das organizações e constituições teciduais, relações anatômicas do órgão por meio da microscopia de luz e eletrônica, aliadas às técnicas de citoquímica, imunocitoquímica e perfusões de traçadores para a rede vascular. Os resultados demonstraram que a subplacenta da paca estava localizada no ápice da placenta corioalantoidiana, separada desta por um tecido mesenquimal e inserida na parede uterina em íntimo contato com o tecido materno. A subplacenta consistia de estruturas lamelares com um eixo de tecido mesenquimal fetal sobre o qual apoiavam-se arranjos epiteliais de citotrofoblastos e sinciciotrofoblastos. Nas áreas de interfaces dos perímetros da subplacenta em contato com o tecido materno foram encontradas ainda populações de células trofoblásticas gigantes multinucleadas. Essas células trofoblásticas gigantes e sinciciotrofoblastos citoqueratina positivas foram também encontradas distantes do perímetro da subplacenta, invadindo profundamente o endométrio, que se apresenta totalmente desestruturado, contendo vasos sangüíneos com as paredes infiltradas 
pelas células trofoblásticas e destituídas de revestimento endotelial, confirmada pela reação vimentina negativa pela imunocitoquímica. Essas localizações de células trofoblásticas apontam para a capacidade invasiva das células trofoblásticas tanto através do leito vascular materno quanto pelos interstícios do estroma endometrial. Verificou-se uma área limítrofe de tecido endometrial decidualizado junto ao miométrio que se mantinha íntegra e que aparentemente conteve a invasividade das células trofoblásticas. Nos espaços interlamelares do interior da subplacenta, em meio ao sinciciotrofoblato, foram encontrados materiais amorfos resultantes da degradação do tecido endometrial retidos durante a progressão e crescimento da placenta para o interior da parede uterina. Nesses espaços, não foram encontrados vasos sangüíneos, porém, no eixo mesenquimal da subplacenta, foram constatados vasos sangüíneos de pequeno calibre, todos vimentina positivos, sugerindo a ausência de vascularização através de sangue materno na subplacenta. Pela localização estratégica, acima da placenta principal e pelos aspectos ultra-estruturais das células citotroblasticas presentes nas lamelas, juntamente com sua intensa marcação pelo PCNA, presume-se que as células da subplacenta possam originar as demais células trofoblásticas, particularmente as sinciciais e as gigantes, ao longo do terço médio da gestação. A vascularização da subplacenta avaliada pela perfusão de látex colorido e pela técnica de corrosão e análise em microscopia eletrônica de varredura comprovou a ausência de vasos de origem materna na subplacenta e demonstrou uma irrigação oriunda da artéria fetal que, após capilarização na subplacenta, dirigia-se para os lóbulos da placenta principal. Esta disposição lembra uma circulação do tipo portal, com uma possível recapilarização dos vasos oriundos da subplacenta junto à placenta principal, 
onde o sangue fetal efetuaria as trocas metabólicas para retornar como sangue oxigenado antes de confluir para a veia fetal no cordão umbilical.

Palavras-chave: Agouti paca. Subplacenta. Placenta. Morfofisiologia. Microvascularização. 


\section{ABSTRACT}

BONATELLI, M. The subplacenta of the paca (Agouti paca, Linneus 1766). [A subplacenta da paca (Agouti paca, Linneus 1766)]. 2005. x f. Tese (Doutorado em Ciências) - Faculdade de Medicina Veterinária e Zootecnia, Universidade de São Paulo, São Paulo, 2005.

The rodents of suborder hystricomorph, in which is classified the Agouti paca, present hemochorial type placentation and develops an unique structure known as subplacenta. In spite of many report of its presence in several species, the possible functions of this structure related to placenta and pregnancy remains speculative, mainly due to the diversity of form, size, localization and lack of experimental studies focusing such a placental structure. In the present study were used eight placentas collected from paca at midle and end stage of gestation in the aim to evaluate their tissue components and organization, anatomical relation of the organ at light and electron microscopy level, associated with cytochemical and immunocytochemical techniques and perfusion of vascular bed. The results showed the subplacenta was localized at apical portion of chorioallantoic placenta of paca, separated from this by mesechimal tissue and inserted in the uterine wall in intimate contact with maternal tissue. The subplacenta consisted of lamellar structures with mesenchimal axis of fetal origin on which, cytotrophoblast and syncytiotrophoblasts layers were organized as epithelial sheets. The interfaces at peripheral portion of subplacenta in contact with maternal tissue were also found populations of multinucleated giant trophoblast cells. These giant cells and syncytiotrophoblast were cytokeratin positives and were found far from the limits of subplacenta, deeply invading the completely damaged endometrium, as did the maternal vessels showing presence of trophoblast cells in their walls devoid of endothelial cells attested by vimentin and cytokeratin immunostaining. These findings 
suggest the invasive capability of trophoblast cells either through the maternal vascular bed and interstitium of endometrial stroma. However, it was seen a well defined border line of helthy decidualized endometrium near the miometrium that seems to retain the invasive progression of trophoblast cells. In the interlamellar space of subplacenta formed by syncytiotrophoblast, it was found amorphous materials originated from degradation of endometrial tissue retained during the progression and growth of placenta into the uterine wall. In these interlamellar spaces were not found blood vessels, but in the mesenchimal axes were found vimentin positive small vessels, which suggest absence of maternal vascularization inside the subplacenta. The strategical localization of subplacenta upside of chorioallantoic placenta of paca and the ultra structure of cytotrophoblast cells and their strong reaction to PCNA (proliferating cell nuclear antigen) supports these subplacental cells could be the source of trophoblast cells, namely the giant and syncytiotrophoblast. The vascularization of subplacenta evaluated by stained latex perfusion and by microvascular casting seen at scaning electron microscopy clearly showed the absence of maternal vascularization in the subplacenta. The blood supply of subplacenta seems to be exclusively from fetal artery which after capilarization in the subplacenta flows to the lobules of main placenta. Such a blood flow remind the portal type circulation, being the second capilarization of venous type vessels coming from the subplacenta inside the lobulules of the main placenta, where the fetal blood could make the metabolic changes to return with enough oxygenation level before join to the fetal vein in the umbilical cord.

Key words: Agouti paca. Subplacenta. Placenta. Morphophysiology. Microvascularization. 


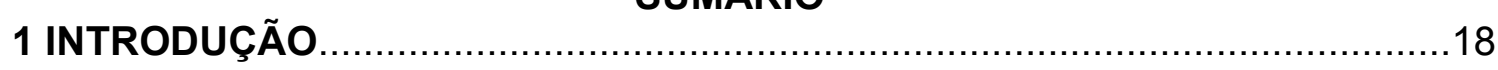

2 OBJETIVOS

3 REVISÃO DE LITERATURA

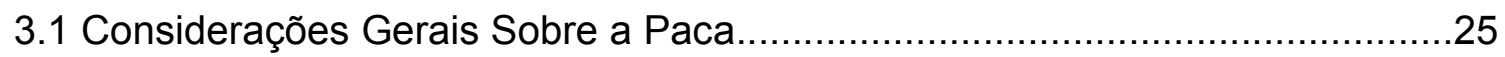

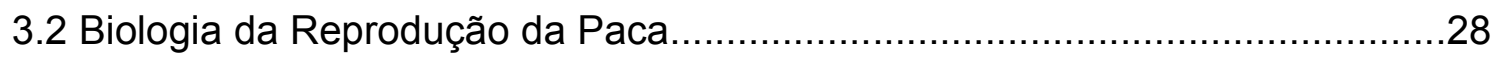

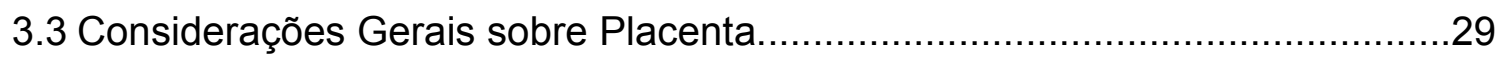

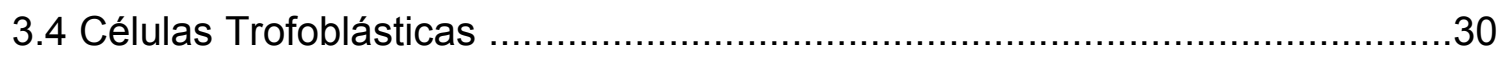

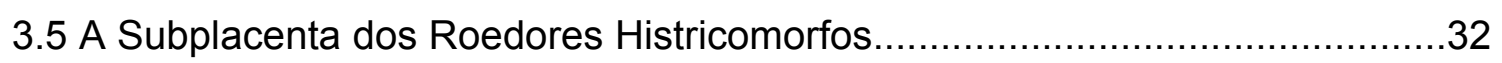

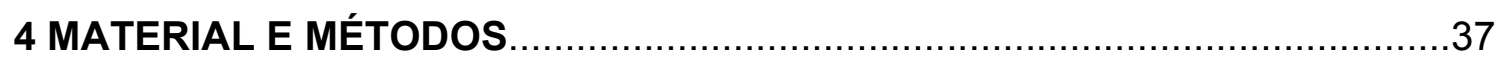

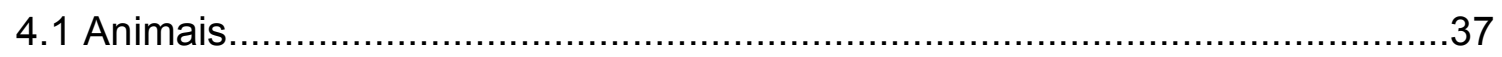

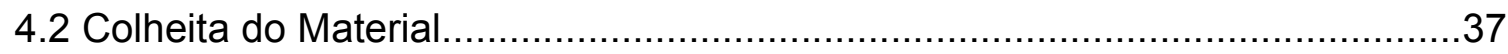

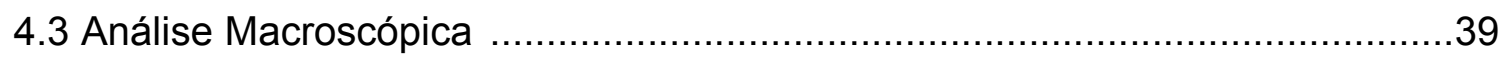

4.4 Processamento para Embebição em Parafina...............................................40

4.5 Reações Citoquímicas e Imunocitoquímica..................................................

4.5.1 Reação citoquímica de PAS (ácido periódico - Shiff)...................................41

4.5.2 Reações para Citoqueratina, Vimentina e PCNA........................................41

4.6 Processamento para Microscopia Eletrônica de Transmissão..........................42

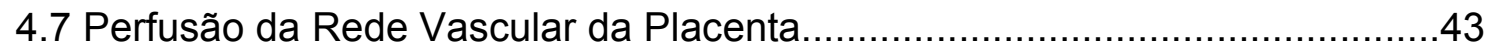

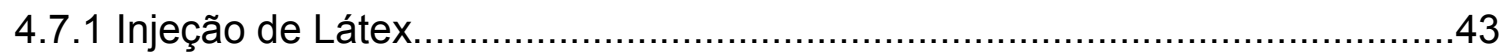

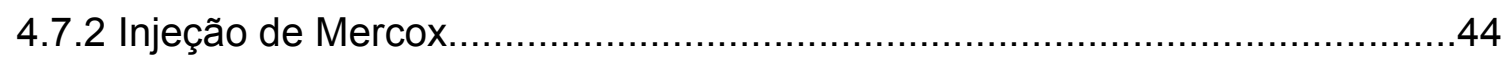

5 RESULTADOS

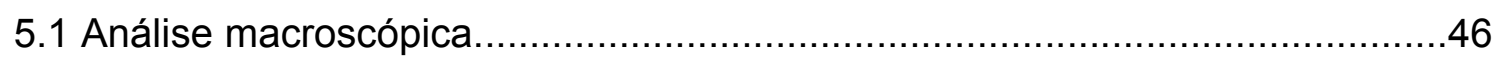

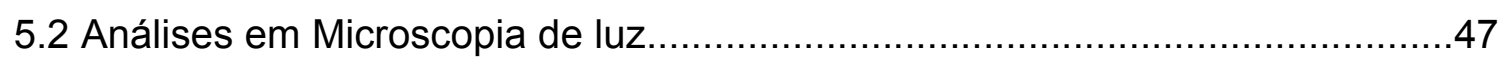

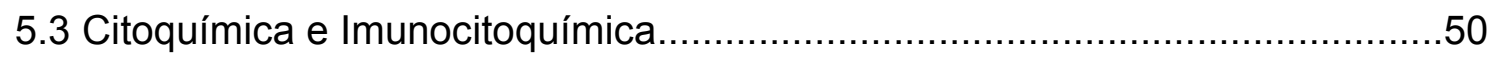

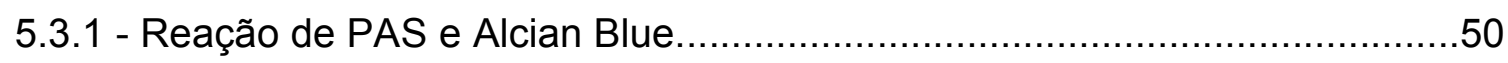

5.3.2 - Reações para Citoqueratina, Vimentina e PCNA.....................................51

5.4 Microscopia Eletrônica de Transmissão da Subplacenta.................................52

5.5 Vascularização da

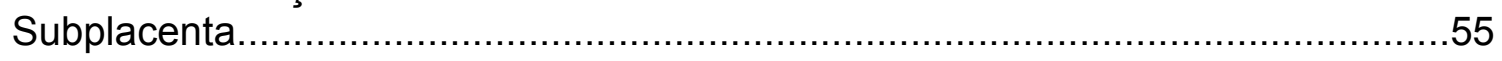

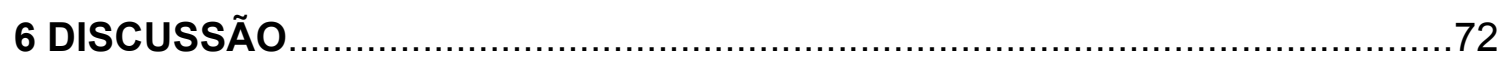

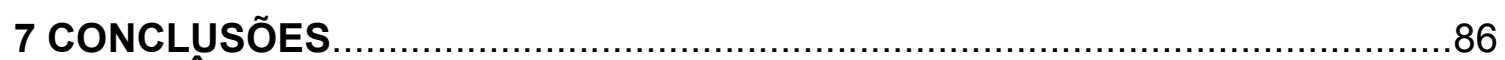

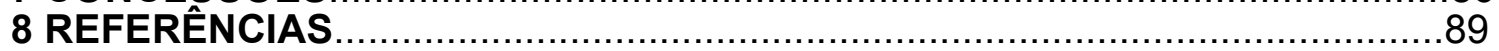

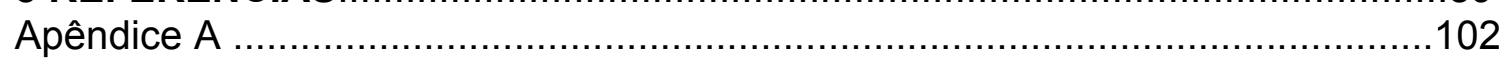




\section{INTRODUÇÃO}

O aporte do embrião para o sucesso da viviparidade em mamíferos é de extrema importância e envolve o desenvolvimento de uma população de células que, diferente dos embrioblastos, não participam da formação do corpo do embrião. Seu papel funcional é estabelecer relações interativas com o organismo materno, criando as condições necessárias para o desenvolvimento embrionário. Essas células são denominadas células trofoblásticas.

As interações materno-embrionárias mediadas pelo trofoblasto se iniciam com o processo de implantação do blastocisto no endométrio e culminam com a formação de um órgão comprometido com o sistema de trocas metabólicas materno-fetais: a placenta.

Os embriões dos mamíferos vivíparos recebem nutrição derivada da mãe durante todo o seu desenvolvimento e permanência no útero. Esse processo trófico é mediado pela placenta, um órgão transitório que se forma durante o período de gestação, constituído de membranas fetais justapostas em associação com tecidos maternos.

Embora o termo placenta (Latin placenta, bolo plano, descritivo para a forma da placenta humana) evoque a forma de um disco, as placentas dos mamíferos apresentam diferentes contrastes de morfologia, persistência e tenacidade dos anexos sendo, contudo, totalmente uniformes quanto à função: a de troca fisiológica entre o feto e a mãe (PERRY, 1981; WIMSATT, 1975). 
Além de participar na ancoragem e posicionamento do embrião na parede uterina, as células trofoblásticas também estão envolvidas na obtenção do espaço para o crescimento do concepto e na manutenção deste, mesmo antes de a placenta estar plenamente formada (BILLINGTON, 1971; KATZ; ABRAHAMSOHN, 1987). O desenvolvimento de tais funções pelas células trofoblásticas está intrinsecamente associado a um processo de diferenciação e à expressão de um comportamento invasivo e fagocitário por parte dessas células (BILLINGTON, 1971; KAUFMAN, 1983; STEVENS, 1983).

Em roedores, como os camundongos, a implantação embrionária se inicia na região antimesometrial, onde as células trofoblásticas do pólo abembrionário perdem a capacidade proliferativa, tornam-se poliplóides e passam a ser denominadas células gigantes (BEVILACQUA; ABRAHAMSOHN, 1988,1989; DICKSON, 1969; SCHLAFKE; ENDERS, 1975; TACHI et al., 1970). Já no pólo embrionário, o trofoblasto polar que recobre a massa celular interna mantém a capacidade de multiplicação, dando origem a uma excrescência que se projeta no lúmen na região mesometrial, conhecida e presente apenas nos camundongos, denominados cone ectoplacentário (COOP, 1979). As células mais periféricas dessa estrutura também sofrem um processo de implantação do embrião na mesma região e juntamente com as demais células do cone ectoplacentário, que se diferenciam essa população celular, formarão a porção fetal da placenta (MEHROTRA, 1984, 1988; SNELL; STEVENS, 1966).

Uma vez alcançado o estroma endometrial, células trofoblásticas gigantes invadem os vasos sangüíneos uterinos, rompendo-os e mantendo contato direto com o sangue materno. É a partir dessa superfície de troca que ocorre a aquisição de 
nutrientes, garantindo assim o desenvolvimento embrionário até a formação da placenta (DAVIS; HESSELDAHL, 1971).

Células trofoblásticas também secretam hormônios, enzimas e moléculas reguladoras, participam da proteção do embrião contra agentes patogênicos presentes no organismo materno e, juntamente com outras estruturas maternas, conferem ao embrião proteção imunológica (BILLINGTON, 1975; KIRBY, 1971). As atividades funcionais expressas pelo trofoblasto nem sempre são concomitantes, variam ao longo da gestação e são dependentes da diferenciação de populações específicas de células trofoblásticas, de modo a suprir diferentes necessidades, nas diferentes fases do desenvolvimento embrionário ou fetal. Apesar da importância desses eventos, o conhecimento dos mecanismos moleculares envolvidos em cada um desses processos é ainda bastante rudimentar.

Dentre os roedores, a sub-ordem dos histricomorfos apresentam uma estrutura peculiar denominada subplacenta associada à placenta (DAVIES; DEMPSEY; AMOROSO, 1961a,b; KAUFMANN, 2003; MOSSMAN, 1987), constituída essencialmente de células trofoblásticas. Porém a função dessa estrutura não está ainda determinada.

Bonatelli et al. (2005), estudando a placentação em paca, descreveu a ocorrência da subplacenta nessa espécie e aponta a necessidade de estudos para estabelecer os parâmetros morfológicos e funcionais dessas estruturas, visando à compreensão da fisiologia da reprodução dessas espécies animais e correlatas.

De acordo com Kaufmann (2003), a partir das observações em diversas espécies de histricomorfos, a subplacenta pode dar origem aos trofoblastos que 
organizam a placenta, assim como desempenhar importante papel regulador como órgão endócrino temporário da gestação. 
Objetivos 


\section{OBJETIVOS}

O presente estudo foi delineado para avaliar a organização e desenvolvimento da subplacenta da paca (Agouti paca) a partir do terço médio de gestação por meio de análises morfológicas, citoquímicas e imunocitoquímicas, em nível de microscopia de luz, e a ultra-estrutura, pela microscopia eletrônica de transmissão, assim como a microvascularização desse órgão.

2.1 Objetivos Parciais:

1 - Análise da variação da organização histológica da subplacenta no terço médio e no final da gestação.

2 - Análise ultraestrutural da celularidade da subplacenta e suas formas de associação no terço médio e no final da gestação.

3 - Análise da variação nos componentes da interface subplacentaendométrio, por meio de métodos citoquímicos e imunocitoquímicos, entre o terço médio e o final da gestação.

4 - Avaliação da microvascularização da subplacenta. 
Revisão de Literatura 


\section{REVISÃO DE LITERATURA}

\subsection{Considerações Gerais Sobre a Paca}

A paca (Agouti paca), depois da capivara, é o maior roedor brasileiro e está inserida no filo Chordata, classe Mammalia, ordem Rodentia, subordem histricomorfa, família Dasyproctidae, sendo denominada agouti, no exterior e, ainda, conhecida como coelho pintado, no Panamá; tapezcuinte, na Costa Rica; lapa, na Venezuela; boruga, na Colômbia e majáz, no Peru.

Possui corpo robusto, cabeça volumosa, olhos grandes e orelhas médias. Seus pêlos são curtos de tonalidade que varia do castanho avermelhado ao castanho pardo, predominando os de coloração marrom, dispondo-se, ainda, no sentido longitudinal do corpo, quatro fileiras de listras esbranquiçadas. A cauda é muito curta, medindo de um a sete centímetros de comprimento. Seus membros apresentam coloração branca ou amarelada, com quatro dedos nos torácicos e cinco nos pélvicos, ambos com unhas de formato cônico.

O crânio da paca é muito peculiar, pois apresenta o arco zigomático expandido, formando uma espécie de bolsa interna, a qual, ao mesmo tempo, aumenta a potência da mandíbula e amplia os sons emitidos pelo animal ao ranger seus dentes. Nos machos, esse osso é muito desenvolvido, tornando sua cabeça maior do que a da fêmea, embora o dimorfismo sexual, nessa espécie, seja pouco acentuado. Os filhotes 
nascem com aproximadamente 500 gramas de peso, e os adultos chegam a pesar de 6 a 12 quilos, medindo de 35 a $60 \mathrm{~cm}$ de comprimento.

Vive em tocas com duas ou mais saídas, as quais, geralmente, são obstruídas com folhas para evitar a entrada da luz. Alimenta-se à noite, ou nos períodos crepusculares, sempre se escondendo entre a vegetação baixa, protegendo-se do sol, pois é acometida de fotofobia.

A paca é um animal solitário e territorialista; os contatos sociais são realizados por meio do olfato e da demarcação de territórios, que é realizada ao esfregar a região perineal de seu corpo, local onde se aloja uma glândula que exala substâncias odoríferas; também o macho, geralmente, ao encontrar a fêmea, marca-a levemente com um jato de urina para que se crie um laço afetivo entre ambos na mistura do cheiro.

Em determinados momentos, um casal pode até dormir na mesma toca, dividindo o mesmo território, que, na natureza, gira ao redor de dois hectares por animal. Os indivíduos geralmente não toleram nenhum outro indivíduo com cheiro estranho e costumam manter-se a distância, pois, caso ocorra um encontro, as brigas, na maioria dos casos, são fatais.

Embora em seu habitat natural seja pouco sociável com outros animais da mesma espécie, em cativeiro, quando bem manejada desde filhote, pode ser criada facilmente em grupos. Vive entre 8 e 12 anos, mas existem relatos de pacas de até 16 anos de idade em cativeiro, quando os animais são bem alimentados e manejados.

Na natureza, a paca é um animal de hábitos noturnos que permanece durante o dia dormindo, escondida em tocas escuras, covas ou troncos secos, saindo apenas 
algumas vezes durante o dia para se alimentar ou beber água, geralmente, na sombra ou ao anoitecer. Seu habitat preferido varia de florestas densas a pântanos, sendo estes encontrados o mais próximo possível de rios e lagos, pois possui grande capacidade para nadar e mergulhar. Algumas vezes é encontrada em bosques e áreas planas e menos densas. Ela é herbívora, alimentando-se de folhas, raízes e frutos caídos no chão; em cativeiro, além desse tipo de alimento, ingere, com boa aceitação, ração apropriada para roedores.

É muito agressiva e, para defender sua cria ou invasão de sua toca da invasão de outras pacas, mesmo pelas de sexo oposto, ataca, utilizando seus dentes afiados e emitindo grunhidos agudos.

Embora pareça pesada, é ágil e salta muito bem. É capaz de nadar com facilidade, principalmente quando acuada, dando mergulhos longos e muitas vezes profundos, podendo ficar imersa por até 20 minutos. Seus principais predadores, além do homem, são os grandes felinos, como a onça e o jaguar, ou ainda, os cães domésticos.

Esse roedor torna-se sujeito a intensa ação de caçadores devido ao seu tamanho e ao sabor de sua carne muito apreciado. Entretanto sua sobrevivência está ameaçada, não somente pelo fator predatório, mas também pela destruição do habitat em função do desmatamento e da drenagem de áreas alagadas para implantação de projetos florestais e agrícolas. Tais empreendimentos, à medida que são implantados, vão eliminando as condições de vida desse animal. A preservação dessa espécie dependerá, entre outros, do perfeito conhecimento da biologia do processo reprodutivo e de seu manejo em cativeiro. 


\subsection{Biologia da Reprodução da Paca}

Segundo Hosken e Silveira (2001), uma fêmea atinge a maturidade sexual aos 8 meses e o macho, aos 10 meses de idade. Os animais só se aceitam quando há o acasalamento, repelindo-se após esse período. Geralmente, criam um filhote por gestação, raramente ocorrendo o nascimento de dois filhotes.

Em cativeiro, aloja-se um macho com várias fêmeas; no caso de ficarem prenhes, devem ser isoladas por ocasião do parto, para evitar o infanticídio, comum na espécie. Após o parto, caso a fêmea não permaneça com o macho, ela deve ser colocada em contato com ele logo após o nascimento de sua cria, para o aproveitamento do cio pós-parto.

O ciclo estral da fêmea dura, em média, 31 dias. O cio ocorre logo após o nascimento e, novamente, após o desmame. Nesses animais, já é conhecido o período de prenhez, o qual dura em média de 135 a 139 dias (OLIVEIRA, 2001), nascendo apenas um filhote por parto.

Em relação ao neonato, a medida do comprimento entre sua cabeça e a porção distal de sua cauda é, em média, de 23 centímetros (MATAMOROS, 1982), ou entre 24 a 30 centímetros, de acordo com Mondolfi (1972), ou ainda, de 33,46 centímetros segundo Oliveira (2001); seu peso corpóreo varia de 550 a 800 gramas, e está ao redor de 710 gramas, segundo Kleiman et al. (1980), e é, aproximadamente, de 650 gramas, para Matamoros (1982) e 754 gramas por Oliveira (2001). O período de lactação abrange 90 dias (CLARK; OLFERT, 1986; MATAMOROS, 1982). 
Matamoros (1982) relatou intervalo entre partos de 97 a 268 dias para 11 fêmeas mantidas em cativeiro na Costa Rica. De acordo com Meritt (1989), esse intervalo foi, em média, de 178 dias, variando de 137 a 251 dias, para fêmeas trazidas da natureza e criadas em cativeiro; já para fêmeas nascidas em cativeiro esse intervalo foi, em média, de 212 dias, variando de 153 a 294 dias. Smythe (1991) registrou um intervalo médio de 186,67 dias, variando de 162 a 186 dias e Nogueira (1997) refere um intervalo entre partos de 195,8 dias, que, segundo Oliveira (2001), seria de 232 dias.

Na paca, a placenta se assemelha à de outros roedores histricomorfos. Essa é dividida em vários lóbulos que compõe o labirinto, separados por trofoblasto interlobular. A barreira interhemal é do tipo de hemomonocorial e Bonatelli et al. (2005) constataram a presença de subplacenta.

\subsection{Considerações Gerais sobre Placenta}

A palavra "placenta" foi empregada por Realdus Columbus (1516-1559 apud AMOROSO, 1952) ao descrever a placenta humana, definindo-a como uma estrutura formada pela fusão de material residual, na forma de um bolo redondo, e esse termo passou, então, a ser utilizado genericamente para referir-se à placenta discoidal dos humanos, lagomorfos e roedores. 
Mossman ${ }^{1}$ (1937 apud AMOROSO, 1952), definiu a placenta como "qualquer aposição íntima ou fusão entre órgãos fetais e matemos para o estabelecimento de trocas fisiológicas". Wimsatt (1962) complementou essa definição, acrescentando que as funções desempenhadas por essa estrutura, dependiam, direta ou indiretamente, da fusão ou interação entre os tecidos uterinos e fetais, e incluíam, especificamente, nutrição fetal histiotrófica ou hemotrófica, respiração, excreção, secreção e regulação, entre outras.

Verifica-se uma extraordinária diversidade de estruturas placentárias que foram desenvolvidas durante a evolução, nas diferentes espécies de mamíferos para cumprir sua função principal, isto é, promover de forma eficiente as trocas materno-fetais. Essa diversidade compreende desde o tipo e o número de membranas envolvidas, a forma externa do órgão, o padrão geométrico de interdigitação materno-fetal, o tipo e o número de camadas de tecido que separam os sangues materno e fetal, até o arranjo geométrico dos vasos envolvidos com as trocas materno-fetais (LEISER; KAUFMANN, 1994).

Não obstante a essa diversidade de forma e estruturação, a placenta caracteriza-se por sua constituição celular fundamental, o trofoblasto.

${ }^{1}$ MOSSMAN, H. W. Comparative morphogenesis of fetal membranes and accessory uterine structures. Contr. Embryol. Carneg. Inst. v. 26, p. 129-246, 1937. 


\subsection{Células Trofoblásticas}

O trofoblasto origina-se das células trofectodérmicas que revestem o blastocisto e é responsável pelo contato, adesão e ancoragem do embrião à parede uterina no processo de implantação embrionária (COOP, 1979; ENDERS; WELSH, 1993).

Em animais com placentação do tipo hemocorial, essas células trofoblásticas proliferam intensamente e diferenciam-se em sinciciotrofoblastos nos primatas (BLANKENSHIP et al., 1993; ENDERS; KING, 1991), ou em células gigantes em roedores (BEVILACQUA; ABRAHAMSOHN 1988; GARDNER et al., 1973; KANAI AZUMA et al., 1994; MÜNTENER; HSU, 1977). A atividade invasiva dessas células tem sido apontada como imprescindível para o sucesso da implantação embrionária e placentação (GRAHAM; LARA, 1992).

Segundo Caluwaerts et al. (2005), a invasão de trofoblasto na parede uterina é uma importante característica da placentação hemocorial e, em várias espécies, como, por exemplo, o rato, ocorre uma série de mudanças, dentre as quais as artérias espirais com a invasão endovascular de trofoblasto, incluindo substituição temporária do endotélio, deposição de fibrina e rompimento do músculo liso vascular.

A rigorosa regulação das propriedades invasivas das células trofoblásticas é necessária para o sucesso da gestação nos primatas superiores, incluindo o homem (RAMSEY; DONNER, 1980); uma vez que, esta tem a finalidade única de consolidar a placentação. 
3.5 A Subplacenta dos Roedores Histricomorfos

O emprego do termo subplacenta foi utilizado por $\operatorname{Minot}^{2}$ (1889 apud DAVIES; DEMPSEY; AMOROSO, 1961b) para referir uma estrutura na placenta do coelho e, de acordo com Grosser ${ }^{3}$ (1927 apud AMOROSO 1952), a subplacenta seria uma estrutura de considerável tamanho, situada no teto da escavação central do disco placentário, composta por células gigantes resultantes de uma peculiar transformação da camada sincicial periférica. O termo subplacenta foi usado mais tarde para indicar uma estrutura diferente na placenta da cobaia, mas de localização semelhante.

A subplacenta é encontrada em roedores da sub-ordem histricomorfos e tem sido descrita na chinchila (TIBBITTS; HILLEMANN, 1959), no porco-espinho (PERROTA, 1959), na cobaia (DAVIES; DEMPSEY; AMOROSO, 1961a, b; KAUFMANN; DAVIDOFF, 1977; ROBERTS; PERRY, 1974; UHLENDORF; KAUFMANN, 1979), na nutria (HILLEMANN; GAYNOR, 1961), no gerbil (FISCHER; FLOYD, 1972), na chinchila (KING; TIBBITTS, 1976), no rato-da-cana - Thryonomys swinderianus (ODUOR-OKELO; GOMBE, 1982,1984), no castor canadense (FISCHER, 1985), na capivara (SOIRON, 1993; KAUFMANN, 2003), no octodon (BOSCO; DIAZ; BORAX, 1997; MESS, 2003), no petromus (MESS, 2003), na paca (BONATELLI et al., 2001,2005) e no mocó (OLIVEIRA et al., 2005).

\footnotetext{
${ }^{3}$ MINOT, C. S. Uterus and embryo. I Rabbit; II. Man. Journal of Morfology, v. 2, 341, 1889.

${ }^{4}$ GROSSER, $O$. Frühentwicklung, eihautbildung und placentation des menshen und de saugetiere. Munchen, 1927.
} 
Sua localização difere entre as espécies, pois está localizada nas áreas central e mesometrial do disco placentário na chinchila (HILLEMANN; GAYNOR, 1961) e no mongolian gerbil (FISCHER; FLOYD, 1972); na cobaia está disposta no teto da escavação central (ROBERTS; PERRY, 1974; DAVIES; DEMPSEY; AMOROSO,

1961a,b), assim como no Octodon degus (BOSCO; DIAZ; BORAX, 1997), na capivara (SOIRON, 1993; KAUFMAN, 2003), no mocó (OLIVEIRA et al., 2005) e na paca (BONATELLI et al., 2005).

O arranjo histológico básico da subplacenta é de uma camada múltipla de citotrofoblasto, do qual o trofoblasto sincicial se desenvolve, na superfície oposta ao mesênquima fetal; o sincício subplacentário possui grandes acúmulos de glicogênio, REG, aparelho de Golgi extensamente espalhado e poucas mitocôndrias. As superfícies do sincício que limitam as lacunas possuem numerosos microvilos. As lacunas contêm, freqüentemente, uma substância eletrodensa finamente granular. As células citotrofoblásticas formam uma camada contínua no início da gestação, e possuem numerosos poliribossomos livres, poucos retículos endoplasmáticos, poucas mitocôndrias e aparelho de Golgi pequeno. As células do citotrofoblasto são unidas umas as outras e também à lâmina basal, através de desmossomos, variando consideravelmente o espaço intercelular conforme descreveu King e Tibbitts (1976), bem como Uhlendorf e Kaufmann (1979) e Davies, Dempsey e Amoroso (1961b) sobre a subplacenta da cobaia. Oduor-Okelo e Gombe $(1982,1984)$ também referiram a subplacenta do rato-da-cana (Thryonomys swinderianus); Fischer (1985), a do castor canadense; Bosco; Diaz; Borax (1997) a do Octodon degus e Bonatelli et al. (2005) a da paca. 
Essa região sofre processo de falência de seus tecidos no período final de gestação; evidências de degeneração celular foram observadas na subplacenta do mocó por Oliveira et al. (2005), especialmente próximo da decídua basal, onde células com núcleos picnóticos foram notadas, assim como também escombros celulares; isso foi relatado também por Miglino et al. (2002) na subplacenta da capivara, cutia e da paca.

Kaufmann e Davidoff (1973) descreveram a circulação da subplacenta como possuindo, até o $20^{\circ}$ dia aproximadamente, uma circulação promovida por vasos maternos e, depois desse período, ao redor do $28^{\circ}$ dia, cessada em todas as regiões da subplacenta. Embora houvesse alguns vasos fetais na escavação central na hora da formação da subplacenta, eles não entravam em contato com o trofoblasto. Entre o $23^{\circ}$ e o $27^{\circ}$ dia, o período durante o qual a circulação materna retrocedia, os primeiros vasos fetais penetravam mais profundamente entre os lóbulos de trofoblasto. A vascularização fetal da subplacenta só era completada no $32^{\circ}$ dia. Depois do $55^{\circ}$ dia, os vasos eram obliterados no curso dos processos degenerativos da subplacenta. Do $58^{\circ}$ dia em diante, havia apenas alguns poucos vasos fetais nessa região. Relatos de Uhlendorf e Kaufmann (1979) e de Wolfer e Kaufmann (1980), estudando a placentação da cobaia, são semelhantes, quanto a vascularização da subplacenta não receber sangue materno e fetal ao mesmo tempo, e sim, primeiramente o materno, que começava no $9^{\circ}$ dia e permanecia até o $12^{\circ}$ dia da gestação, enquanto a vascularização feita por vasos fetais conserva-se até o $26^{\circ}$ dia, quando as lacunas maternas já se haviam fechado. Relatos anteriores menos precisos já apontavam para a ausência de vascularização materna nas subplacentas da nutria (HILLEMANN; GAYNOR, 1961) e 
do castor (FISCHER, 1965) enquanto relatos mais recentes obtidos na capivara (KAUFMANN, 2003,2004), demonstram resultados semelhantes.

A vascularização das placentas dos roedores histricomorfos foi descrita por Miglino et al. (2004) como suprida por uma única artéria, e Carter et al. (1998) ao realizarem reações de imunohistoquímica na placenta da cobaia, comprovaram por meio da reação positiva a vimentina, que esse vaso era de origem fetal, ainda Miglino et al. (2004) relataram que este vaso se dividia e seus ramos ao adentrarem a subplacenta seguiam um curso tortuoso, com dilatações e constrições semelhantes àquelas encontradas em uma glândula endócrina, assim como Murakami et al. (1988) descreveram o ovário de ratas, com especial referência à ovulação e a luteinização.

Para tanto, várias funções foram sugeridas para essa estrutura. Para Davies, Dempsey e Amoroso (1961b) a subplacenta da cobaia é responsável pela produção de uma globulina progesterona (PBG); King e Tibbitts (1976) observando os grânulos presentes na subplacenta da chinchila, sugeriram que esses podiam estar relacionados às atividades secretoras.

Uhlendorf e Kaufmann (1979) sugeriram, num estudo da subplacenta da cobaia, que a degeneração que essa região sofria contemplava uma zona de demarcação ao despreendimento da placenta principal para o parto. Mess (2003), no petromus e no octodon, inferiu que poderia servir como uma região especial no crescimento do citotrofoblasto ou como um órgão de secreção endócrina, bem como de ou globulina ligadora de progesterona, embora a natureza dessa região fosse desconhecida. 


\section{MATERIAL E MÉTODOS}

4.1 Animais

Foram utilizadas oito pacas (Agouti paca) provenientes do pacário mantido pelo Setor de Animais Silvestres do Departamento de Zootecnia da Faculdade de Ciências Agrárias e Veterinárias de Jaboticabal - UNESP. A confirmação da prenhez foi realizada mediante sessões de ultra-sonografia $B$, usando-se transdutor bifreqüencial setorial eletrônico de 5,0 e 7,5 $\mathrm{MHz}^{\mathrm{b}}$ em modo para visualização do feto em estádio intermediário ou avançado de desenvolvimento.

Após constatação da prenhez no estágio desejado, as fêmeas foram mantidas em jejum de sólidos por um período de dez horas e jejum de líquidos por um período de seis horas que precederam as cirurgias para as coletas dos materiais.

\subsection{Colheita do Material}

Os procedimentos cirúrgicos foram realizados no Instituto de Obstetrícia e Reprodução do Departamento de Reprodução Animal da Faculdade de Ciências Agrárias e Veterinárias de Jaboticabal. A aplicação de tranqüilizantes, anestésicos, analgésicos e antibióticos, nas pacas, foi realizada sempre por via intramuscular, nos 
membros pélvicos. A tranqüilização foi obtida com azaperone ${ }^{c}$ na dose de $4 \mathrm{mg} / \mathrm{kg}$ de peso corporal. Após dez minutos, aplicou-se $0,06 \mathrm{mg} / \mathrm{kg}$ sulfato de atropina ${ }^{\mathrm{d}}$, seguindose, após o mesmo intervalo, a administração da associação de cloridratos de quetamina $^{e}(20 \mathrm{mg} / \mathrm{kg})$ e de xilazina ${ }^{f}(1,5 \mathrm{mg} / \mathrm{kg})$ para indução da anestesia. Realizou-se tricotomia abdominal ampla com lâmina de aço inoxidável, e a anestesia geral foi obtida mediante inalação por máscara de halotano juntamente com $750 \mathrm{~cm}^{3}$ de oxigênio puro por minuto.

A incisão da pele foi feita na linha média, sentido pré-retroumbilical, abrangendo cerca de 12 centímetros, devido ao considerável volume do corno uterino prenhe. O ovário foi identificado e, com o auxílio de duas pinças dente de rato colocadas no pedículo ovariano a um centímetro uma da outra, foi mantido suspenso e exteriorizado mediante incisão, procedendo-se, então, a sua ligadura. Duas outras pinças, iguais às anteriores, foram colocadas na porção inicial do corno uterino prenhe, incidindo-se entre as mesmas e removendo-se o corno em questão. Suturas tipo Schmieden (primeiro plano), e tipo Cushing (segundo plano), foram realizadas no útero, colocando-se o epíplon sobre a mesma ao final desse procedimento. A camada muscular foi suturada, utilizando-se ponto em X. Nas suturas do pedículo ovariano, do útero e da camada muscular, o fio categute cromado número $2^{\mathrm{h}} \mathrm{e}$, na sutura da pele, foi utilizado fio de náilon monofilamentado número $0^{\mathrm{h}}$.

aLabina- Agribands do Brasil Ltda

${ }^{\mathrm{b}}$ Pie Medical $\rightarrow$ LC 100 Vet Ltda

${ }^{\mathrm{c}}$ Stresnil $\rightarrow$ - Janssen Pharmaceutica

${ }^{\mathrm{d}}$ Sulfato de atropina $\rightarrow$ - Ariston Ltda

${ }^{\mathrm{e}}$ Ketamina $50 \rightarrow-$ Holliday - Scott S.A

\footnotetext{
Coopazine $\rightarrow$ - Coopers Brasil Ltda

${ }^{g}$ Halotano $\rightarrow$ - Cristália Produtos Químicos Farmacêuticos Ltda

${ }^{\mathrm{h}}$ Ethicon $\rightarrow$ - Ltda
} 
Imediatamente, após a cirurgia, foi realizado curativo local com solução de iodo a $2 \%$, colocado esparadrapo hipoalergênico' sobre a sutura de pele e aplicados antibióticos $^{\mathrm{j}}(15.000 \mathrm{U} / \mathrm{kg}$ de benzilpenicilina benzatina, $7.500 \mathrm{U} / \mathrm{kg}$ de benzilpenicilina procaína, $7.500 \mathrm{U} / \mathrm{kg}$ de benzilpenicilina potássica, $6,25 \mathrm{mg} / \mathrm{kg}$ de sulfato de diidroestreptomicina e $6,25 \mathrm{mg} / \mathrm{kg}$ de sulfato de estreptomicina) e 0,020 $\mathrm{mg} / \mathrm{kg}$ de buprenorfina' para analgesia. Depois de 48 horas, outra dose dos antibióticos foi administrada e o esparadrapo mantido até a retirada dos pontos da pele, ocorrida após sete dias de cirurgia (OLIVEIRA, 2004).

\subsection{Análise Macroscópica}

O corno retirado foi dissecado cuidadosamente, sendo o feto e as porções placentárias pesadas em balança analítica, medidas as dimensões com paquímetro e fotodocumentadas. 


\subsection{Processamento para Embebição em Parafina}

Os fragmentos das diversas áreas foram obtidos após dissecção cuidadosa do órgão e, em seguida, fixados por imersão em solução de formol $10 \%$ em tampão

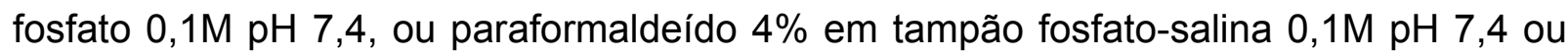
Bouin.

Após a fixação os fragmentos placentários foram submetidos aos procedimentos rotineiros de desidratação, diafanização e embebição em parafina contendo plastificante (Histosec $\rightarrow$, Brasil).

Cortes de $7 \mu \mathrm{m}$ cortes foram obtidos em micrótomo rotativo (Leica, RM2155) e coletados em lâminas histológicas previamente silanizadas.

Para avaliação da histoarquitetura geral dos fragmentos processados, os cortes foram desidratados e corados pelas técnicas de hematoxilina e eosina, tricrômicos de Masson e Gomori ou picrosirius. Os cortes corados foram montados em resina e analisados e documentados no fotomicroscópio (Nikon Eclipse E-800 e Leica DMR). 
4.5 Reações Citoquímicas e Imunocitoquímicas

4.5.1 Reação citoquímica de PAS (ácido periódico - Shiff)

Os cortes histológicos obtidos de acordo com o item 4 foram desparafinizados, hidratados e submetidos à reação de PAS com e sem tratamento prévio pela digestão de amilase $1 \%$ (Sigma St Louis, USA) por 30 min. a $37^{\circ} \mathrm{C}$. Após a reação, os cortes foram contra corados com hematoxilina e processados para montagem permanente em bálsamo do Canadá. As análises e fotodocumentações foram realizadas no microscópio de luz Nikon-Eclipse 800.

\subsubsection{Reações para Citoqueratina, Vimentina e PCNA}

Foram realizadas reações imunocitoquímicas utilizando-se os anticorpos anticitoqueratina policlonal de coelho (cód. PU071-UP, Biogenex), anti-vimentina policlonal de cabra (cód. SC-1226, Santa Cruz Biotechnology, USA) e anti-PCNA monoclonal de camundongos (cód.107904, Novocastra, UK). Como anticorpo secundário, foi utilizado, kit LSAB® - HRP Peroxidase (DAKO K0690 - Corporation, Carpinteria, EUA). Os cortes histológicos desparafinizados e hidratados foram equilibrados em tampão TRis-HCL

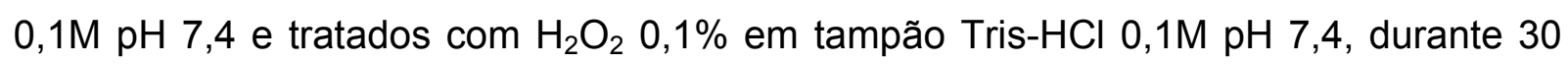


minutos a temperatura ambiente. Em seguida, os cortes foram tratados com tampão citrato $0,1 \mathrm{M} \mathrm{pH} \mathrm{6,0} \mathrm{e} \mathrm{irradiados} \mathrm{em} \mathrm{microondas} \mathrm{de} \mathrm{uso} \mathrm{caseiro} \mathrm{(Sanyo),} \mathrm{na} \mathrm{potência}$ máxima $(700 \mathrm{MHz})$ três vezes durante três minutos. Os cortes foram, em seguida, equilibrados em tampão fosfato-salina (PBS) $0,1 \mathrm{M} \mathrm{pH} 7,4$ e tratados com leite desnatado a 2\% em PBS por 20 minutos. As incubações com os anticorpos primários foram realizados em câmara úmida durante 12 horas à temperatura de $0-4^{\circ} \mathrm{C}$. Após esse período, os cortes foram lavados e incubados com os anticorpos secundários conjugados com peroxidase e revelados pelo sistema diaminibenzidina/ $\mathrm{H}_{2} \mathrm{O}_{2}$.em tampão tris- $\mathrm{HCl}$ pH 8,2. Os cortes foram contra corados com Hematoxilina de Harris e montados com resina sintética - Entellan (Merck, Darmstadt, Alemanha).

As análises e fotodocumentações foram realizadas no microscópio de luz NikonEclipse 800.

4.6 Processamento para Microscopia Eletrônica de Transmissão

As pequenas amostras placentárias foram fixadas em glutaraldeído 2,5\% (Polyscience Inc., USA) em tampão fosfato $0,1 \mathrm{M}$, pH 7,4, por no mínimo 24 horas, lavadas em tampão fosfato, pós-fixadas com tetróxido de ósmio 1\% (Polyscience, Inc. USA) em tampão fosfato $0,1 \mathrm{M}$ por uma hora e desidratadas em concentrações crescentes de etanol (70 a 100\%) e óxido de propileno (Polysciences, Inc., USA). Em seguida, os fragmentos foram embebidos em resina Spurr (Electron Microscopy Sciences, Co. USA e a polimerização induzida) à temperatura de $60^{\circ} \mathrm{C}$, por 72 horas. 
seguida, os fragmentos foram embebidos em resina Spurr (Electron Microscopy Sciences, Co. USA e a polimerização induzida) à temperatura de $60^{\circ} \mathrm{C}$, por 72 horas. Cortes semifinos destes materiais foram obtidos por meio de cortes em ultramicrótomo e corados com azul de toluidina para análise prévia, objetivando delimitar a região dos cortes ultrafinos. Cortes ultrafinos de $60 \mathrm{~nm}$ foram obtidos no ultramicrótomo (Leica ULTRA-CUT UCT ) e coletados em telas de cobre, posteriormente os cortes foram contrastados pelo acetato de uranila $2 \%$ (cinco minutos) e pelo citrato de chumbo $0,5 \%$ (dez minutos). As análises e documentações foram realizadas em microscópio eletrônico de transmissão - JEOL1010.

\subsection{Perfusão da Rede Vascular da Placenta}

\subsubsection{Injeção de Látex}

Uma placenta de paca no período final de prenhez foi perfundida por meio de injeções de látex-neoprene corado $^{1}$ através dos vasos umbilicais (artéria fetal em vermelho e veia fetal em amarelo) e dos vasos uterinos (artéria materna em branco e veia materna em verde). Após a injeção e a fixação da peça em solução de formol a 10\%, procedeu-se a dissecção para à análise macroscópica da disposição vascular.

Corante - Sulvinil - Glassurit do Brasil S/A

2Latex Neoprene 650 - Du Pont do Brasil 


\subsubsection{Injeção de Mercox}

Foram utilizadas duas placentas coletadas de pacas no período intermediário de prenhez, pela análise em ultra-som. A solução de monômero de metacrilato (Mercox - Vilene Hospital C L=2 Okenshji, Co., Ltda., Japão) foi adicionada à solução catalizadora, de acordo com as instruções do fabricante e realizou-se a injeção através dos vasos arteriais uterinos. Após a polimerização realizada à temperatura ambiente, as placentas foram lavadas em água destilada e, em seguida, imersas em solução de hidróxido de sódio $(\mathrm{NaOH}) 5-10 \%$, a $60^{\circ} \mathrm{C}$. Foram realizadas trocas periódicas da solução $\mathrm{NaOH}$ até a completa corrosão do material orgânico. Os moldes vasculares foram lavados com água destilada até a completa retirada do $\mathrm{NaOH}$ e secados em estufa a $37^{\circ} \mathrm{C}$. Posteriormente, os moldes vasculares foram incluídos em solução de gelatina incolor a $20 \%$, levados à geladeira para garantir maior resistência ao molde, e em seguida, obtidos pequenos fragmentos que foram novamente lavados em água corrente para retirada da gelatina. Após nova secagem em estufa, montaram-se os fragmentos selecionados em bases metálicas e procedeu-se à metalização com ouro utilizando o metalizador (EMITECH K550). As análises e documentações foram realizados no microscópio eletrônico de varredura (LEO 435 VP). 
Resultados 


\section{RESULTADOS}

\subsection{Análise macroscópica}

A placenta da paca (Agouti paca) plenamente formada tem um formato discóide, integra-se à parede uterina, formando uma protuberância discóide na sua base voltada para o feto, e o ápice está inserido na parede uterina através de um pedúnculo (Figuras 1A,B). Pelo corte sagital através da região mediana da placenta a termo podem-se identificar duas regiões distintas: a placenta principal, de tonalidade avermelhada, que ocupa a maior parte da base discóide, e a subplacenta de tonalidade esbranquiçada, ocupando o ápice do cone em íntimo contato com o tecido materno (Figuras 1 C,D).

Esse aspecto macroscópico é observado desde o terço médio de gestação da paca, porém as dimensões no terço médio com $1,5 \mathrm{~cm}$ de largura por 0,8 $\mathrm{cm}$ de altura são menores, se comparadas com as do terço final, quando podem atingir $2,0 \mathrm{~cm}$ de largura e $0,7 \mathrm{~cm}$ de altura. 
5.2 Análises em Microscopia de luz

Em cortes histológicos, a região da subplacenta pode ser facilmente distinguida da placenta principal e do tecido materno nos materiais coletados, tanto do terço final, quanto no terço médio da gestação. Em uma vista panorâmica (Figura 2), a subplacenta apresenta-se como uma região isolada delimitada na sua base pelo tecido mesenquimal de origem fetal contígua à da placenta principal (Figuras 3A,B). Nesse tecido mesenquimal foram constatados vasos de diferentes calibres, de parede delgada e revestida por endotélio. Lateralmente e no ápice, o perímetro da subplacenta é delineado por um tecido amorfo contíguo ao estroma endometrial, contendo resquícios de células degeneradas (Figura 3C). Nesse tecido de origem materna localizado lateralmente são encontrados freqüentemente vasos sangüíneos calibrosos, cujas paredes são destituídas de endotélio, mas revestidas de massas de células gigantes e/ou multinucleadas (Figura 3D).

A subplacenta apresenta-se como uma estrutura composta de projeções lamelares irregulares. O eixo dessas lamelas é constituído pelo tecido mesenquimal fetal contendo vasos sangüíneos do tipo venoso de pequeno calibre e de capilares sangüíneos (Figura 3E). Revestindo esse eixo de tecido mesenquimal encontra-se uma camada contínua de citotrofoblastos identificados por suas células de formato colunar, com núcleo esférico único e central. Acima dessa camada de citotrofoblasto, encontram-se as camadas de sinciciotrofoblasto identificadas como massas celulares multinucleadas (Figura 3F). 
No perímetro da subplacenta, observa-se o sinciciotrofoblasto em íntimo contado com tecidos de origem materna (Figura $3 C$ ), porém nas regiões mais internas da subplacenta do terço final da gestação, não é possível distinguir o tecido materno, sendo o espaço interlamelar ocupado predominantemente pela massa de sincíciotrofoblastos (Figuras 3E,F) entremeada por um material amorfo acelular. Nos materiais do terço médio da gestação, o espaço interlamelar é ocupado predominantemente pelo sinciciotrofoblasto, porém em algumas áreas pode-se notar, além do material amorfo, a presença de restos celulares de origem provavelmente materna. Nesses espaços interlamelares dos materiais observados de terços médio e final de gestação, não são constatadas estruturas que lembrem vasos sangüíneos.

A presença de células trofoblásticas não se restringe ao interior da subplacenta, cujo perímetro externo pode ser delineado pelo limite de extensão de suas lamelas. Pela análise histológica da interface com o endométrio, constata-se a presença de células trofoblásticas distribuídas profundamente no tecido endometrial.

Lateralmente à subplacenta, observam-se células trofoblásticas do tipo gigante multinucleadas isoladas ou em agregados espalhadas no tecido endometrial e junto aos vasos sangüíneos (Figuras 3C,D). Nesses vasos, freqüentemente repletos de sangue, observam-se redes de células gigantes delimitando, ou mesmo ocupando parcialmente a luz desses vasos. Sua parede apresenta organização atípica, não sendo possível, na maioria das vezes, distinguir se são vasos venosos ou artérias, devido à presença de grandes quantidades de células trofoblásticas gigantes, permeando essa parede (Figura 3D). O tecido endometrial apresenta-se pouco organizado, não sendo possível distinguir sua celularidade, sendo freqüente a presença de restos celulares distribuídos em meio a um estroma de aspecto amorfo. 
$\mathrm{Na}$ interface da região apical da subplacenta, verifica-se que, próximo ao perímetro das lamelas, encontram-se perfilados agregados descontínuos de células gigantes (Figura 4A). Os espaços entre esses agregados tornam-se cada vez mais amplos à medida que se afastam do perímetro da subplacenta. Freqüentemente junto a esse agregado de células trofoblásticas, é encontrado sangue extravasado, porém sem qualquer vestígio que lembre um vaso sangüíneo (Figura 4B). Estruturas que lembram vasos sangüíneos são encontradas em áreas mais distantes do perímetro da subplacenta, porém suas paredes encontram-se totalmente desorganizadas pela infiltração de células trofoblásticas gigantes, assim como pela ausência de revestimento endotelial, que são substituídos por uma rede de células trofoblásticas gigantes multinucleados (Figuras 4C,D). Ao longo dessa extensão do endométrio onde são encontrados agregados de células trofoblásticas gigantes, verifica-se que o tecido endometrial está comprometido com extensas áreas contendo células degeneradas, extravasamento sangüíneo, vasos sangüíneos cujas paredes estão comprometidas com invasão de trofoblastos gigantes e, apenas nas regiões próximas aos grandes vasos, é possível identificar algumas células deciduais íntegras.

Em preparados histológicos corados pela técnica de picrosirius, distinguem-se um limite bem delineado do endométrio comprometido e do endométrio íntegro (Figura 5A). Este é identificado pela população de células deciduais formando uma espessa camada até junto ao perimétrio (Figura 5B). Nesse endométrio decidualizado, não são identificadas células com fenótipo de trofoblastos, e os vasos sangüíneos apresentam sua parede tanto com o revestimento endotelial quanto a túnica média normais (Figura 5C). O perimétrio apresenta uma delgada camada de células musculares lisas, e os vasos sangüíneos contidos nessa camada, assim como os vasos presentes no 
pedúnculo que se conectam ao mesométrio, apresentam revestimentos normais (Figura $5 D)$.

5.3 Citoquímica e Imunocitoquímica

5.3.1 - Reação de PAS e Alcian Blue

A reação de PAS (Ácido Periódico de Shiff) realizada na amostra de subplacenta dos terços médio e final de gestação apresenta marcação fraca ou ausente para o citotrofoblasto, enquanto a massa de sinciciotrofoblasto apresenta marcação positiva (Figura 6A), com redução de intensidade pela ação prévia da amilase. Notadamente a massa amorfa que entremeia o sinciciotrofoblasto apresenta intensa reação PAS positiva amilase resistente (Figura 6B), evento semelhante ao observado nas células gigantes localizadas próximas à subplacenta em seus limites basal e lateral (Figura 6C).

A reação citoquímica com Alcian Blue pH 2,5 apresenta reação fracamente positiva junto à massa celular sincicial das lamelas da subplacenta (Figura 6D) e nos agregados de células trofoblásticas gigantes próximas a subplacenta nas amostras do terço médio da gestação e, ausente em seu terço final. 


\subsection{2 - Reações para Citoqueratina, Vimentina e PCNA}

A imunocitoquímica para citoqueratina apresenta intensa reação positiva para células localizadas no interior da placenta, na subplacenta e nos agregados celulares distribuídos junto ao tecidos endometriais localizados nas regiões de interface com a subplacenta e, na parede dos vasos sangüíneos localizados nesse endométrio.

$\mathrm{Na}$ subplacenta, a reação é positiva para os citotrofoblastos e os sinciciotrofoblastos das lamelas (Figura 7A) e, com menor intensidade, para as células gigantes localizadas na região mais externa das lamelas da subplacenta, e negativo para a massa amorfa (Figura 7B). Os agregados celulares citoqueratina positivos localizados no tecido endometrial, assim como aquela que reveste a luz dos vasos sangüíneos presentes no endométrio próximos das interfaces apical e lateral da subplacenta, consistem essencialmente de células trofoblásticas gigantes e/ou de massas sinciciais de trofoblasto. As paredes dos vasos sangüíneos maternos de maior calibre apresentam extensas áreas com infiltrações de células citoqueratina positivas (Figuras 7C,D).

A vimentina apresenta intensa reação positiva junto ao revestimento endotelial dos vasos sangüíneos distribuídos no interior da placenta principal e da subplacenta. Nesses preparados, confirma-se a rede vascular que acompanha o tecido mesenquimal do eixo central das lamelas da subplacenta constituído essencialmente de vasos sangüíneos do tipo venoso e de capilares, não sendo constatados vasos do tipo arterial (Figura 7E). Não se verifica reação positiva para vimentina junto à parede dos leitos vasculares que permeiam o tecido materno da interface subplacenta-endométrio (Figura 
7F). Esse padrão de reatividade para vimentina não apresenta variações entre os terços médio e final da gestação.

A reação de PCNA (proliferating cell nuclear antigen) apresenta reatividade positiva junto ao citotrofoblasto das lamelas da subplacenta do terço médio de gestação e em algumas células do sincicio (Figura 8A), assim como, em algumas células trofoblásticas gigantes distribuídas no estroma endometrial e junto à parede dos vasos maternos. No terço final de gestação, verificam-se marcações positivas junto aos núcleos das células citotrofobláticas das lamelas da subplacenta, porém em proporções reduzidas, se comparadas com as do terço médio de gestação (Figura 8B). Raras células sinciciais e trofoblastos gigantes apresentam reação PCNA positiva em seus núcleos no terço final da gestação.

\subsection{Microscopia Eletrônica de Transmissão da Subplacenta}

A ultra-estrutura da subplacenta identifica a existência de duas populações trofoblásticas distintas distribuídas nas paredes das lamelas. O eixo das lamelas é constituído por um tecido cuja matriz extracelular é pouco preservada nesses preparados, fenômeno típico do tecido conjuntivo mesenquimal (Figura 9A). Nesse tecido estão presentes os vasos sangüíneos de pequeno calibre, na sua grande maioria vênulas e capilares (Figura 9B). Apoiado na lâmina basal que separa o eixo de mesênquima fetal, estão as células citotrofoblásticas, identificadas como células contendo um citoplasma finamente granular, com a presença de poucas mitocôndrias, retículo endoplasmático rugoso pouco desenvolvido e um núcleo esférico e com grumos 
de cromatina condensada, distribuída uniformemente. Ao lado dessas células, era freqüente encontrar outras com o citoplasma extraído, destituído da maioria das organelas e o núcleo com condensações cromatínicas irregulares (Figura 9C). Essas células citotrofoblásticas apresentam junções celulares do tipo adesivas e desmossomas, unindo células contíguas laterais e também células dos estratos acima que mantinham junções com as células sinciciais. Essas células unidas por junções delimitam espaços intercelulares irregulares e,nessas superfícies livres do citotrofoblasto, apresentam pequenos prolongamentos citoplasmáticos que unem uma célula à outra (Figura 9D). Essas estratificações de células do tipo citotrofoblasto são observadas com maior freqüência nas amostras do terço médio de gestação, enquanto, no terço final, era mais comum observar monocamadas de células citotrofoblásticas em continuidade com células sinciciais. Constata-se também que, no terço final da gestação, é mais freqüente a incidência de citotrofoblastos com o citoplasma extraído e núcleo com condensações irregulares, lembrando características ultra-estruturais de células comprometidas pela apoptose.

A massa de células sinciciais ao redor das lamelas é facilmente identificada pela presença de vários núcleos no seu interior, como também pela presença de grânulos eletrondensos de contorno irregular, envoltos por uma membrana, em meio ao citoplasma finamente granular contendo glicogênio (e áreas de extração desse glicogênio), mitocôndrias, retículo endoplasmático granular e complexo de Golgi (Figura 
10A). Ao longo de toda a superfície livre do sinciciotrofoblasto que delimita os espaços, ou seja, na camada mais próxima aos citotrofoblastos, podem também ser distinguidos pelas características citadas anteriormente, e pela presença de projeções citoplasmáticas semelhantes a microvilos curtos e irregulares. Fazendo contato com elementos do estroma endometrial, também se observam microvilosidades curtas em profusão (Figura10B). Nas lacunas e nos espaços intercelulares formados entre os sinciciotrofoblastos, são encontrados restos celulares do estroma endometrial, entre os quais, um material amorfo eletron-denso semelhante àquele encontrado no interior dos sinciciotrofoblatos. No terço médio da gestação, é possível encontrar nessas lacunas restos de células degeneradas, mas, no terço final esse material confinado é constituído de um material amorfo de diferentes eletrondensidades (Figuras 10B,C,D,E,F).

Nas lamelas localizadas no perímetro da região apical da subplacenta, as células sinciciotrofoblásticas estão conectadas a uma população celular de trofoblasto com características morfológicas próprias (Figura 11A). Essas células são multinucleadas e mantêm inicialmente o formato colunar ou poligonal e apresentam espessamento no perímetro celular com agrupamento de feixes de filamentos notadamente do tipo intermediário (Figura 11B). Essas formações delineiam o limite celular, dificultando até mesmo a identificação da membrana plasmática. Essas células, à medida que se afastam do perímetro, tornam-se maiores e constituem as populações de células trofoblásticas gigantes, que, além de multinucleadas, caracterizam-se pelo citoplasma contendo grânulos de glicogênio e espaços citoplasmáticos vazios decorrentes da extração do glicogênio, mitocôndrias e retículo endoplasmático rugoso esparso e fagossomas contendo resíduos parcialmente digeridos (Figuras 11C,D). 
No endométrio próximo à subplacenta, notaram-se células trofoblásticas entremeadas ao tecido endometrial com sinais de degeneração avançada, inseridas numa massa amorfa composta de tecido materno de, cujas células não se consegue identificar o conteúdo citoplasmático. Nessas áreas, pode-se encontrar sangue extravasado e células sinciciais. A constituição do leito vascular invadido, acompanhando o revestimento de alguns vasos, é realizada por uma célula sincicial única (Figura 12A), e em vasos de paredes mais espessas, contata-se a presença de células trofoblásticas gigantes (Figura 12B). Células trofoblásticas gigantes são encontradas com freqüência em meio ao tecido endometrial degenerado que apresenta células sangüíneas aparentemente extravasados, por não apresentarem organizações que lembrem vasos sangüíneos (Figura 12C).

\subsection{Vascularização da Subplacenta}

Pela observação macroscópica do molde vascular da subplacenta perfundida pelos vasos fetais, no terço intermediário de gestação, nota-se um ramo vascular de maior calibre que se insere perpendicularmente na base da subplacenta a partir da região central da placenta principal, acompanhado por outros vasos periféricos de menor calibre que se inserem ao longo da base da subplacenta (Figura 13A).

A perfusão vascular materna e fetal da placenta da paca em final de gestação com látex colorido permite observar que a subplacenta apresenta apenas uma tonalidade, isto é, a cor vermelha referente à perfusão via artéria fetal (Figura13B).

Pela microscopia eletrônica de varredura, observa-se que o ramo vascular que se insere centralmente na base da subplacenta, já próxima a esta, forma dois ramos e a 
partir deste subdivide-se em vários outros (Figuras 14A,B). Uma intrincada rede de delgados ramos permeia integralmente o interior da subplacenta, sendo difícil acompanhar sua trajetória completa. A impressão dos elementos presentes na parede dos vasos sobre as superfícies dos moldes vasculares mostra núcleos alongados, típicos de arteríolas (Figura 14C) e áreas de estrangulamento, possivelmente representativo das válvulas controladoras de fluxo sangüíneo presentes nas entradas do sistema capilar. Por essa técnica, verifica-se que as paredes desses capilares

apresentam revestimento contínuo (Figura 14D). 
Figura 1- Aspecto macroscópico da placenta da paca

A) Fotografia do local de inserção da placenta na parede uterina dissecada e recortada (linha --), face da serosa da parede uterina (UTs), placenta $(P)$, cordão umbilical (CU).

B) Fotografia da vista intraluminal da inserção da placenta no útero, face luminal da parede uterina (UTi), pedúnculo (seta), subplacenta $(\mathrm{S})$, placenta $(P)$, cordão umbilical (CU).

C) Corte sagital através da região mediana. Notar a presença da subplacenta (S) de cor esbranquiçada localizada no ápice da placenta principal $(P)$ em íntimo contato com o útero (UT). Atravessando a placenta principal encontra-se um vaso (seta) proveniente do cordão umbilical (CU).

D) Esquema do corte sagital através da região mediana baseada na fig $1 \mathrm{C}$. Subplacenta $(\mathrm{S})$, placenta principal $(\mathrm{P})$, parede do útero (UT), vaso (seta) proveniente do cordão umbilical (CU) percorrendo a região mediana da placenta principal. 

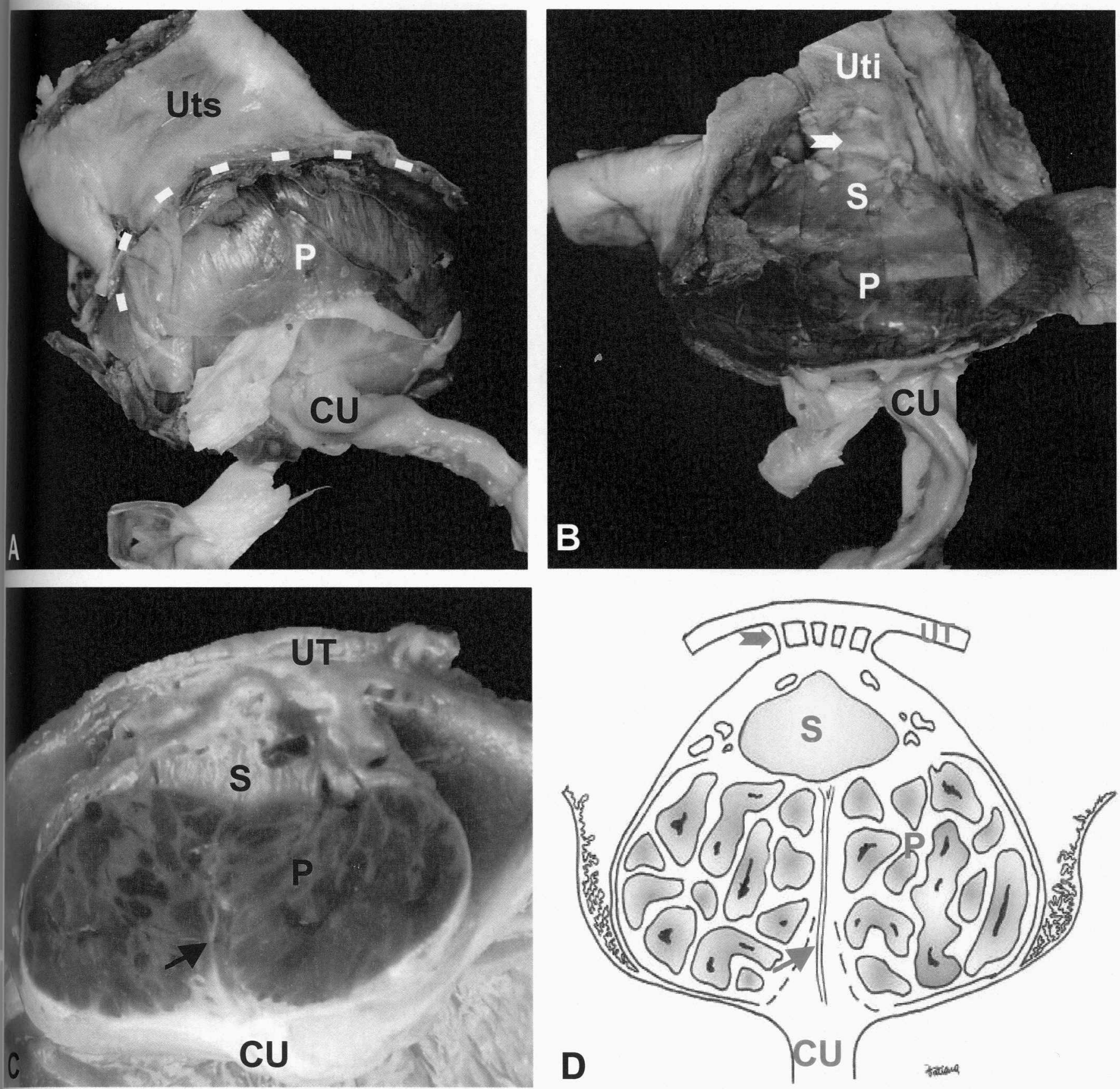
Figura 2 - Fotomicrografia panorâmica da subplacenta da paca no terço médio de gestação em plano de corte sagital, apresentando as interfaces do perímetro da subplacenta (S) com o endométrio (EC) e placenta principal $(\mathrm{P})$

A subplacenta (S) é constituída de agregados de lamelas em área delimitada pelo endométrio (EC) em sua maior extensão e na base pela placenta principal $(P)$. Neste endométrio são encontrados grupos de células trofoblásticas (Tf) e vasos sanguíneos amplos $(\mathrm{V})$, cujas paredes estão invadidas pelas células trofoblásticas (Tf). O tecido endometrial nestas regiões é constituído na sua grande extensão por um de tecido amorfo $(\bullet)$ e degenerado. H.E. 


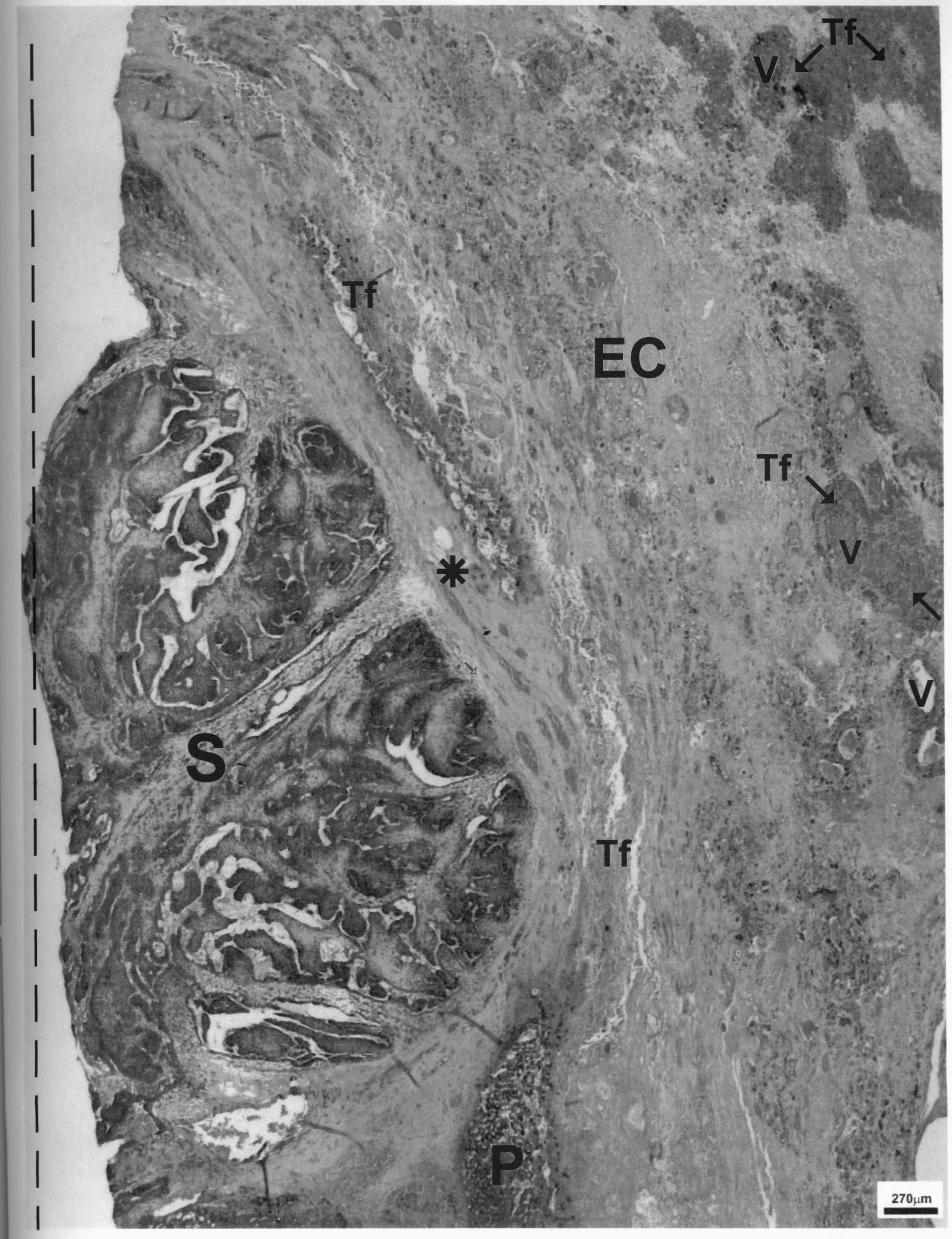


Figura 3 - Fotomicrografias em detalhe da subplacenta da paca no terço médio de
gestação

A) Região da interface entre a subplacenta (S) e a placenta principal (P), separada pela Zona transicional $(\mathrm{Zt})$ constituída de tecido mesênquimal fetal. Notar a organização lamelar no interior da subplacenta e uma parte de um lóbulo da placenta principal. Tric. Masson. $1 \mathrm{~cm}=375 \mu \mathrm{m}$

B) Detalhe da zona transicional, evidenciando a presença de pequenos vasos (cabeça de seta) no tecido mesenquimal que penetra no interior das lamelas da subplacenta (S). Tric. Masson. $1 \mathrm{~cm}=35,7 \mu \mathrm{m}$

C) Detalhe do perímetro da subplacenta (S) em contato com o endométrio (E). Nesta área juncional as lamelas da subplacenta entra em íntimo contato com o endométrio, o qual apresenta-se como um tecido amorfo, onde as células em avançado estado de degeneração não permitem a sua identificação (๑). H.E. $1 \mathrm{~cm}=66,7 \mu \mathrm{m}$

D) Detalhe da figura anterior. O tecido endometrial comprometido $(\bullet)$ apresenta vasos sanguíneos destituídos de revestimento endotelial e substituídas por células trofoblásticas $(\uparrow)$. Notar a presença de grupos de células trofoblásticas gigantes $(G)$ entre $o$ vaso e as células trofoblásticas de uma lamela da subplacenta (S). Tric. Masson. $1 \mathrm{~cm}=17,5 \mu \mathrm{m}$

E) Detalhe da organização lamelar ( $L$ ) da subplacenta, com o seu eixo constituído de tecido conjuntivo mesenquimal de origem fetal $(M)$ e pequenos vasos sanguíneos (V). Apoiado neste eixo de mesênquima encontra-se o arranjo epitelial de células citotrofoblásticas (seta) que continua com 0 sinciciotrofoblasto $\left({ }^{*}\right)$. HE $1 \mathrm{~cm}=17,5 \mu \mathrm{m}$

F) Detalhe de uma lamela com o seu eixo de tecido mesenquimal fetal (M) e capilares (V). Os citotrofoblastos (Ct) apoiam-se no tecido mesenquimal em arranjo epitelial contínuo e mais externamente os sincíciotrofoblastos (St). Tric. Gomori. $1 \mathrm{~cm}=7,5 \mu \mathrm{m}$ 

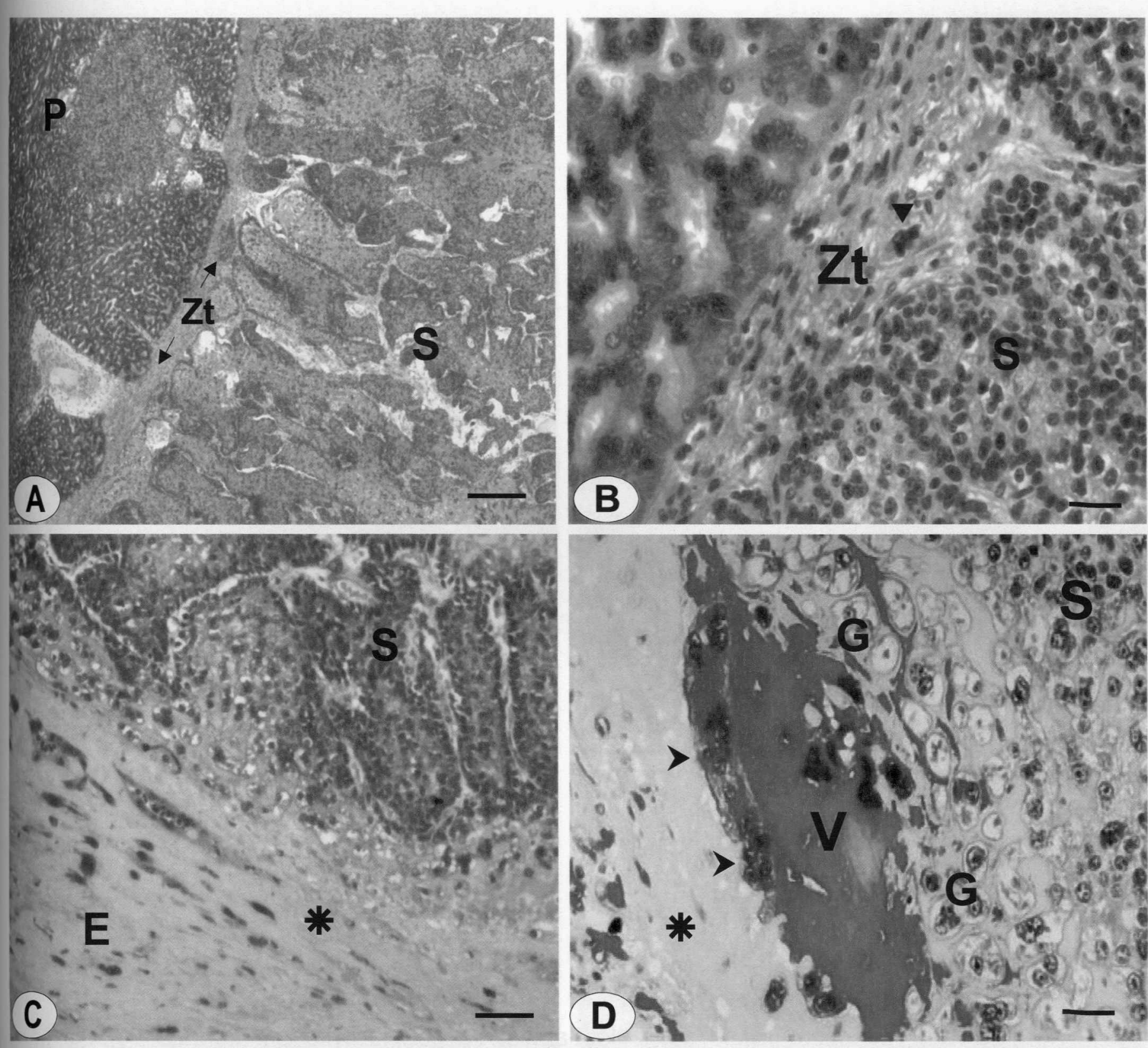

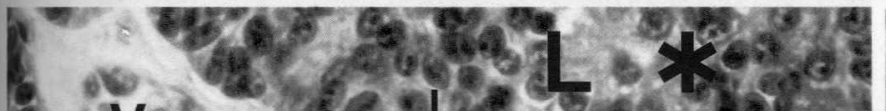

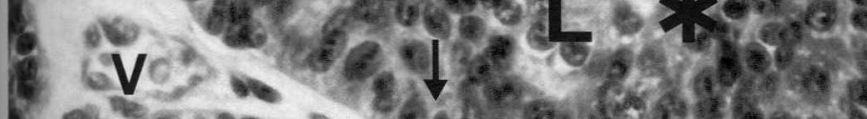

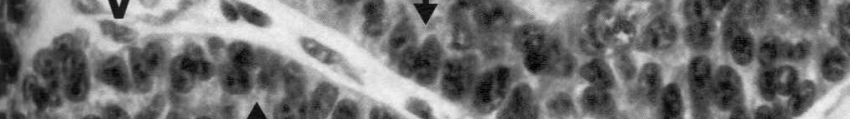
pol of

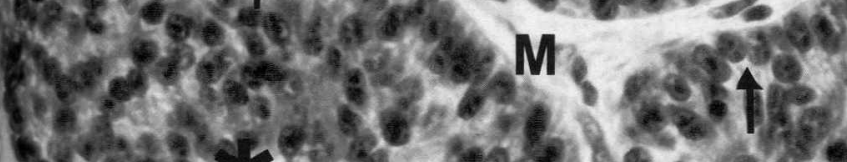
Exita

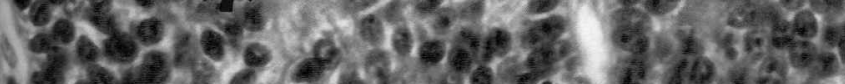

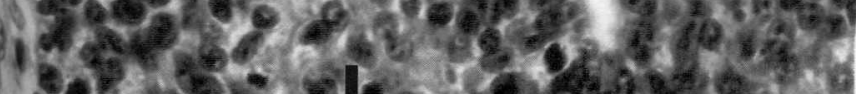
Q.e

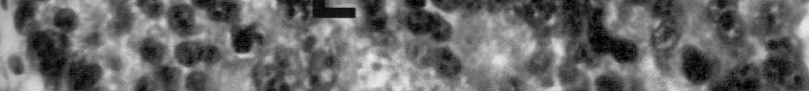

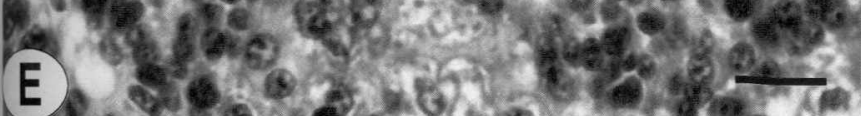

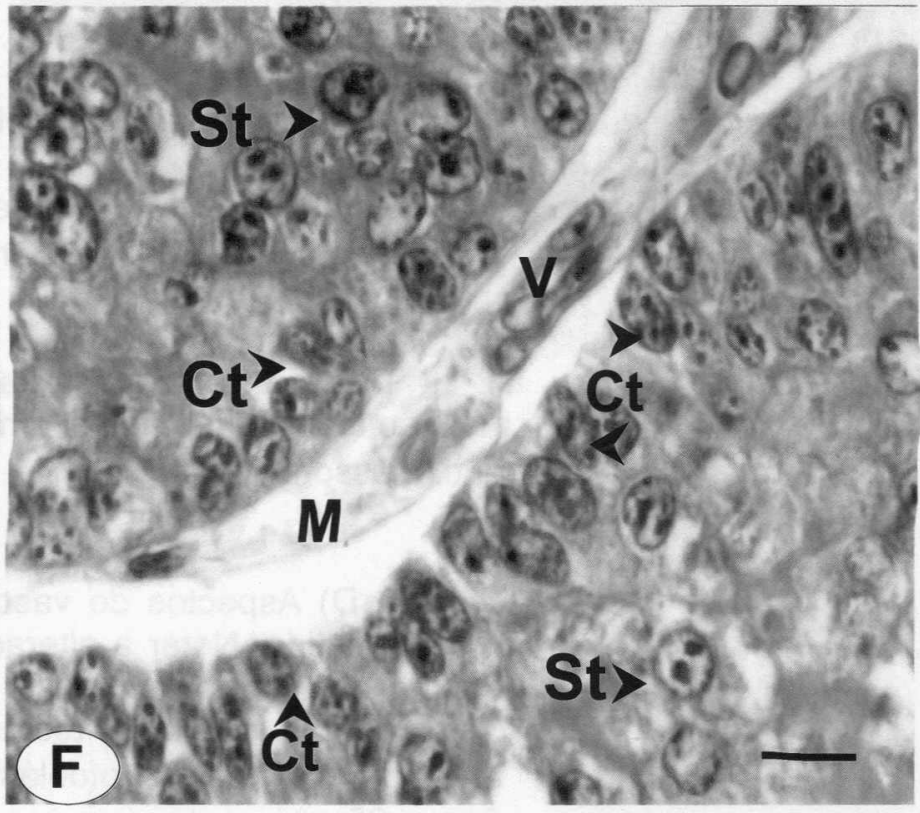


Figura 4 - Fotomicrografias da região apical da subplacenta em contato com o endométrio

A) Notar os grupos de células trofoblásticas gigantes (G) próximo a um vaso sanguíneo materno $(\mathrm{V})$ e a interposição de uma camada de tecido endometrial amorfo ( ) entre o trofoblasto gigante e os trofoblastos das lamelas da subplacenta (S). Tric. Masson. $1 \mathrm{~cm}=71 \mu \mathrm{m}$

B) Detalhe de um agregado de células trofoblásticas gigantes ( $G$ ) em meio ao tecido endometrial amorfo ( ) que contem sangue extravasado (Sg). Tric. Masson. $1 \mathrm{~cm}=7,5 \mu \mathrm{m}$

C) , D) Aspectos de vasos sanguíneos (V) encontrados no endométrio comprometido. Notar a alteração na parede dos vasos onde o revestimento endotelial de qualquer vaso sanguíneo materno é substituído por células trofoblásticas sinciciais (setas) e, nos vasos arteriais, a túnica média é infiltrada por células trofoblásticas gigantes $(\mathrm{G})$. HE. C $-1 \mathrm{~cm}=67 \mu \mathrm{m} ; \mathrm{D}-1 \mathrm{~cm}=25 \mu \mathrm{m}$ 

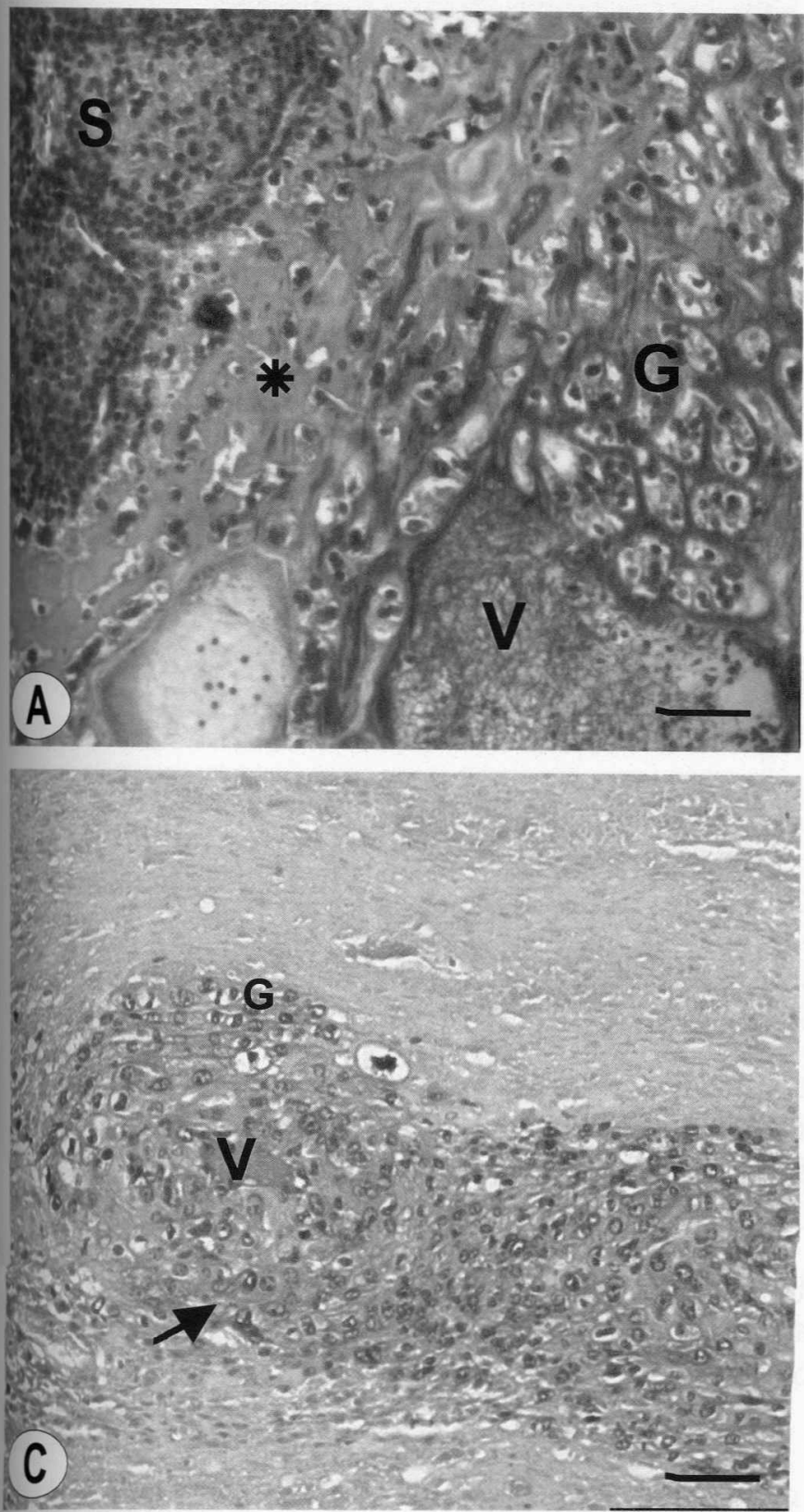

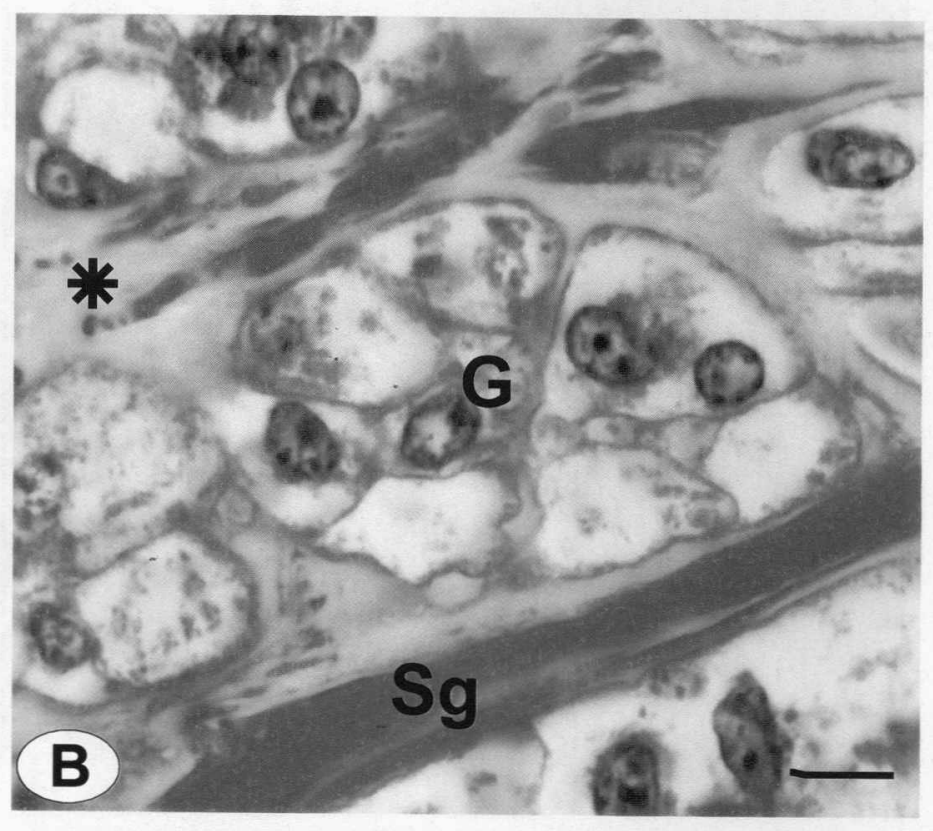

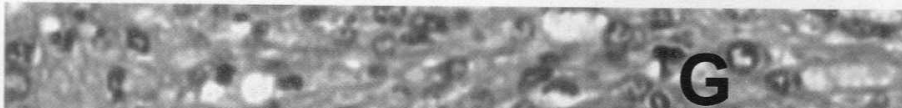

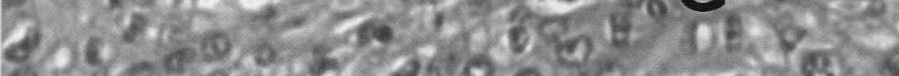

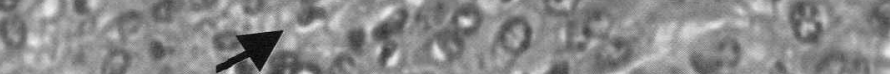

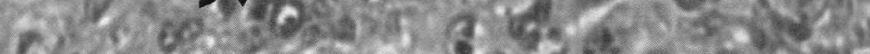

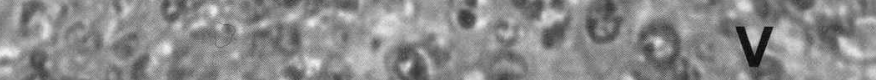

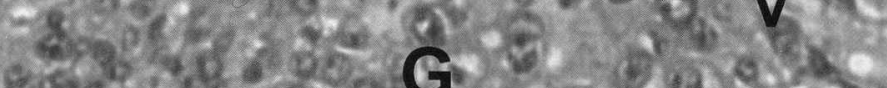

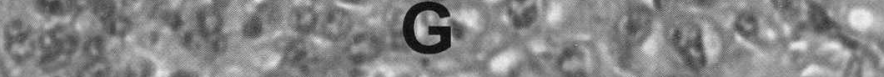

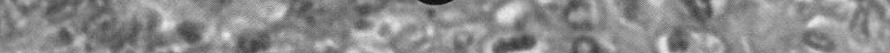

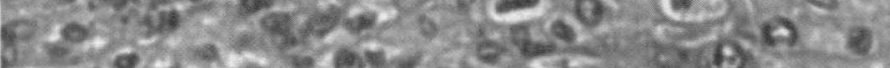

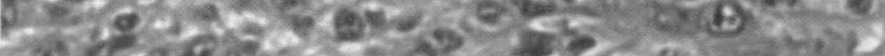

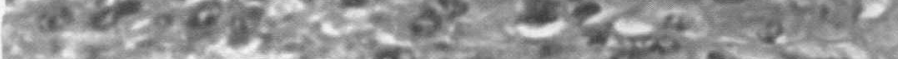

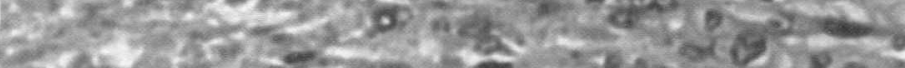

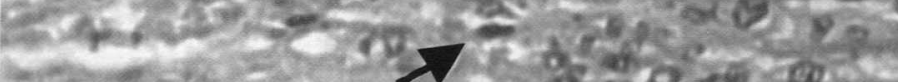

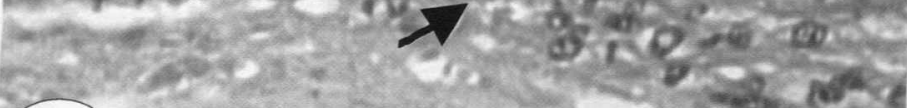

(D) $x^{-2}$ is ${ }^{2}=0$ 
Figura 5 - Fotomicrografias da região próxima ao miométrio e perimétrio do útero da paca no terço médio da gestação corado pela técnica de picrosirius

A) Região do endométrio distante da subplacenta mostrando a existência de um limite (seta) entre o endométrio decidualizado íntegro (EI) e o comprometido pela invasão do trofoblasto $(\mathrm{Ec}) .1 \mathrm{~cm}=250 \mu \mathrm{m}$

B) Região do miométrio $(\mathrm{Mi})$ e perimétrio $(\mathrm{Pm})$ junto ao pedúnculo $(\mathrm{Pd})$ que contêm os vasos oriundos do mesométrio. Os tecidos destas regiões não apresentam qualquer alteração ou comprometimento. $1 \mathrm{~cm}=250 \mu \mathrm{m}$

C) Detalhe de um vaso sanguíneo arterial (V) com endotélio normal (seta) presente no endométrio decidualizado (D) íntegro. $1 \mathrm{~cm}=24 \mu \mathrm{m}$

D) Detalhe de um vaso sanguíneo arterial $(V)$ presente no pedúnculo com o endotélio e demais túnicas de revestimento normais (seta). $1 \mathrm{~cm}=24 \mu \mathrm{m}$ 


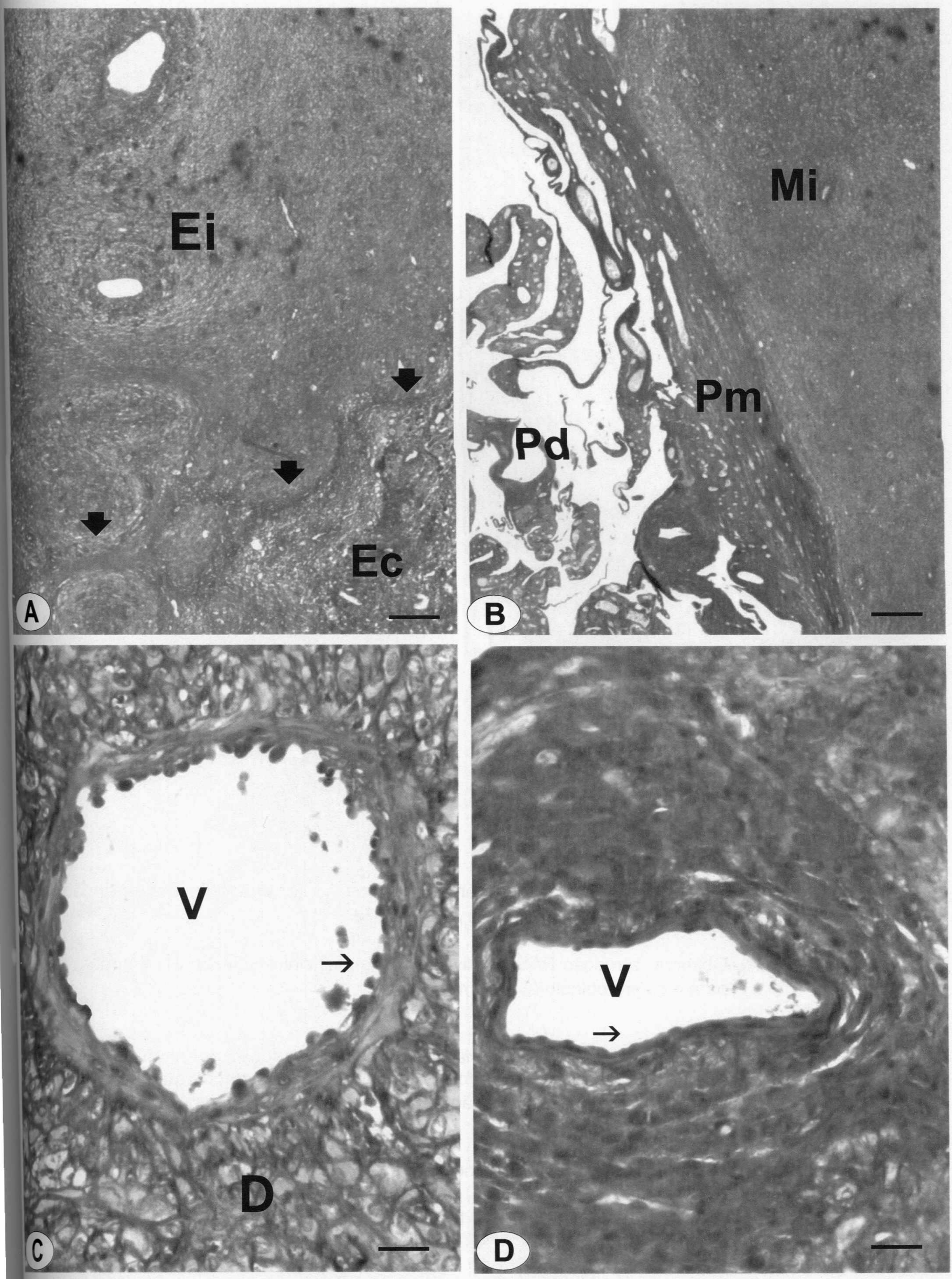


Figura 6 - Fotomicrografias da subplacenta da paca no terço médio de gestação coradas pela técnica de PAS e Alcian Blue

A) Observar a reação PAS positiva para e o sincíciotrofoblasto (St) e negativa para o citotrofoblasto $(\mathrm{Ct}) .1 \mathrm{~cm}=46 \mu \mathrm{m}$

B) Com o tratamento prévio pela amilase, ocorre redução da intensidade da reação positiva no sinciciotrofoblasto, porém a massa amorfa que entremeia o sincício (St) mantêm a reação positiva ao PAS. $1 \mathrm{~cm}=24 \mu \mathrm{m}$

C) O tecido amorfo que entremeiam as células gigantes (G) localizadas no perímetro da subplacenta (S) apresentava reação positiva ao PAS mesmo após o tratamento enzimático pela amilase. $1 \mathrm{~cm}=24 \mu \mathrm{m}$

D) A massa sincicial (St) apresenta fraca reação positiva ao Alcian Blue. $1 \mathrm{~cm}=$ $24 \mu \mathrm{m}$ 

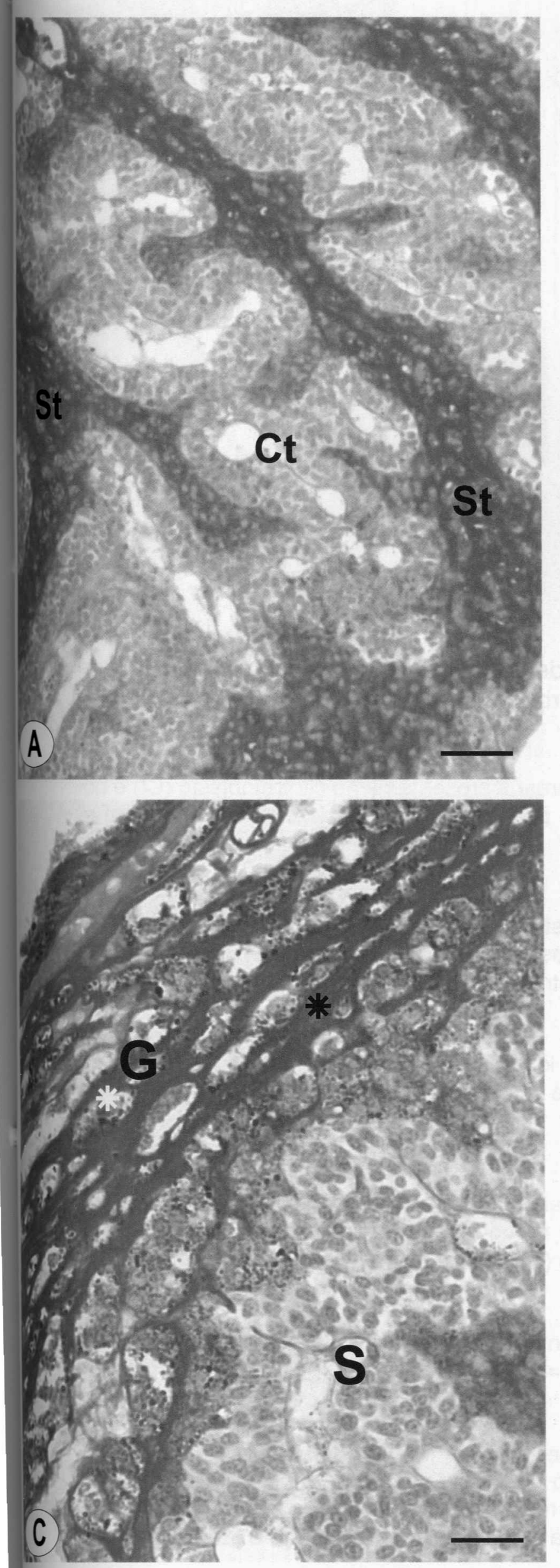

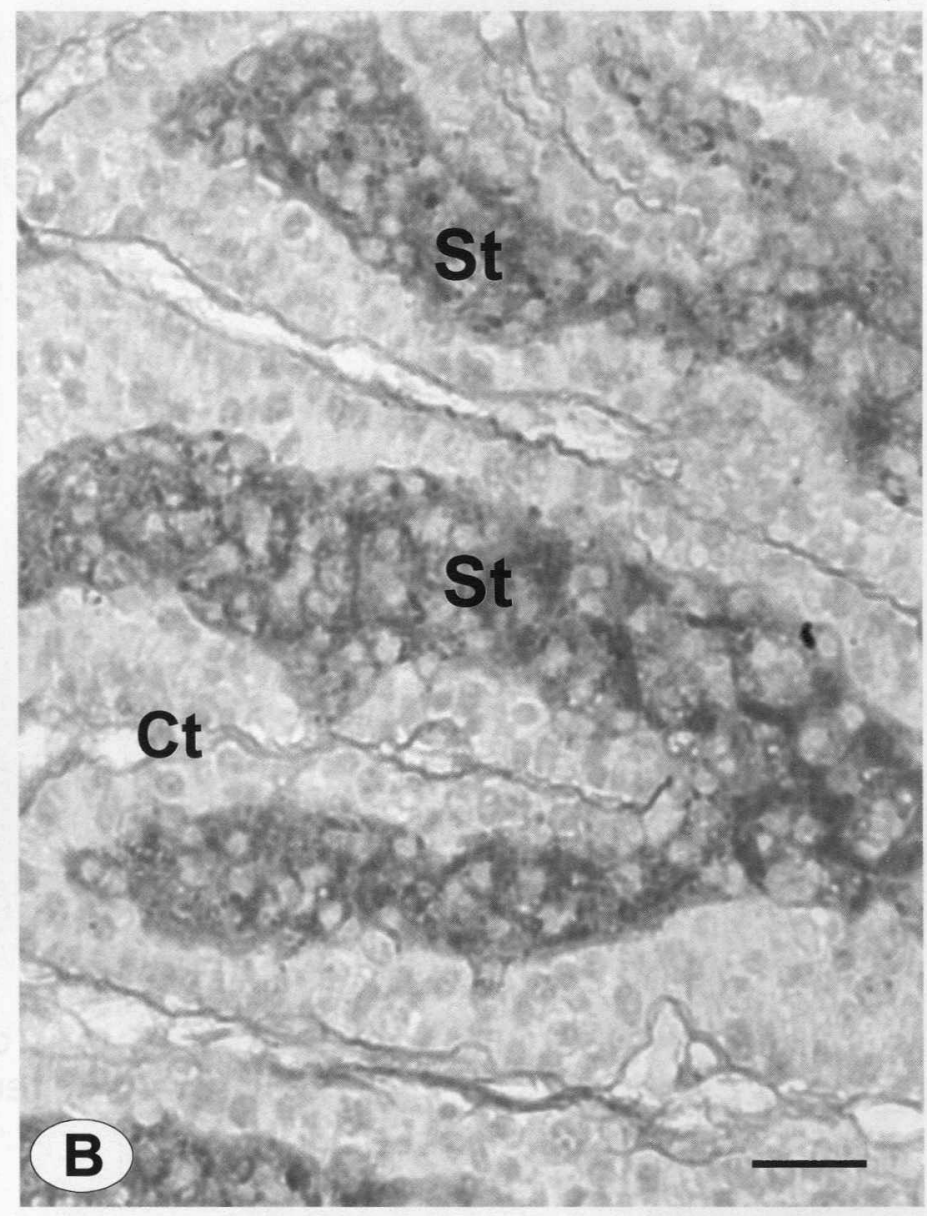

\section{St}

D 
Figura 7 - Fotomicrografias das reações de imunoperoxidase para citoqueratina e vimentina na subplacenta do terço final da gestação.

A) A reação positiva para citoquratina presente na no citotrofoblasto (Ct) e no sincício (St) da subplacenta, porém negativa no mesênquima $(\mathrm{M}) .1 \mathrm{~cm}=$ $23 \mu \mathrm{m}$

B) Detalhe do anterior mostrando reação positiva especifica para citoqueratina no citotrofoblasto (Ct) e no sincício (St) e, ausência nos interstícios do $(\bullet)$ sinciciotrofoblasto. $1 \mathrm{~cm}=56 \mu \mathrm{m}$

C) Os vasos maternos (V) localizados no endométrio comprometido apresentam revestimento de células positivas a citoqueratina (seta). $1 \mathrm{~cm}=72 \mu \mathrm{m}$

D) Detalhe do anterior mostrando reação positiva nos prolongamentos citoplasmáticos das células trofoblásticas (seta) que revestem a parede do vaso sanguíneo materno $(\mathrm{V}) .1 \mathrm{~cm}=12 \mu \mathrm{m}$

E) Reação positiva para vimentina nos vasos fetais (V) encontrados no interior a subplacenta. $1 \mathrm{~cm}=36 \mu \mathrm{m}$

F) Reação negativa para vimentina na parede de um vaso sanguíneo materno (V) encontrados no endométrio comprometido em área próxima à subplacenta. Notar a reação positiva nos vasos presentes no mesênquima das lamelas da subplacenta (seta). $1 \mathrm{~cm}=67 \mu \mathrm{m}$ 

की - 0 x 51.5 S $5 \mathrm{C}^{3}$ - atr.

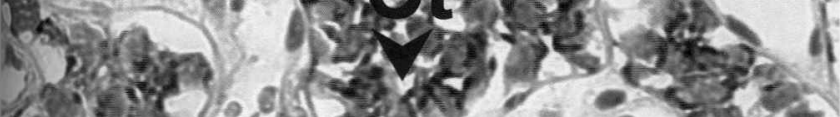
2. co. -...... (2) $m$. $-3+.2 .4$ , 2 , ... 4 A 35 .

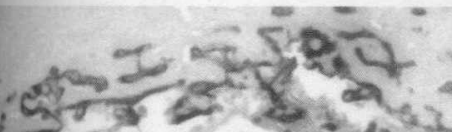

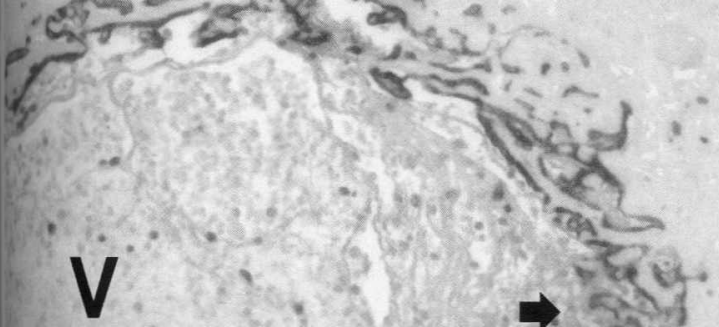

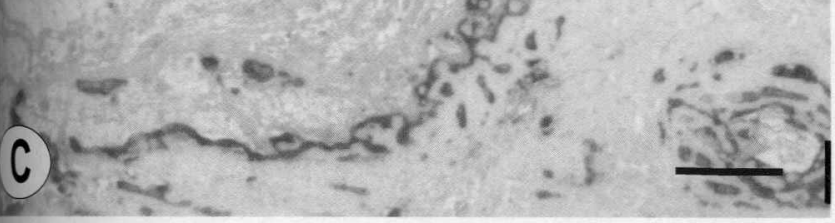

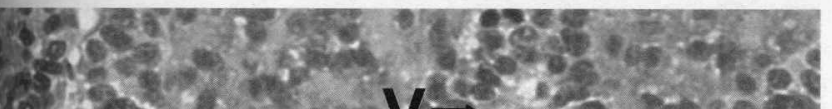

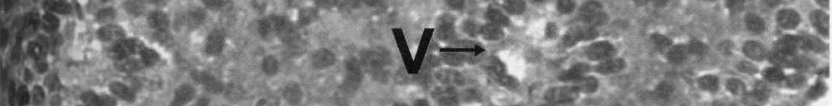

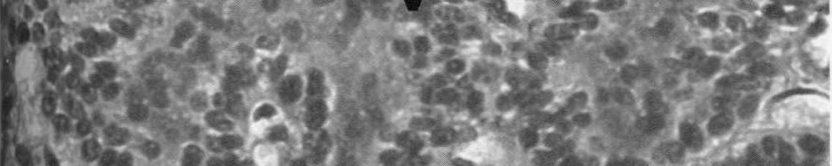

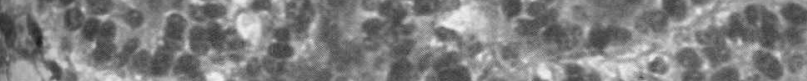

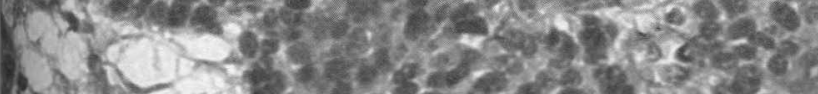
W.

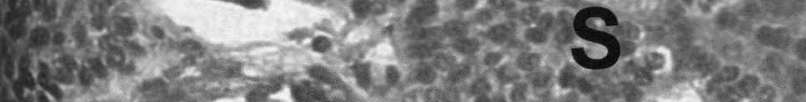

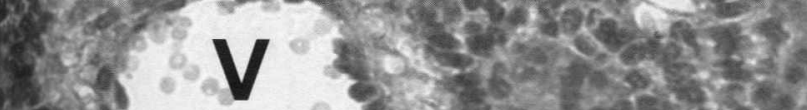

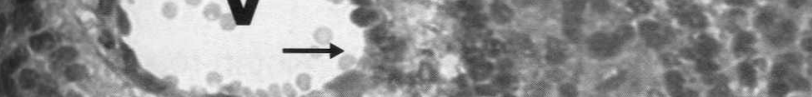

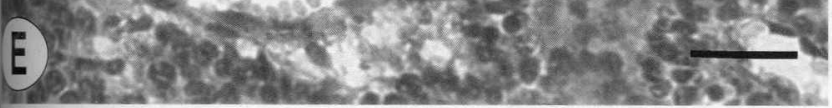
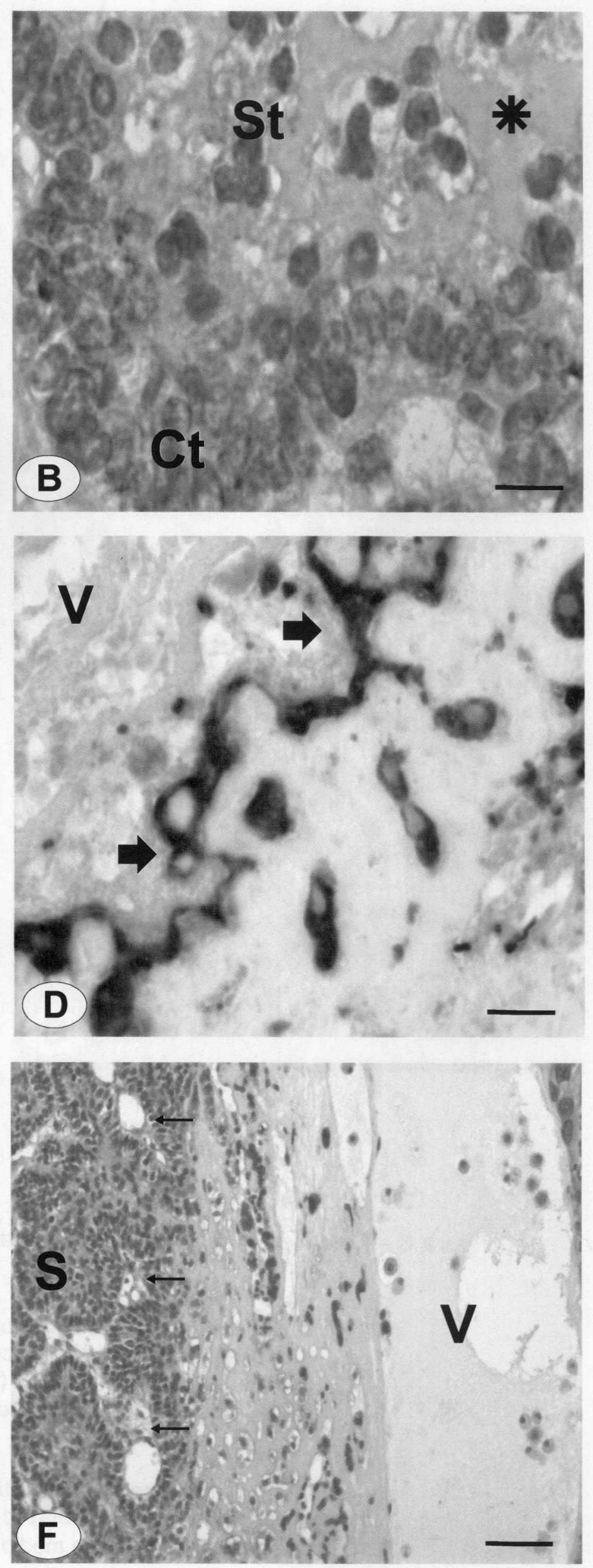
Figura 8 - Fotomicrografias da subplacenta da paca submetida à reação de PCNA.

A) Observar a reação positiva nos núcleos (seta) das células do citotrofoblasto (Ct) das lamelas da subplacenta no terço médio da gestação. Algumas poucas células do sincício (St) apresentam também marcação positiva (cabeça de seta) ao PCNA. $1 \mathrm{~cm}=22 \mu \mathrm{m}$

B) Idem anterior na subplacenta do terço final de gestação. Notar reação positiva no núcleo (seta) de poucas células citotrofoblásticas (Ct) se comparada ao do terço médio. $1 \mathrm{~cm}=22 \mu \mathrm{m}$ 

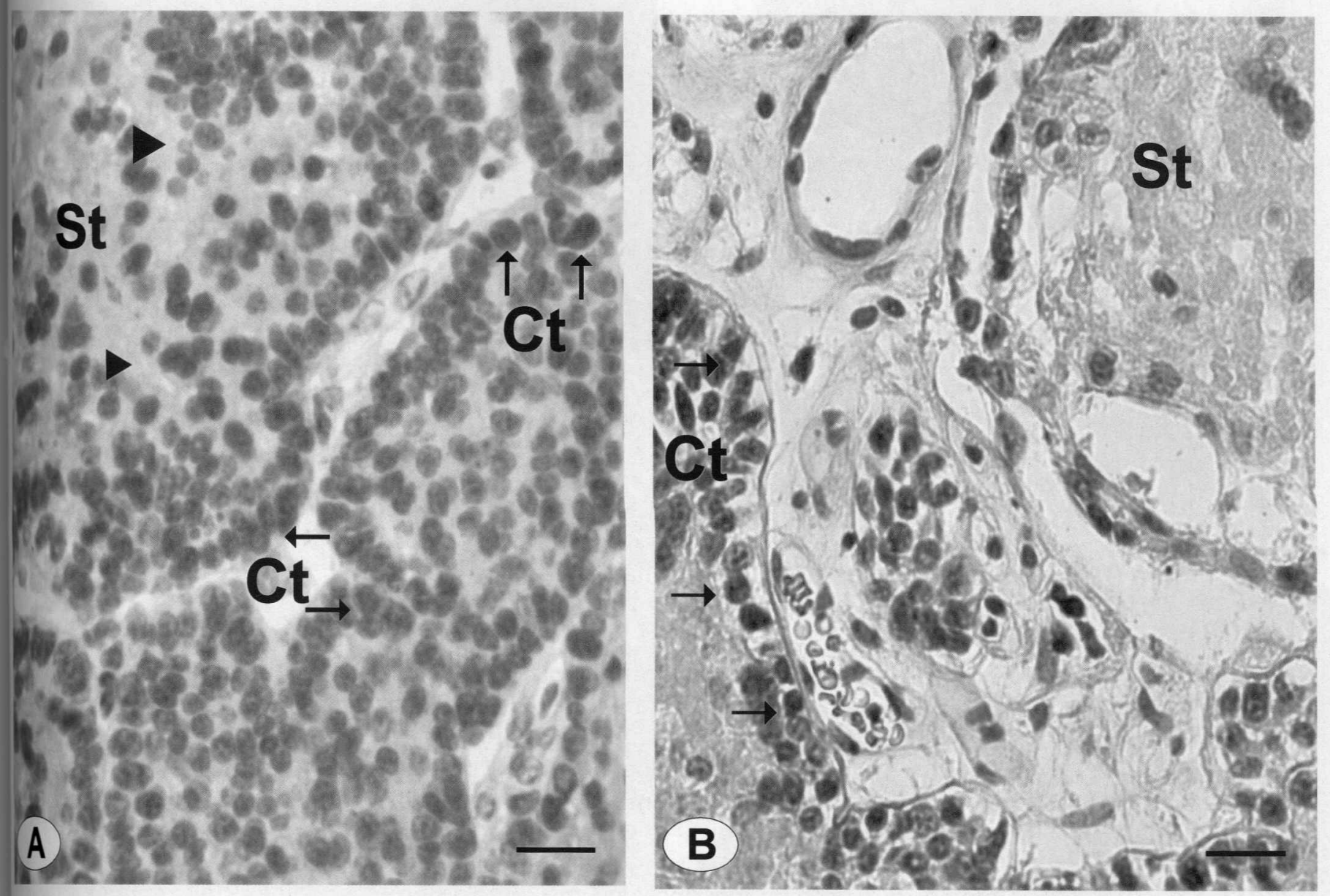
Figura 9 - Eletromicrografias da subplacenta da paca

A) Observar o aspecto do tecido conjuntivo mesenquimal (M) encontrado no eixo de uma lamela e as camadas de células citotrofoblásticas (Ct) perfiladas em arranjo epitelial. Observar os espaços intersticiais formados entre os prolongamentos citoplasmáticos das células trofoblásticas que aparentemente não apresentam qualquer conteúdo. $1 \mathrm{~cm}=3 \mu \mathrm{m}$

B) Detalhe do eixo mesenquimal de uma lamela com o endotélio de um vaso sanguíneo fetal $(\mathrm{V})$. Observar a lamina basal contínua e bem definida $(\mathrm{Lm})$ onde se apóia o citotrofoblasto (Ct) que estão unidas entre si através de junções celulares. $1 \mathrm{~cm}=2 \mu \mathrm{m}$

C) As células do citotrofoblasto (Ct) apresentam diferenças no conteúdo citoplasmático, porém não apresenta predomínio de organelas, exceto pela profusão de ribossomos livres. Os citotrofoblastos unem-se aos sinciciotrofoblastos (St) através de junções celulares (seta). $1 \mathrm{~cm}=1,7 \mu \mathrm{m}$

D) Notar os espaços dilatados formados entre as células do citotrofoblasto (Ct) através de seus prolongamentos citoplasmáticos. O sincíciotrofoblasto (St) pode ser facilmente distinguido do citotrofoblasto pela presença de grande quantidade de microvilos na sua superfície e faz união com o citotrofoblasto através de desmossomos (seta). $1 \mathrm{~cm}=2 \mu \mathrm{m}$ 


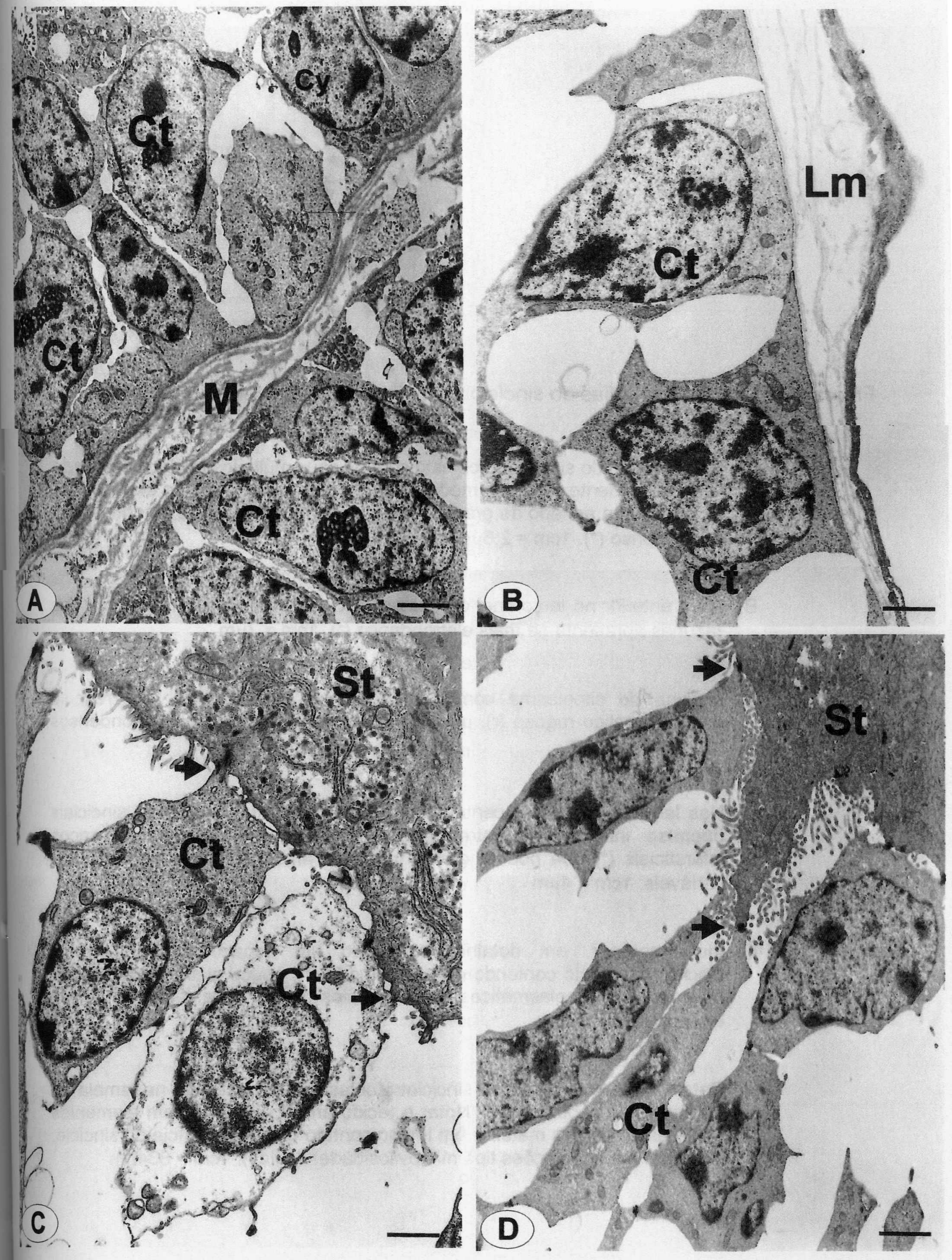


Figura 10 - Eletromicrografias do sincíciotrofoblasto da subplacenta da paca

A) Aspecto geral do sinciciotrofoblasto com os seus múltiplos núcleos contendo nucléolo evidente, no terço médio da gestação. Notar áreas de extração (\#) do citoplasma ao lado de grandes lacunas contendo material amorfo pouco eletrondenso $\left(^{*}\right) .1 \mathrm{~cm}=2,6 \mu \mathrm{m}$

B) Idem anterior no terço final de gestação. O material amorfo no interior das lacunas apresenta-se mais eletrondenso $\left(^{*}\right) .1 \mathrm{~cm}=7 \mu \mathrm{m}$

C) Detalhe do citoplasma com a presença de mitocôndrias $(m)$, retículo endoplasmático rugoso $(\mathrm{r})$, núcleo $(\mathrm{N})$ e pequenos grânulos eletrondensos (g). $1 \mathrm{~cm}=544 \mathrm{~nm}$

D) Nas lamelas presentes centralmente na subplacenta, as células sinciciais unem-se intimamente entre si, podendo delimitar pequenos espaços intersticiais $\left({ }^{*}\right)$ que podem conter materiais amorfos de eletrondensidade variáveis. $1 \mathrm{~cm}=4 \mu \mathrm{m}$

E) Idem anterior, em detalhe mostrando um espaço delimitado pelo sinciciotrofoblasto contendo material amorfo $\left({ }^{*}\right)$, pouco eletrondenso. Notar as projeções citoplasmáticas tipo microvilos (setas) para o interior destes espaços. $1 \mathrm{~cm}=2 \mu \mathrm{m}$

F) Detalhe de uma região do sinciciotrofoblasto (St) localizado na lamela do perímetro da subplacenta. Notar o tecido amorfo $\left(^{\star}\right)$ junto com elementos fibrilares de origem materna em íntimo contato com a superfície do sincício, que apresenta projeções tipo microvilosidades (setas). $1 \mathrm{~cm}=834 \mathrm{~nm}$ 


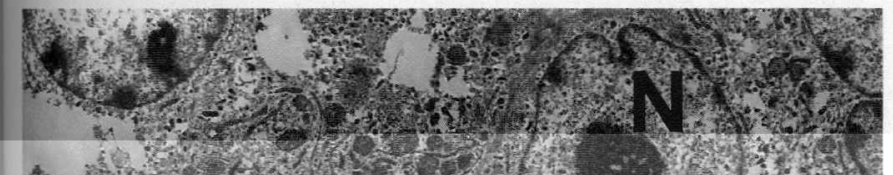

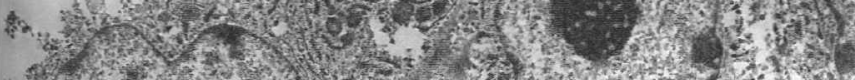
I.

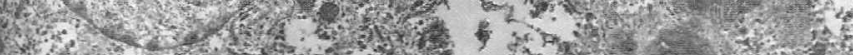

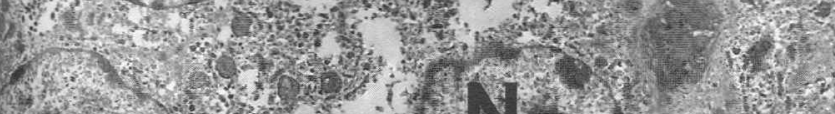

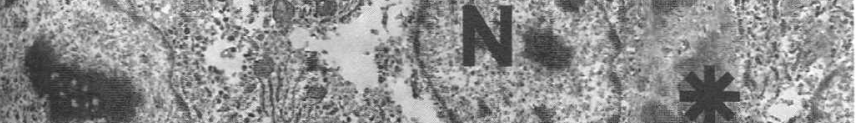

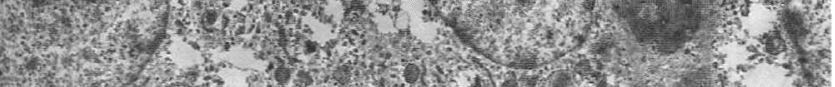
(A) \# 650 by

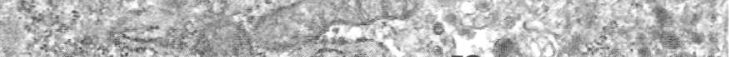

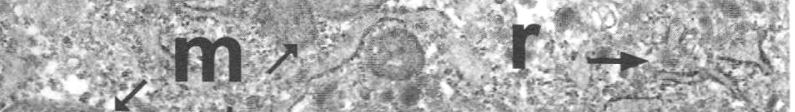

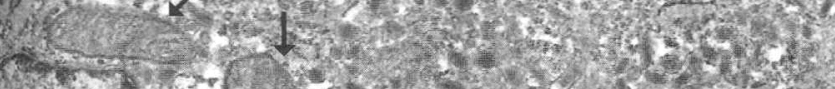

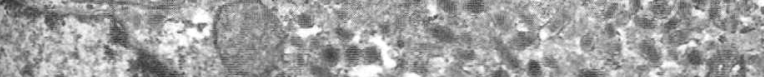

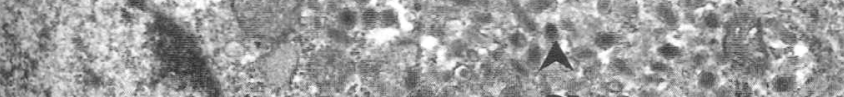

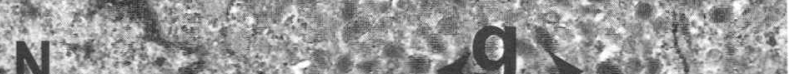
NDt A.t.

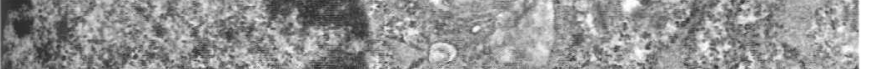

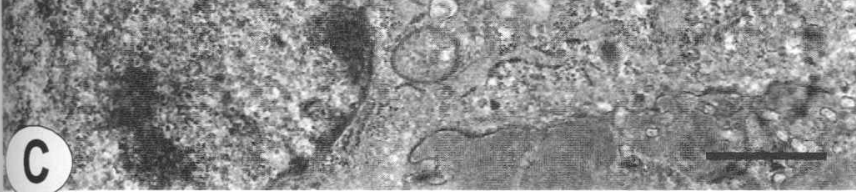
(195)

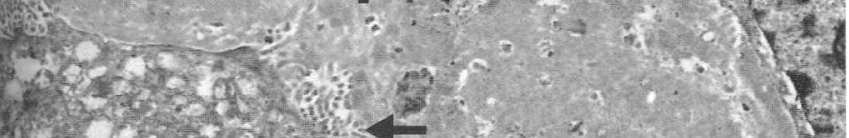

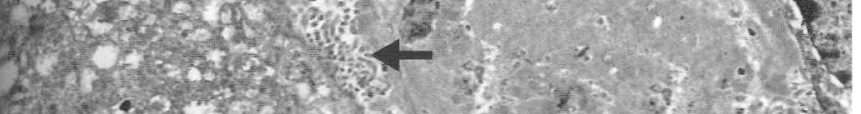

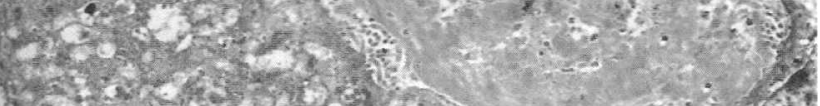
2.0.

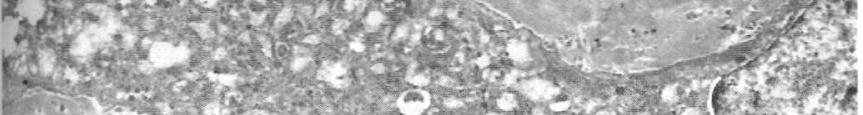
(E) 3 (3)

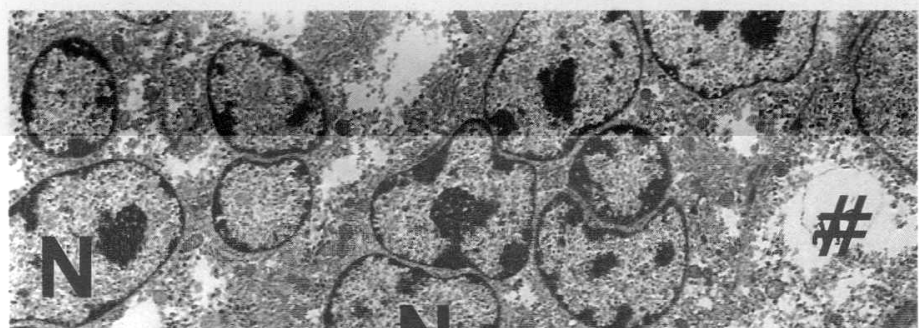
(2)

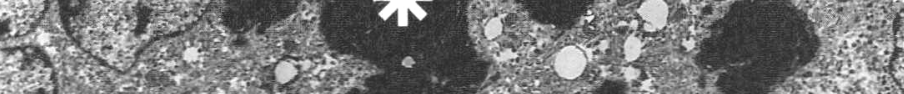
B.

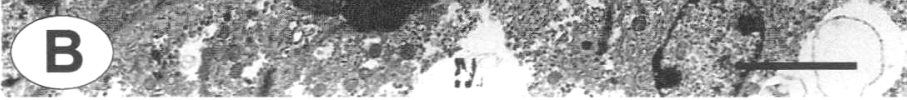
12.

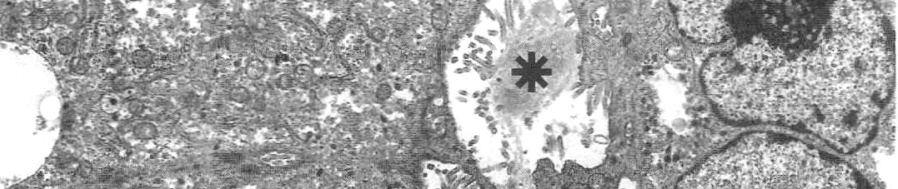
(IV) $7,13.62,2+260$

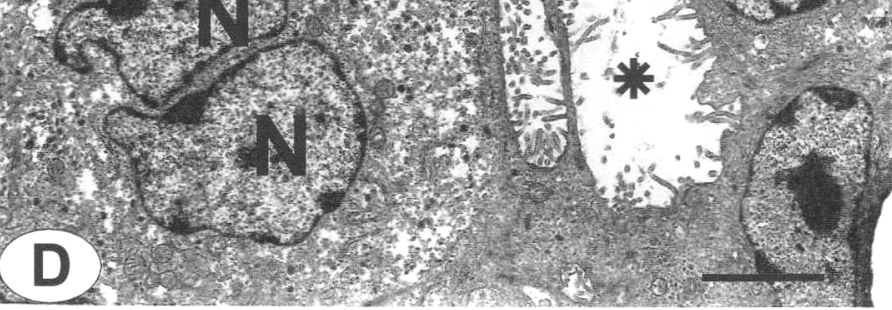

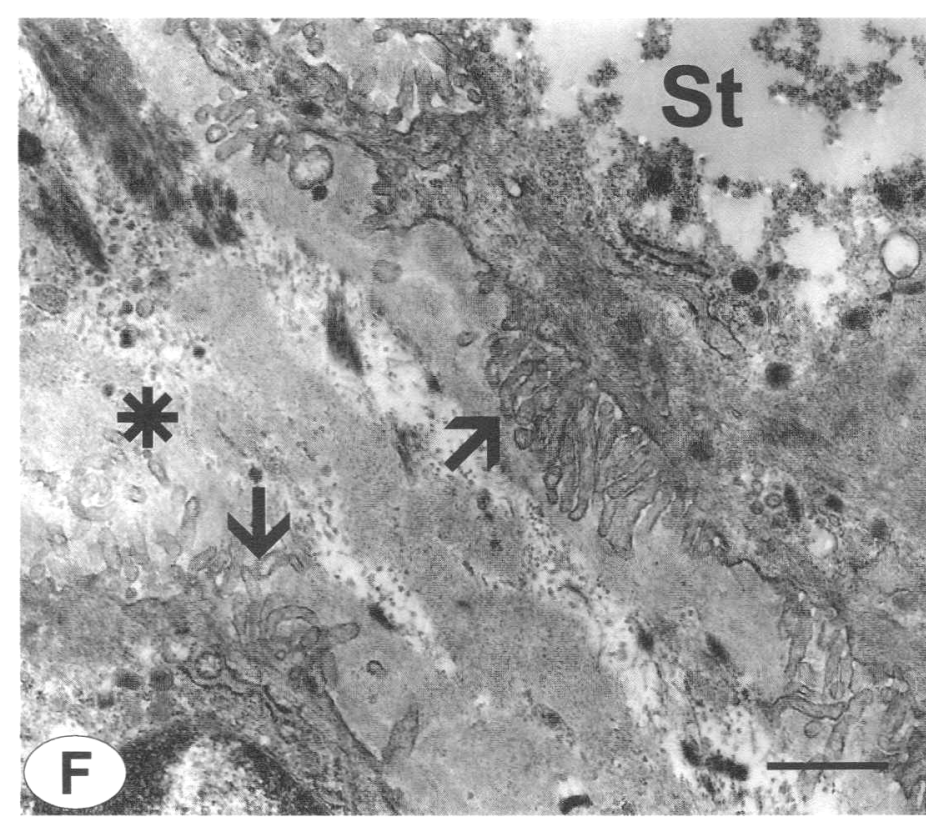


Figura 11 - Eletromicrografias das células trofoblásticas gigantes

A) Células trofoblásticas gigantes (G) em íntima associação com 0 sinciciotrofoblasto $(\mathrm{St})$ presentes em lamelas localizados no perímetro da subplacenta em contato com o tecido materno. $1 \mathrm{~cm}=2,5 \mu \mathrm{m}$

B) Agregado de células trofoblásticas gigantes (G) multinucleadas em arranjo epitelióide. Notar o delineamento do perímetro celular decorrente da deposição de filamentos junto à membrana plasmática (setas) e o citoplasma com extensas áreas de extração (\#), semelhantes àquelas encontradas nos sinciciotrofoblastos. $1 \mathrm{~cm}=7 \mu \mathrm{m}$

C) Detalhe do citoplasma do trofoblasto gigante apresentando áreas de extração citoplasmática (\#) e grânulos eletrondendos (g) semelhantes àquelas encontradas no sinciciotrofoblasto. Notar 0 alinhamento de filamentos $(\leftrightarrows)$ na interface com células gigante contígua e nas bordas livres que apresenta microvilos semelhantes àquelas encontradas no sinciciotrofoblasto (cabeça de setas). $1 \mathrm{~cm}=1,4 \mu \mathrm{m}$

D) Detalhe da região de alinhamento dos feixes de filamentos $(\downarrow \uparrow)$. Notar a ausência da membrana plasmática, o que conota a ocorrência de fusão celular entre as células trofoblásticas gigantes. $1 \mathrm{~cm}=223 \mathrm{~nm}$ 


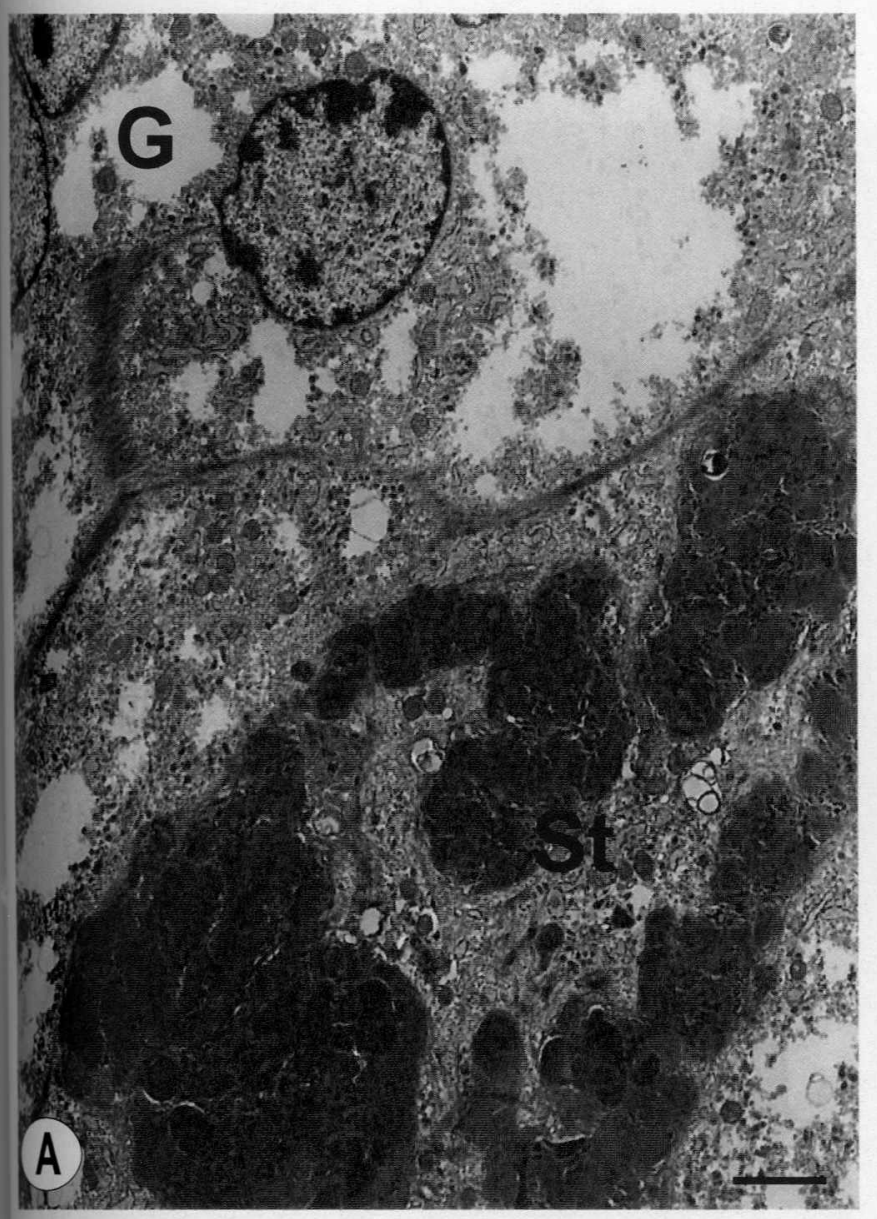

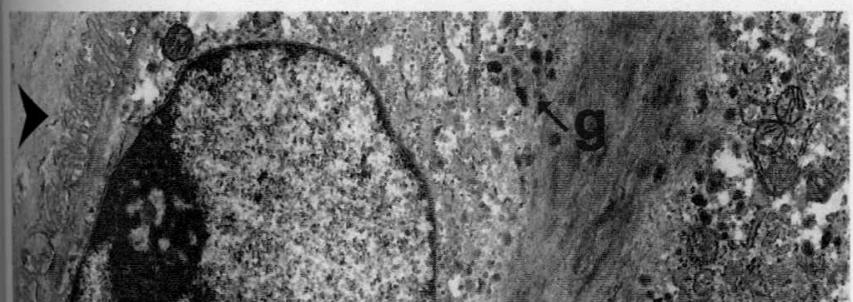
H Mrom

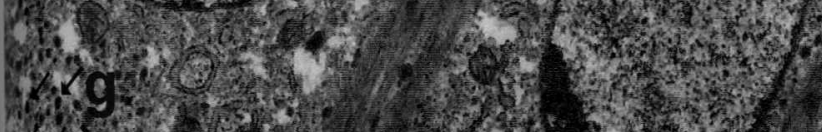
Math P.n

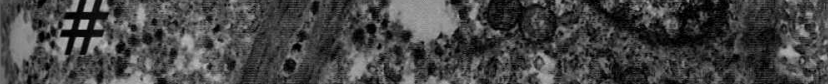

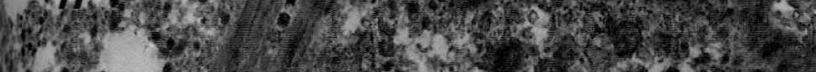

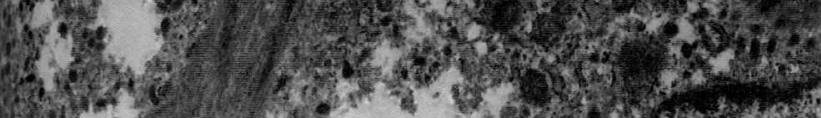

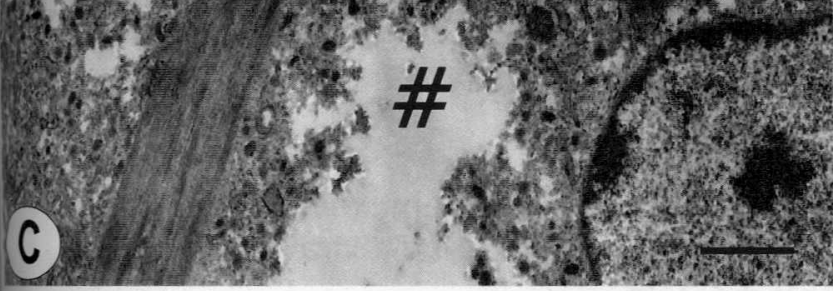
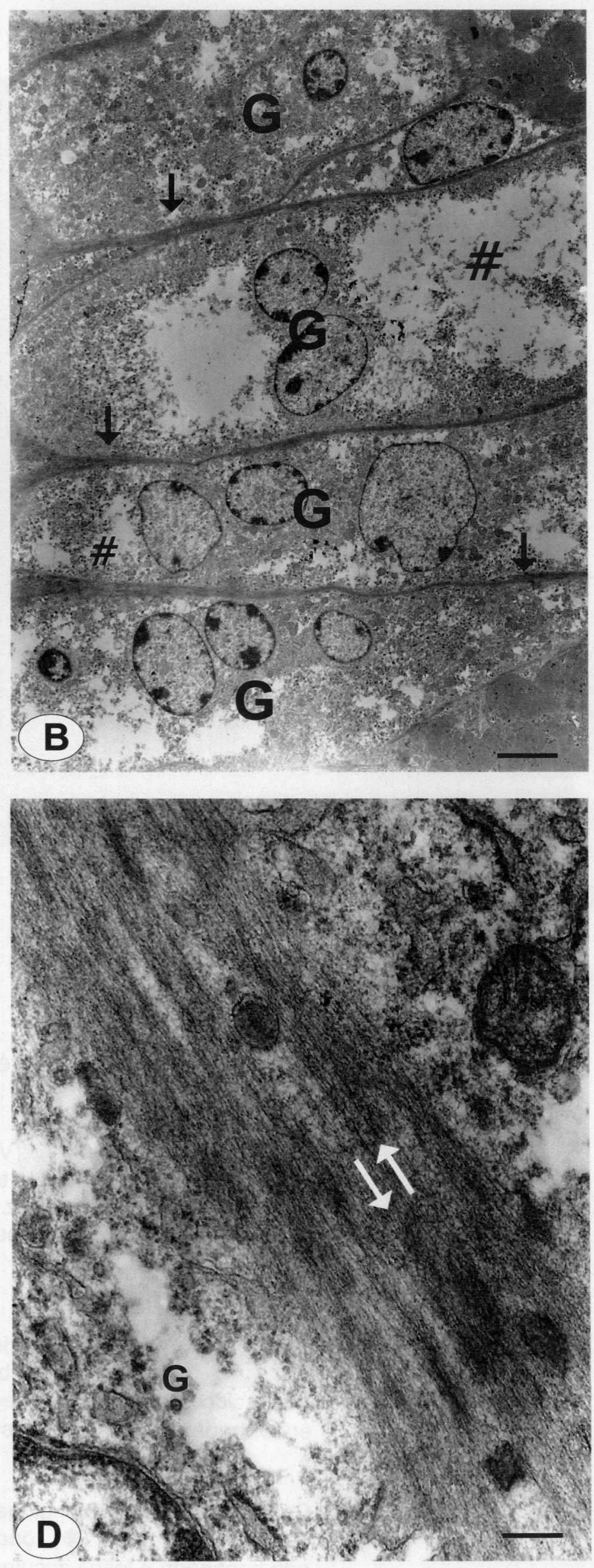
Figura 12 - Eletromicrografias do endométrio localizado próximo à subplacenta

A) Ramo vascular materno (V) de pequeno calibre, onde se observa a presença de uma célula trofoblástica sincicial única (St) formando o revestimento contínuo da luz do vaso. Notar as massas amorfas de aspecto nodular (*) que são comumente encontrados ao redor dos vasos maternos alterados. $1 \mathrm{~cm}=2,7 \mu \mathrm{m}$

B) Detalhe de uma parede de vaso sanguíneo materno (V) onde a luz destituída de endotélio é substituída por células sinciciais (St). Entremeado ao tecido amorfo (*) degenerado da parede do vaso podem ser encontradas células trofoblásticas gigantes $(\mathrm{G}) .1 \mathrm{~cm}=11 \mu \mathrm{m}$

C) Células trofoblásticas gingantes $(G)$ encontrados em meio ao tecido endometrial amorfo (*), onde o sangue aparenta estar extravasado (Sg), não confinado a leito vascular. $1 \mathrm{~cm}=1,7 \mu \mathrm{m}$ 

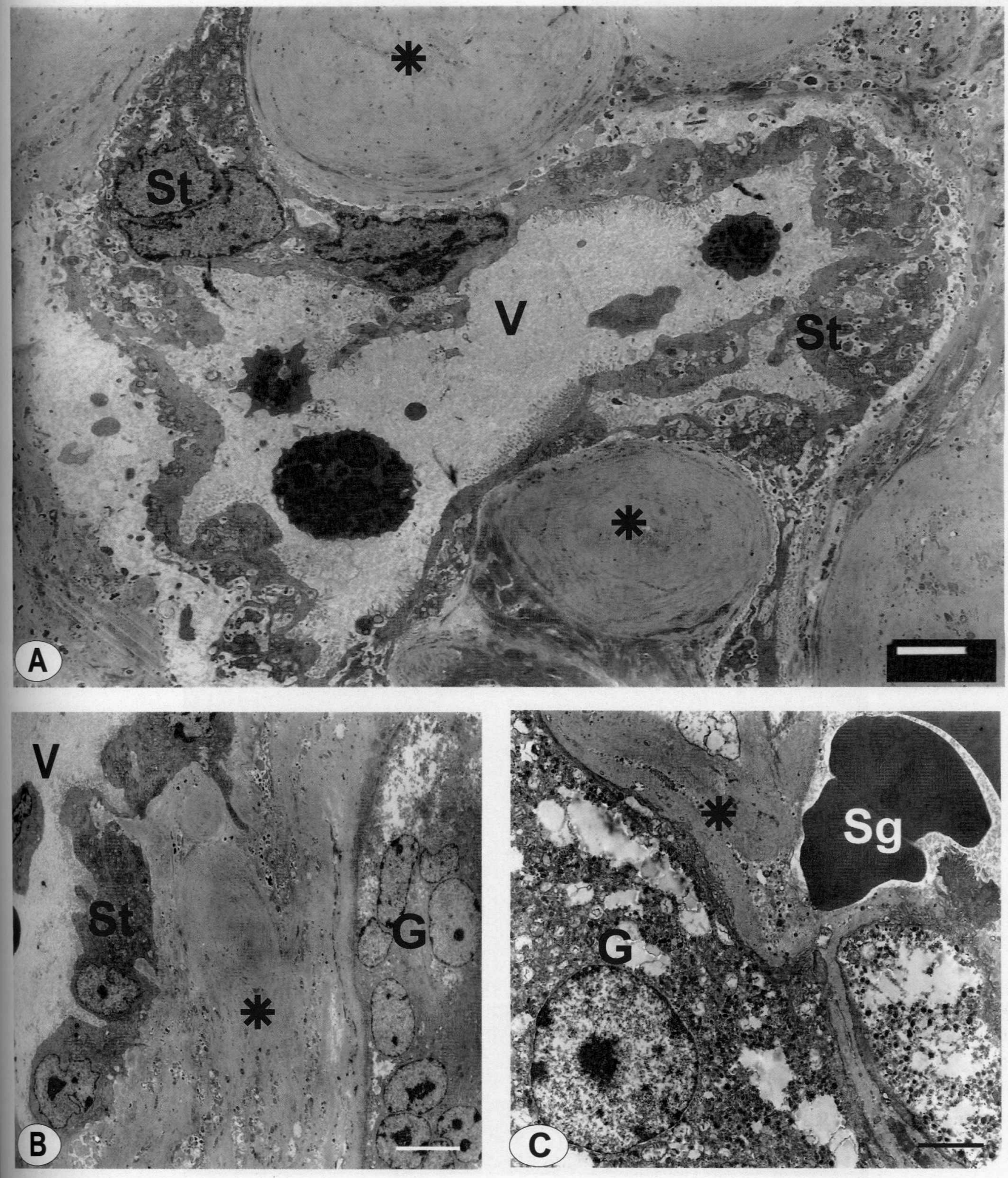
Figura 13 - Vascularização da subplacenta

A) Molde da vascularização da placenta obtida através da perfusão de látex pelo ramo arterial fetal do cordão umbilical. A porção inferior maior, corresponde à estrutura da rede vascular dos lóbulos da placenta principal $(P)$. A subplacenta $(S)$ constitui-se como uma protuberância na porção superior do molde, conectada à placenta principal através de um ramo vascular arterial mais calibroso (Vc) que se insere centralmente a subplacenta. Paralelamente a este ramo maior, vários vasos de menor calibre inseremse perpendicularmente entre a subplacenta e a placenta principal (Vp).

B) Corte sagital da placenta da paca no terço final de gestação, injetado com látex neoprene colorido: Vermelho (artéria fetal), Amarelo (veia fetal), Verde (veia materna) e Branco (artéria materna). Notar na placenta principal $(P)$ as irrigações através de vasos arteriais e venosos tanto fetais quanto maternas, enquanto que na subplacenta, a perfusão ocorre exclusivamente através de artéria fetal (vermelho). 

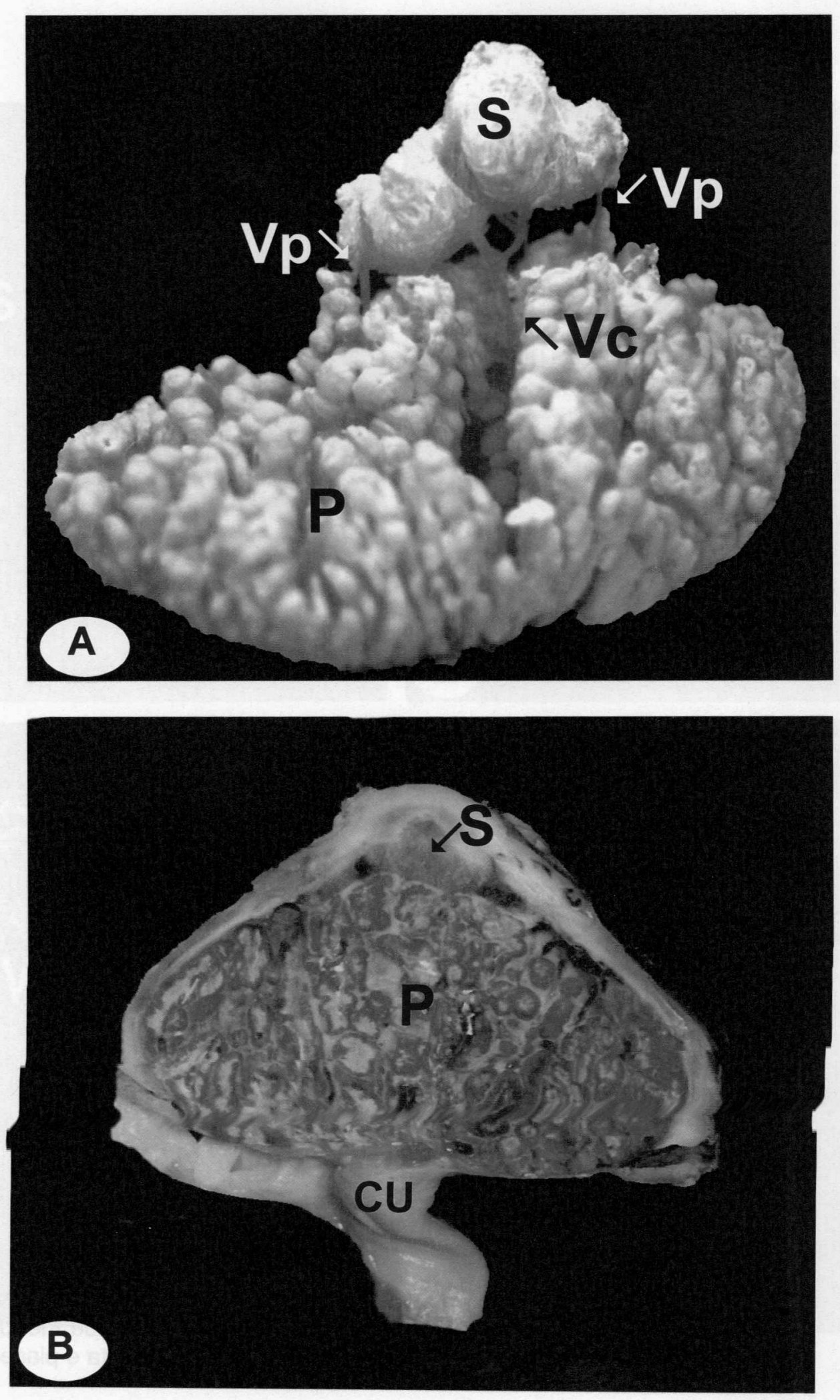
Figura 14 - Micrografia eletrônica de varredura de molde da vascularização da placenta

A) A rede vascular da subplacenta com o vaso central (Vc) oriundo da placenta principal inserindo-se na porção mediana da subplacenta.

B) Detalhe do anterior mostrando o vaso central (Vc) se ramificando ao se inserir na subplacenta. Notar dois ramos de vasos de menor calibre (Vp) que se inserem perpendicularmente entre a subplacenta e placenta principal.

C) Detalhe da rede vascular da subplacenta, que apresenta trajeto tortuoso, na sua grande maioria constituída de vasos de pequeno calibre.

D) Idem anterior, mostrando os detalhes da superfície luminal dos vasos. Notar os estrangulamentos (setas) e as ramificações. 

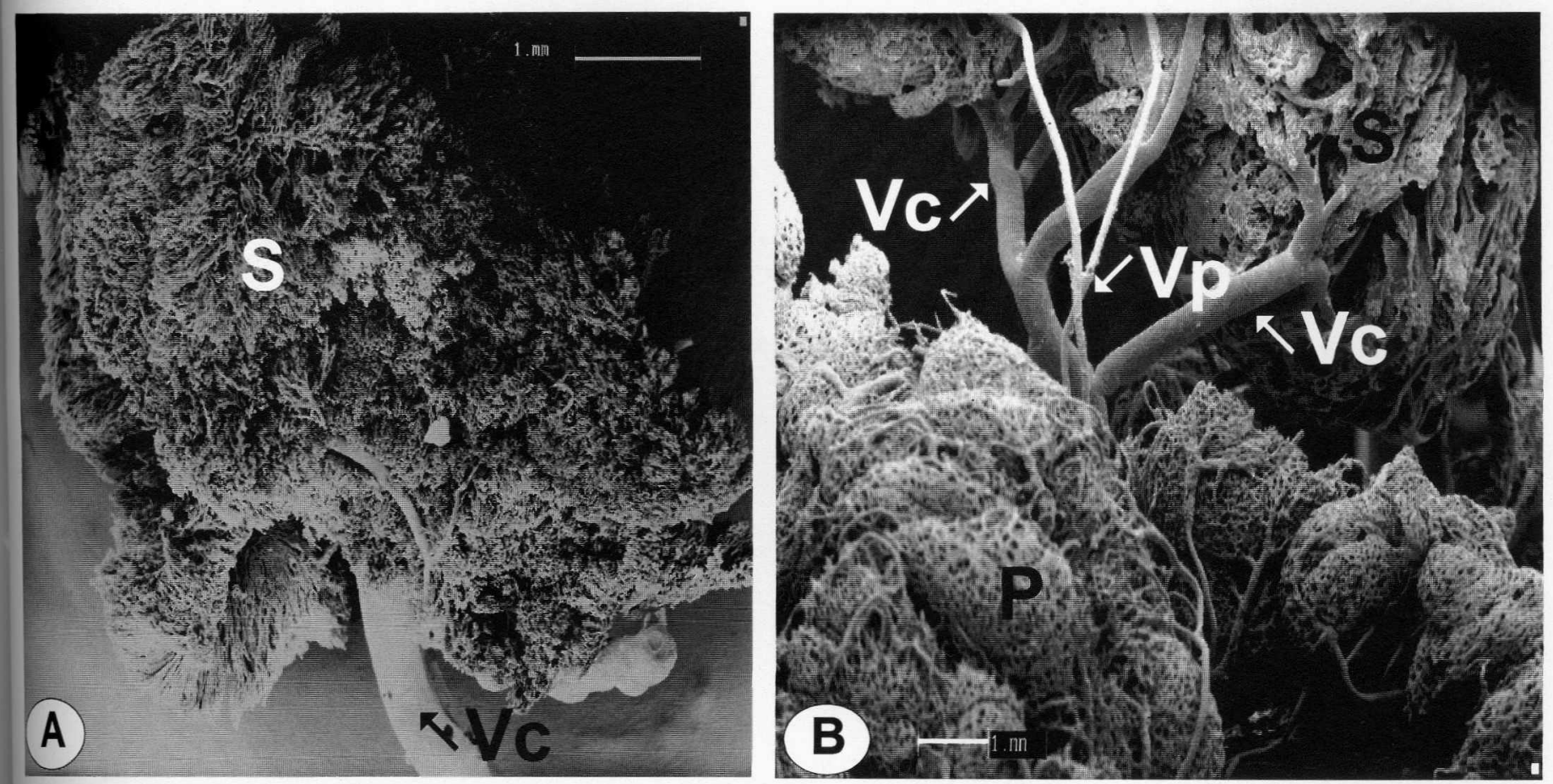

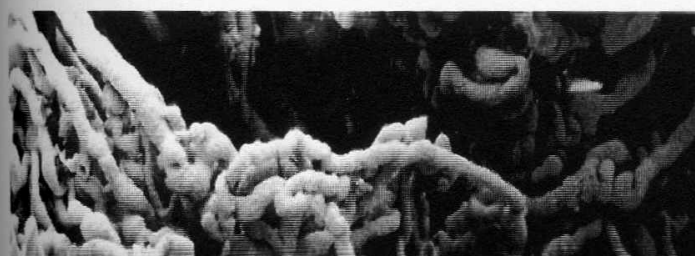

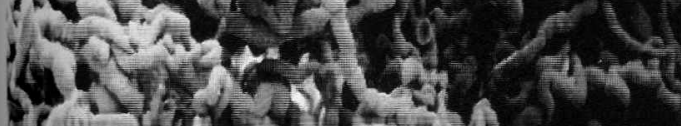
Ex 15 . Ext Sxats

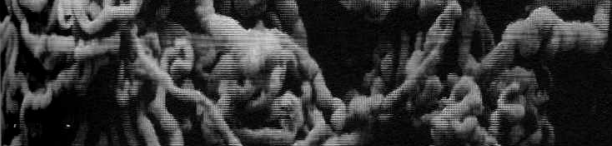
6 and
Winte. axy से⿺𠃊

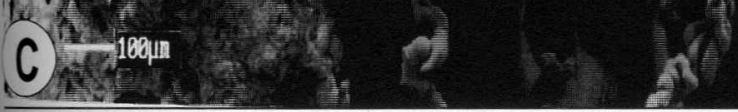

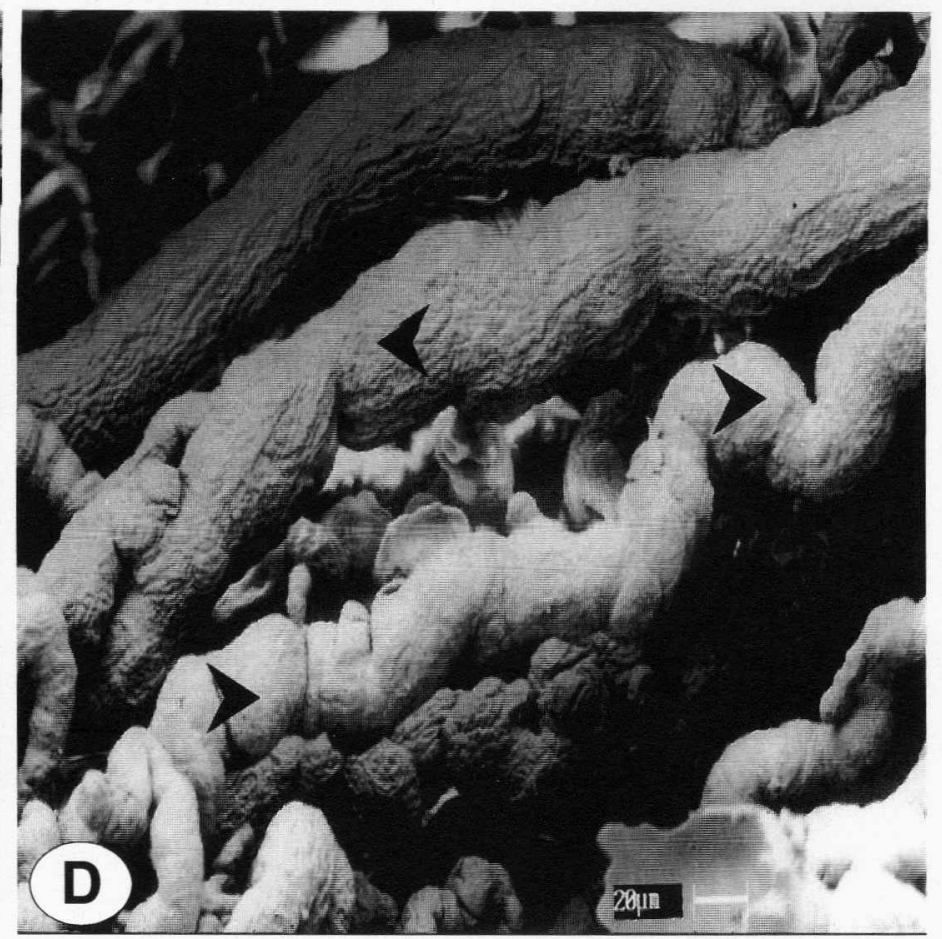


Discussão 


\section{DISCUSSÃO}

A subplacenta é uma estrutura da placenta dos roedores da sub-ordem histricomorfos e, na paca, foi originalmente descrita por Bonatelli et al. $(2001,2005)$. A placenta da paca (Agouti paca) tem um formato cuneiforme e integra-se à parede uterina, formando uma protuberância discóide na face voltada para o feto, e o ápice inserido na parede uterina. A subplacenta localiza-se nesse ápice em íntimo contato com o endométrio e apoiada na placenta principal. Esse aspecto é observado tanto no terço final quanto no terço médio da gestação. Essa localização da subplacenta no perímetro da placenta em íntimo contato com o endométrio é semelhante à descrita para cobaia (DAVIES; DEMPSEY; AMOROSO 1961b; UHLENDORF; KAUFMANN, 1979), porém difere da localização descrita para nutria (HILLEMANN; GAYNOR, 1961), que tem a subplacenta espalhada junto aos lóbulos da placenta principal corioalantoidiana.

A histoarquitetura da subplacenta da paca em formações de lamelas, cujo eixo apresenta o tecido conjuntivo mesenquimal, contíguo ao tecido mesenquimal encontrado na base da subplacenta, que, por sua vez, é contíguo ao tecido mesenquimal que preenche os lóbulos da placenta principal. Essa comunicação através do tecido conjuntivo mesenquimal atesta a integração da subplacenta à placenta principal, embora, a partir do terço médio da gestação, a localização e organização da subplacenta da paca aparentem uma estrutura independente. De fato, pela observação cuidadosa do tecido intersticial mesenquimal entre a subplacenta e a placenta principal, 
percebe-se que esse tecido não entra em comunicação com o tecido de origem materna, sendo constantemente interposto pelas células trofoblásticas.

Nas lamelas da subplacenta, sobre o tecido mesenquimal, apóiam-se camadas de citotrofoblasto e de sinciciotrofoblasto à semelhança das descrições encontradas para a subplacenta de outros histricomorfos (DAVIES; DEMPSEY; AMOROSO 1961b; HILLEMANN; GAYNOR; 1961; ODUOR-OKELO; GOMBE, 1982; UHLENDORF; KAUFMANN, 1979). Na subplacenta da paca, no terço médio de gestação, verifica-se uma estratificação bem definida de citotrofoblasto e sobre esta a de sincíciotrofoblasto que, em alguns pontos, ainda apresenta um íntimo contato com tecidos de origem materna em degeneração. As células sinciciotrofoblásticas caracterizam-se pela presença de inúmeros núcleos em meio ao citoplasma da célula, cujo limite torna-se impreciso à microscopia de luz. Essa localização e características morfológicas não diferem daquelas descritas para o sincíciotrofoblasto encontrado nas vilosidades coriônicas da placenta de humanos ou em lamelas da subplacenta de outros roedores (KAUFMANN, 2003; UHLENDORF; KAUFMANN, 1979).

No terço final da gestação, as áreas delimitadas pelos sinciciotrofoblastos das lamelas da subplacenta apresentam um material amorfo notadamente acelular e PAS positiva-amilase resistente. Esse material PAS positivo, encontrado junto ao sinciciotrofoblasto, deve ser resultante, em grande parte, do resíduo da degeneração do tecido endometrial confinado entre as lamelas da subplacenta.

A presença desse material de aspecto e consistência semelhantes também na interface da subplacenta com o tecido endometrial sugere que a expansão e o crescimento da placenta envolvem o progressivo avanço da subplacenta para o interior da parede uterina com o comprometimento do tecido endometrial. 
$\mathrm{Na}$ análise ultra-estrutural, as células trofoblásticas que constituem as lamelas apresentam domínios ocupados por células de características distintas. A camada de células que se apóiam na lâmina basal constitui-se tipicamente de células de arranjo epitelial com junções celulares do tipo desmossomas e adesivas, unindo prolongamentos de células contíguas dispostas em uma ou mais camadas. Essas células formam espaços intercelulares irregulares cujo interior não apresenta material preservado pelos métodos de fixação adotados. Seu conteúdo citoplasmático é semelhante aos descritos para citotrofoblasto das lamelas de subplacenta de outros roedores (KING; TIBBITTS, 1976), sendo evidente que, exceto pelos ribossomas livres, não há predomínio de qualquer conjunto de organelas, ou especializações nas superfícies livres da membrana plasmática que denote uma atividade funcional determinante, ou seja, a ultra-estrutura sugere o de uma célula pouco diferenciada.

As células citotrofoblásticas em geral têm sido apontadas células indiferenciadas da placenta, com alto poder proliferativo e fonte de outras células trofoblásticas em placentas de diferentes animais, inclusive de humanos (BERNISCHK; KAUFMANN, 2000; KAUFMANN, 2003). Perrota (1959) sugere que a subplacenta seria uma região "germinal" do trofoblasto e do mesoderma alantóico, na qual novos lóbulos do labirinto diferenciavam-se e eram adicionados à placenta durante seu crescimento. Tibbitts e Hillemann (1959) mencionam que a subplacenta da chinchila, assim como Davies, Dempsey e Amoroso (1961b), a da cobaia, sejam formadas no início do desenvolvimento da placenta corioalantoidiana. Há, portanto, relatos inconclusivos quanto à origem da subplacenta, sendo o mais provável, a ocorrência de variações filogenéticas e evolutivas entre as espécies, o que ainda necessita ser estabelecido. 
Embora não tenham sido coletadas e analisadas placentas no início de sua formação, os resultados do presente trabalho corroboram a possibilidade de o citotrofoblasto contribuir para o crescimento e desenvolvimento tanto da subplacenta quanto da placenta principal da paca. Isto é, a intensa marcação positiva pelo PCNA, que identifica núcleo de células em proliferação, encontrada no citotrofoblastos das lamelas da subplacenta no terço médio da gestação, sugere uma demanda de células trofoblásticas na subplacenta e placenta em desenvolvimento. Porém essa intensa proliferação do citotrofoblasto, não resulta no aumento preponderante do próprio citotrofoblasto como se observa com a progressão da gestação. Ao contrário, no final da gestação, nota-se uma redução nas camadas de citotrofoblasto presentes nas lamelas, o que faz presumir o direcionamento dessas células como fonte para a origem e diferenciação de outras células trofoblásticas encontradas na placenta de histricomorfos, tais como as células gigantes, sinciciotrofoblastos e mesmo as células labirintotrofoblásticas. De acordo com Hupperts et al. (1999), há uma demanda de proliferação do citotrofoblasto para formação do sinciciotrofoblasto até o terço médio da gestação em humanos, cessando, porém, no terço final. A marcação positiva em núcleos do citotrofoblasto presente na subplacenta da paca aponta, embora em escala menor, a manutenção dessa capacidade proliferativa do citotrofoblasto até o final da gestação, diferindo da espécie humana, apesar de se poder pressupor sua participação na demanda de prover populações de células trofoblásticas da placenta, em particular os sinciciotrofoblastos.

As análises pelo microscópio eletrônico revelam os sinciciotrofoblastos multinucleados, unidos entre si e aos citotrofoblastos por meio de junções celulares do tipo aderentes, delimitando espaços intercelulares de dimensões variadas. A 
sugerindo a presença de cadeias longas de polissacarídeos neutros tipo glicogênio, o que pode ser também aferido nas observações no microscópio eletrônico. Por outro lado, a reatividade mantida após a amilase comprova a presença de outras formas de glicoconjugados não susceptíveis a essa enzima.

As enzimas lisossomais, em sua grande maioria, são de natureza glicoprotéica com ampla gama de atuação (GROH; MAYERSBACH, 1981) e podem ser reveladas pela reação de PAS nas células que apresentam grande quantidade dessas organelas, como no caso das células trofoblásticas gigantes de camundongos (AMARANTEPAFFARO et al., 2004).

Roberts e Perry (1974) especularam sobre a presença de material PASpositivo na subplacenta de vários caviomorfos com a possibilidade de a subplacenta estar envolvida no transporte de nutrientes, especialmente de substâncias de pesos moleculares elevados, como os polissacarídeos, da decídua para o feto. No entanto a subplacenta da paca não apresenta organização ou estruturação voltada para transporte ou tráfico de substâncias de forma eficiente.

Dentre as possíveis funções da subplacenta, sugere-se que essa estrutura possa conter células com potencial endócrino na gestação (DAVIES, DEMPSEY; AMOROSO,1961b; KING; TIBBITTS, 1976) e esse conteúdo amorfo retido entre as células sinciciais seja parte de seu produto de secreção, como, por exemplo, a produção de uma proteína ligante concentradora de progesterona (MESS, 2003). De fato, os grânulos citoplasmáticos das células sinciciais observados na ultra-estrutura poderiam ser vesículas que contêm produtos de síntese passíveis de secreção pelo mecanismo de exocitose. No entanto os aspectos ultra-estruturais dessas células não denotam qualquer polarização que determine uma possível secreção direcionada da célula. A interposição de duas ou mais camadas de citotrofoblasto 
entre o sincício e o leito vascular fetal presente no eixo das lamelas não condiz com a organização e eficiência esperada de tecidos epiteliais, notadamente endócrinos, encontrados em outros órgãos. Na interface oposta do sincíciotrofoblasto, isto é, a que entra em contato íntimo com o tecido materno, não são encontrados vasos de origem materna íntegros ou próximos deduzindo-se, portanto, serem pouco eficientes para essa forma de interação ou função. Além disso, o conteúdo amorfo e aparentemente homogêneo observado em meio às lamelas da subplacenta que apresenta reação PAS positiva- amilase resistente, quando observado no microscópio eletrônico, condiz muito mais com um material resultante da degeneração parcial dos componentes celulares e da matriz extra-celular do tecido endometrial, retido em meio às células sincíciotrofoblásticas da subplacenta.

Nesse material amorfo em degradação, foi constatada a presença de carboidratos ácidos (sulfatados e carboxilados), por meio da coloração de Alcian Blue $\mathrm{pH} 2,5$, os quais devem ser resíduos remanescentes dos componentes da matriz extracelular do estroma endometrial.

A vascularização da subplacenta merece atenção especial, considerando as funções que têm sido atribuídas a essa estrutura e às células que a constituem. A perfusão vascular de látex neoprene colorido demonstra, de forma inequívoca, os trajetos dos vasos fetais e maternos, pelos quais é notório que a subplacenta não recebe drenagem direta do sangue materno. Esses dados corroboram os relatos de Hillemann e Gaynor (1961) para a nutria (Myocastor coypus), que descrevem a maioria dos vasos maternos desviando-se da subplacenta em direção à placenta corioalantoidiana. Junto com a perfusão de neoprene colorido, o molde microvascular de corrosão demonstra que o interior da subplacenta é irrigado exclusivamente pelo 
sangue arterial oriundo de um ramo arterial principal ascendente que percorre o centro da placenta principal e insere-se na base da subplacenta. Este se ramifica e forma vasos de pequeno calibre que formam uma delicada rede, o que coincide com as observações realizadas em preparados histológicos e em microscopia eletrônica. Nestes, observam-se ramos venosos de pequeno calibre e capilares em meio ao tecido mesenquimal que preenche as lamelas, apesar de não serem encontrados ramos arteriais no interior das lamelas. A imunocitoquímica realizada com anti-vimentina e anti-citoqueratina comprova ainda que os vasos sangüíneos encontrados na subplacenta apresentam revestimento endotelial íntegro, sem a participação de células trofoblásticas em seu revestimento, comprova ser a vascularização intra-subplacentária realizada exclusivamente por vasos fetais. Esses dados vêm ao encontro dos dados sobre vascularização da subplacenta descritos em outros animais histricomorfos (MIGLINO et al., 2004; UHLENDORF; KAUFMANN, 1979; WOLFER; KAUFMANN, 1980).

No entanto o fato de a subplacenta não receber sangue arterial materno, ou apresentar qualquer organização que lembre uma possível drenagem do tipo contracorrente entre o sangue materno e fetal, como aquela encontrada na placenta principal (MIGLINO et al., 2004), sugere que a nutrição e oxigenação das células da subplacenta ocorrem exclusivamente através do sangue venoso oriundo do feto trazido pela artéria do cordão umbilical. É inegável a ocorrência da capilarização no interior da subplacenta percorrendo junto ao eixo de tecido conjuntivo mesenquimal e a confluência desses capilares para vasos venosos trazendo metabólitos e catabólitos, produtos da interação com as diversas células do interior da subplacenta que devem ser depurados e oxigenados antes de serem devolvidos ao feto, através do ramo venoso do cordão umbilical. De acordo com Starck (1957) e Kaufmann (2004), a vascularização da 
subplacenta na cobaia ocorre através de uma artéria central que se capilariza na subplacenta e retorna em ramos de vasos venosos que confluem com os ramos venosos oriundos da placenta principal e direcionam-se diretamente ao cordão umbilical.

Nossa interpretação da vascularização da subplacenta/placenta diverge quanto ao destino do sangue venoso oriundo da subplacenta, considerando-se que esse aporte de sangue venoso que circula pela subplacenta deva ser adequadamente oxigenado antes de retornar à circulação fetal. A existência de ramos vasculares menores que percorrem perpendicularmente a região da interface subplacenta/placenta (zona transicional) ao longo da base da subplacenta, sugere a possibilidade de esses ramos serem vasos venosos que drenam os capilares da subplacenta e que são direcionados para os lóbulos da placenta principal. Desta forma, o sangue oriundo da subplacenta pode realizar as trocas metabólicas normais por meio da circulação de contra-corrente no labirinto da placenta principal antes de retornar à circulação fetal. Tal interpretação é condizente com uma circulação portal própria da placenta de histricomorfos que desenvolvem uma estrutura subplacentária anatômica e funcionalmente isolada da placenta principal, como no caso da paca.

Esta circulação portal da subplacenta torna-se particularmente atraente do ponto de vista funcional, favorecendo a hipótese do controle preponderantemente fetal dessa estrutura. Em se considerando as possíveis funções sugeridas para a subplacenta, a primeira faz alusão a essa estrutura como sendo a fonte de células trofoblásticas para o desenvolvimento e crescimento da placenta. Embora haja controvérsia sobre os mecanismos de controle sobre as células trofoblásticas, estas notadamente proliferam e se diferenciam nas várias subpopulações de trofoblastos, de acordo com a demanda nutricional necessária para o crescimento embrionário/fetal 
(BILLINGTON, 1971). Para tanto, as informações primárias oriundas do embrião/feto devem sinalizar células competentes que comandem a sinalização secundária na própria placenta e/ou na interface materno-fetal para a resposta adequada. O retorno do sangue que circula pela subplacenta para a placenta principal, onde ocorre de fato as trocas metabólicas com o sangue materno, seria estratégico para uma sinalização imediata junto ao organismo materno.

Exceto pela zona transicional que une a subplacenta à placenta principal, que é constituída de tecido mesenquimal de origem fetal, os perímetros lateral e apical da subplacenta entram em íntimo contato com o tecido materno. Nessa interface, a celularidade das lamelas também apresenta, além do sinciciotrofoblasto, as células trofoblásticas gigantes. Essas últimas normalmente formam agregados de tamanhos variados que, quando observados no microscópio eletrônico, apresentam espessamentos formados por feixes de filamentos intermediários junto à superfície de contato entre as células trofoblásticas. Esse arranjo é peculiar dessas células e aparentemente essa área de contato intercelular torna-se destituída de membrana plasmática com a ocorrência de fusão celular, sendo provavelmente este o mecanismo que resulta em células gigantes multinucleadas. O citoplasma dessas células apresenta diversas organelas, ressaltando a presença das pequenas vesículas eletrondensas, semelhantes àquelas encontradas no sinciciotrofoblasto. A superfície celular apresenta inúmeras projeções tipo microvilosidades, também semelhantes àquelas encontradas nos sinciciotrofoblastos. No entanto estas diferem das células sinciciais, pela presença desses feixes de filamentos intermediários que se alinham junto à membrana plasmática.

Grupos de células trofoblásticas gigantes podem ser encontrados distantes da subplacenta, em meio ao tecido materno degenerado, que freqüentemente apresenta 
áreas de extravasamento sangüíneo. Esse tecido materno, na sua maior extensão, é amorfo, sem que seja possível distinguir sua celularidade original, denotando avançado estado de desestruturação e degeneração dos elementos do tecido endometrial. Algumas áreas em que a ocorrência de grupos de células gigantes é maior apresentam constituintes PAS positivos amilase-resistentes, semelhantes àqueles encontrados no interior dos espaços interlamelares da subplacenta, o que denota o acometimento do tecido endometrial num processo de degeneração igual ao daquele encontrado junto à subplacenta. Na ultra-estrutura, conquanto seja possível a identificação das células trofoblásticas gigantes e do sincíciotrofoblasto, o interstício entre estes é formado por uma massa amorfa, de eletrodensidade variável, totalmente acelular, não sendo possível distinguir morfologicamente qualquer elemento fibrilar da matriz extra-celular. Apesar desse avançado estado de comprometimento do tecido endometrial, não se observa qualquer infiltração leucocitária digna de nota ou que lembre uma reação inflamatória.

Cumpre salientar o comprometimento dos vasos sangüíneos maternos em toda a extensão do endométrio, que faz a interface com a subplacenta na parede uterina. A parede desses vasos está invariavelmente desorganizada, tendo seu revestimento endotelial destituído e substituído pelo sinciciotrofoblasto. Nos vasos sangüíneos de maior calibre, sobretudo os arteriais, a túnica média apresenta infiltrações de células trofoblásticas gigantes e sinciciais. Essa invasão dos vasos sangüíneos pelo sinciciotrofoblasto foi amplamente descrita na cobaia (NANAEV et al. 1995,2000), na qual atinge vasos sangüíneos presentes no miométrio, perimétrio e até mesmo em áreas extra-uterinas. Em nossas observações, as células trofoblásticas da paca parecem ser menos invasivas do que as da cobaia, uma vez que há um nítido limite no comprometimento dos vasos e do próprio endométrio no 
útero da paca. Mesmo no terço final da gestação, os vasos invadidos pelos trofoblastos estão restritos àqueles encontrados no endométrio cujo estroma se encontra em degeneração. Já nos vasos arteriais e venosos presentes no endométrio decidualizado íntegro, as paredes encontram-se integralmente revestidas por células endoteliais e as demais túnicas apresentam-se íntegras.

Essa diferença no avanço invasivo das células trofoblásticas aponta para uma diversidade de comportamento mesmo entre os histricomorfos, e que merece estudos comparativos mais aprofundados no futuro.

A presença tanto de células trofoblásticas gigantes quanto de sinciciotrofoblastos no interstício do tecido endometrial e nas paredes dos vasos indica uma capacidade invasiva equivalente. A ocorrência da capacidade invasiva do sinciciotrofoblasto é amplamente conhecida, sendo o melhor exemplo a própria espécie humana (POLLHEIMER; KNOFLER, 2005). Nos animais de placentação hemocorial que não apresentam o sinciciotrofoblasto, como ratos e camundongos, o papel invasivo é desempenhado pelas células trofoblásticas gigantes (BEVILACQUA; ABRAHAMSOHN, 1988; WELSH; ENDERS, 1987). Desta forma, a paca apresenta a coexistência tanto do sinciciotrofoblasto quanto do trofoblasto gigante com função invasiva, sugerindo ser a placenta desse animal com sua subplacenta um elo na filogenia e evolução entre a placenta de roedores e a de primatas.

Apesar da coexistência simultânea do sinciciotrofoblasto e do trofoblasto gigante, observa-se uma preferência de localização do sincíciotrofoblasto junto aos vasos sangüíneos, notadamente junto à luz desses vasos, enquanto os agregados de células gigantes são comumente encontrados em meio ao interstício do endométrio comprometido ocupando as túnicas adventícias e médias dos vasos arteriais. Esses 
predomínios de localização sugerem vias de progressão invasiva distintas para as duas populações na consolidação da placentação hemocorial, tendo aparentemente o sinciciotrofoblasto adotado preferencialmente o leito vascular, enquanto o trofoblasto gigante insinua-se entre o estroma endometrial.

A ocupação estratégica da parede dos vasos arteriais maternos do endométrio pelas células trofoblásticas sugere que estas assumem o controle do fluxo sangüíneo destinado à irrigação do labirinto placentário, que, por sua vez, é imprescindível para a nutrição do feto em desenvolvimento. Reconhecidamente, as células trofoblásticas de humanos (KAKUI et al., 2003) e camundongos (GAGIOTI et al., 2000; HUNT et al., 1997) expressam a enzima óxido nítrico sintase induzível (iNOs) para a produção de óxido nítrico, o qual é um potente modulador do tônus vascular no ambiente uterino (PURCEL et al.,1997; OGANDO et al., 2003).

Esse controle da vascularização materna é um fenômeno ímpar no ambiente uterino, onde o estroma endometrial se encontra destituído totalmente de suas características originais, sendo ocupado por um tecido em avançado estado de degeneração, sem, contudo, acarretar ou induzir uma resposta materna para reconstituir a normalidade do endométrio. Tal nível de comprometimento do estroma endometrial na gestação não é reportado em outros modelos animais de placentação hemocorial, o que os torna um modelo de estudo interessante para a compreensão de mecanismos relacionados com o controle da interação materno-fetal durante a gestação. 
Conclusões 


\section{CONCLUSÕES}

1. A subplacenta da paca organiza-se como uma estrutura cuneiforme, cuja base mantém uma íntima associação com a placenta principal e insere-se no endométrio, perfazendo a interface maior com o tecido materno. Essa organização é identificada no terço médio da gestação e perdura até o final desta.

2. A histoarquitetura da subplacenta da paca apresenta formações lamelares, cujo eixo é composto por um mesênquima contendo vasos fetais, sobre o qual se apóiam as camadas de citotrofoblastos e dos sinciciotrofoblastos.

3. Nas lamelas do perímetro das faces laterais e apicais da placenta são encontradas ainda células trofoblásticas gigantes ao lado dos sinciciotrofoblastos, que entram em íntimo contato com o tecido materno.

4. Entre as células sinciciais das lamelas no interior da subplacenta, são encontrados materiais amorfos PAS positivos, que, observados no microscópio eletrônico, revelam ser resíduos de células degeneradas, provavelmente de origem materna. Esses resíduos devem decorrer do confinamento do tecido materno pelas células trofoblásticas durante o avanço destas para o interior do endométrio, no processo da placentação.

5. Tanto as células trofoblásticas sinciciais quanto as gigantes podem ser encontradas em áreas distantes da subplacenta e comprometem profundamente o endométrio, induzindo sua desestruturação. Os vasos sangüíneos presentes 
nesse endométrio comprometido apresentam-se destituídos de revestimento endotelial.

6. Os vasos sangüíneos maternos do endométrio comprometido apresentam seu revestimento endotelial substituído pelas células trofoblásticas sinciciais, e sua túnica média entremeada por células trofoblásticas gigantes, sugerindo que o leito vascular pode ser utilizado pelas células sinciciais para a progressão da invasão.

7. A presença de células trofoblásticas gigantes em meio ao tecido endometrial comprometido sugere que essa população celular se insinua através dos interstícios do estroma endometrial para promover sua progressão invasiva.

8. A manutenção de um limite definido de endométrio decidualizado com vasos sangüíneos íntegros sugere um controle eficaz do organismo materno em limitar a progressão da invasão tanto do sinciciotrofoblasto quanto do trofoblasto gigante na paca.

9. A intensa atividade proliferativa e as características ultra-estruturais do citotrofoblasto das lamelas sugerem que essas células sejam potenciais células indiferenciadas, capazes de dar origem a outras populações de células trofoblásticas presentes na placenta da paca.

10. A integração da vascularização entre a subplacenta e a placenta principal sugere a ocorrência de uma circulação portal de controle fetal. 
Referências 


\section{REFERÊNCIAS}

AMARANTE-PAFFARO, A.; QUEIROZ, G. S.; CORREA, S. T.; SPIRA, B.; BEVILACQUA, E. Phagocytosis as a potential mechanism for microbial defense of mouse placental trophoblast cells. Reproduction, v. 128, p. 207-218, 2004.

AMOROSO, E. C. Placentation. In: PARKERS, A. S. Marshall's physiology of reproduction. Londres: Longmans, 3. ed. 1952. v. 2I. p. 128, 272-274.

BENIRSCHKE, K.; KAUFMANN, P. The pathology of the human placenta. 4th ed. Springer-Verlag, NY, 2000.

BEVILACQUA, E. M. A. F.; ABRAHANSOHN, P. A. Trophoblast invasion during implantation of the mouse embryo. Archivos de Biologia y Medicina Experimentales, v. 22, p. 107-118, 1989.

BEVILACQUA, E. M. A. F.; ABRAHANSOHN, P. A. Ultrastructure oftrophoblast giant cell transformation during the invasive stage of implantation of the mouse embryo. Journal of Morphology, v. 198, p. 341-351, 1988.

BILLINGTON, W. D. Biology of the trophoblast. Advances in Reproductive Physiology. v. 5, p. 27-66, 1971. 
BILLINGTON, W. D. Organization, ultrastructure and histochemistry of the placenta: immunological considerations. In: EDWARDS, R. G.; HOWE, C. W. S.; JOHNSON, M. H. (Ed.). Immunology of trophoblast. Cambridge, U.K.: University Press, 1975, p. 6685.

BLANKENSHIP, T. N.; ENDERS, A. C.; KING, B. F. Trophoblastic invasion and modification of uterine veins during placental development in macaques. Cell and Tissue Research, v. 274, n. 1, p. 135-144, 1993.

BONATELLI, M.; CARTER, A. M.; MACHADO, M. R.; OLIVEIRA, M. F.; LIMA, M. C.; MIGLINO, M. A. Placentation in the paca (Agouti paca L). Reproductive Biology and Endocrinology. $\quad$ v. 3, 2005. Disponível em : < http://www. pubmedcentral.nih.gov/articlerender.fcgi?tool=pubmed\&pubmedid=1573723 4>.

BONATELLI, M.; MACHADO, M. R. F.; CRUZ, C; MIGLINO, M A. Análise morfológica da placenta da paca (Agouti paca, Linnaeus, 1766: Estudo ao microscópio de luz e à microscopia eletrônica de transmissão. Brazilian Journal Veterinarian Research Animal Science, v. 38, n. 5, p. 224-228, 2001.

BOSCO, C. B.; DIAZ, S. V.; BORAX, J. P. Sincíciotrofoblasto em placenta de termino de octodon degus. Estudio ultramicroscópico de transmission y barrido. Revista Chilena de Obstetrícia y Ginecologia, v. 64, n. 4, p. 249-256, 1997.

CALUWAERTS, S.; VERCRUYSSE, L.; LUYTEN C.; PIJNENBORG, R. Endovascular trophoblast invasion and associated structural changes in uterine spiral arteries of the pregnant rat. Placenta, 2005. (In Press). Disponível em:

http://www.sciencedirect.com/science?_ob=IssueURL\&_tockey=\%23TOC $\% 236988 \% 23$ 9999\%23999999999\%2399999\%23FLĀ\%23Articles_in_Press\&_auth=y\&view=c\&_acct $=$ C000050221\&_version=1\&_urlVersion=0\&_userid $=\overline{10} \& \mathrm{md} 5=4 \overline{\mathrm{e}} 63 \mathrm{e} 7 \mathrm{~b} 4 \mathrm{f} 4 \mathrm{aefcb} 9 \overline{7} \overline{\mathrm{f}} 05$ fd94c04007>. 
CARTER, A. M.; TANSWELL, B.; THOMPSON, K.; HAN, V. K. M. Immunohistochemical identification of epithelial and mesenchymal cell types in the chorioallantoic and yolk sac placentae of the guinea-pig. Placenta, v. 19, n. 7, p. 489-500, 1998.

CLARK, J. D.; OLFERT, E. D. Rodents (Rodentia). In: FOWLER, M. E. Zoo \& wild animal medicine. 2. ed. Philadelphia: W. B. Saunders, 1986. p. 728-737.

COOP, A. J. Interaction between inner cell mass and trophectoderm of the mouse blastocyst (the fate of the polar trophectoderm) Journal of Embryology and Experimental Morphology, v. 5, p.109-120, 1979.

DAVIES, J.; DEMPSEY, E. W.; AMOROSO, E. C. The subplacenta of the guinea pig: an electron microscopic study. Journal of Anatomy, v. 95, n. 4, p.311-324, 1961a.

DAVIES, J.; DEMPSEY, E. W.; AMOROSO, E. C. The subplacenta of the guinea pig: development, histology and histochemistry. Journal of Anatomy, v. 95, n. 4, p.457-473, $1961 \mathrm{~b}$.

DAVIS, J.; HESSELDAHL, H. Comparative embryology of mammalian Blastocyst. In:BLANDAU, R. J. (Ed). Biology of blastocyst. London: The University of Chicago Press, 1971. p. 27-44. 
ENDERS, A. C.; KING, B. F. Early stages of trophoblastic invasion of the maternal vascular system during implantation in the macaque and baboon. American Journal of Anatomy, v. 192, p. 329-346, 1991.

ENDERS, A. C.; WELSH, A. O. Structural interactions of trophoblast and uterus during hemochorial placenta formation. Journal Experimental Zoology, v. 266, p. 578-587, 1993.

FISCHER, T. V. The subplacenta of the beaver (Castor Canadensis). Placenta, v. 6, n. 4, p. 311-321, 1985.

FISCHER, T. V. e FLOYD A. D. Placental developmentin the mongolian gerbil (Meriones unguiculatus). II. From the establishment of the labyrinth to term. American Journal of Anatomy. n. 3, v. 134, p. 321-336, 1972.

GAGIOTI, S.; SCAVONE, C.; BEVILACQUA E, M. A. F. Participation of the mouse implanting trophoblast in nitric oxide production during pregnancy. Biology of Reproduction, v. 62, p. 260-268, 2000.

GARDNER, R. L.; PAPAIONNOU, V. E.; BARTON, S. C. Origin of the ectoplacental cone and secundary giant cells in mouse blastocysts reconstituted from isolated trophoblast and inner cell mass. Journal Embriology and Experimental Zoology, v. 30, p. 561-570, 1973.

GRAHAM, C. H.; LALA, P. K. Mechanism of placental invasion of the uterus and their control. Biochemistry and Cell Biology, v. 70, p. 867-874, 1992. 
GROH, V.; MAYERSBACH, H. Enzymatic and functional heterogeneity of lysosomes. Cell and Tissue Research, v. 214, p. 613-621, 1981.

GROSSER (1927) apud AMOROSO (1952).

HILLEMANN, H. H.; GAYNOR, A. I. The definitive architeture of the placenta of nutria, Myocastor coypus (MOLINA). The American Journal of Anatomy, v.109, n. 3, p. 299317, 1961.

HOSKEN, F. M.; SILVEIRA, A. C. Criação de pacas. Viçosa: Aprenda Fácil, 2001. 262 p. (Coleção animais silvestres; v.3).

HUNT, J. S.; MILLER, L.; VASSMER, D.; CROY, B. A. Expression of the inducible nitric oxide synthase gene in mouse uterine leukocytes and potential relationships with uterine function during pregnancy. Biology of Reproduction, v. 57, p. 827-836, 1997.

HUPPERTZ, B.; FRANK, H. G.; REISTER, F.; KINGDOM, J.; KORR, H.; KAUFMANN, P. Apoptosis cascade progresses during turnover of human trophoblast: analysis of villous cytotrophoblast and syncytial fragments in vitro. Laboratory Investigation, v. 79, p. 1687-1702, 1999.

KAKUI, K.; SAGAWA, N.; ITOH, H.; YURA, S.; KORITA, D.; TAKEMURA, M.; NUAMAH, M. A.; FUJII, S. Expression of nitric oxide synthase isoforms in the human placenta is not altered by labor. Endocrine Journal, v. 50, p. 535-544, 2003. 
KANAI-AZUMA, M.; KANAI, Y.; KUROHMARU, M.; TACHI, C.; YAZAKI, K.; HAYASHI, $\mathrm{Y}$. Giant cell transformation of trophoblast cells in mice. Endocrine Journal, v. 41, p. 33-41, 1994. Supplement.

KATZ, S.; ABRAHAMSOHN,P. A. Involuction of the antimesometrialdecidua in the mouse. An ultrastructural study. Anatomy and Embriology. V. 176, p. 251-258, 1987.

KAUFMANN, P. Capybara - Hydrochaeris hydrochaeris. In: BENIRSCHKE, K. Comparative Placentation. Disponível em: http://medicine.ucsd.edu/cpa/capy.htm. Acesso em: 20 jun. 2003.

KAUFMANN P. Guinea pig Cavia porcellus. In: BENIRSCHKE, K. Comparative Placentation. Disponível em: http://medicine.ucsd.edu/cpa/. Acesso em: 13 Aug. 2004.

KAUFMANN, P.; DAVIDOFF, M. The guinea pig placenta. Advances in Anatomy Embriology and Cell Biology, v. 53, n. 2, p. 5-90, 1977.

KING, B. F.; TIBBITTS, F. D. The fine structure of the chinchilla placenta. The American Journal of Anatomy, v. 145, p. 33-56, 1976.

KIRBY, D. R. S. The transplantation of mouse eggs and trophoblast to extra uterine sites: In: DANIEL Jr., J.C. (Ed.). Methods in mammalian reproduction. San Francisco: W.H. Freeman \& Co., 1971. p. 146-156. 
KLEIMAN, D. G.; EISENBERG, J. F.; MALINIAK, E. Reprodutive parameters and productivity of Caviomorph Rodents. In: EISENBERG, J. F. Vertebrate ecology in the northern neotropics. Washington: Smithsonian Institution, 1980. p. 173-183.

LEISER, R.; KAUFMANN, P. Placental structure: in a comparative aspect. Experimental and Clinical Endocrinology, v. 102, n. 3, p.122-134, 1994.

MATAMOROS, Y.; PASHOV, B. Ciclo estral del tepezcuinte (Cuniculus paca, Brisson) en cautiverio. Brenesia, San Jose, v. 22, p. 249-260, 1982.

MEHROTRA, P. K. Blastocyst attachment and morphogenesis of ectoplacental cone in mouse. Journal of Biosciences, v. 6, p. 43-52, 1984.

MEHROTRA, P. K. Ultrastructure of mouse ectoplacental cone cells. Biological Structures and Morphogenesis, v. 1, p. 63-68, 1988.

MERITT, D. A. The husbandry and management of the paca (Cuniculus paca) at Lincoln Park Zoo, Chicago. International Zoo Yearbook, London, n. 28, p. 264-267, 1989.

MESS, A. Evolutionary transformations of chorioallantoic placental characters in Rodentia with special reference to hystricognath species. Journal of Experimental Zoology. Part A, Comparative Experimental Biology, v. 299, n. 1, p. 78-98, 2003.

MIGLINO, M. A.; CARTER, A. M.; AMBROSIO, C. E.; BONATELLI, M.; OLIVEIRA, M. F.; SANTOS FERRAZ, R. H.; RODRIGUES, R. F.; SANTOS T. C. Vascular Organization of the Hystricomorph Placenta: a Comparative Study in the Agouti, Capybara, Guinea Pig, Paca and Rock Cavy. Placenta, v. 25, n. 5, p. 438-448, 2004. 
MIGLINO, M. A.; CARTER, A. M.; FERRAZ, R. H. S.; MACHADO, M. R. F. Placentation in the capybara (Hidrochaerus hydrochaeris), agouti (Dasyprocta agouti) and paca (Agouti paca). Placenta, v. 23, p. 416-428, 2002.

MINOT, 1889 apud AMOROSO, 1952.

MONDOLFI, E. La laca o Paca. Defensa de la Naturaleza, Caracas, v. 2, n. 5, p. 4-16, 1972.

MOSSMAN, H. W. Vertebrate fetal membranes. New Brusnwich, Rutgers Univ. Press, 1987, 383p.

MÜNTENER, M.; HSU, Y. C. Development of trophoblast and placenta in the mouse. Acta Anatomica, v. 98, p. 241-252, 1977.

MURAKAMI, T.; IKEBUCHI, Y.; OHTSUKA, A.; KIKUTA, A.; TAGUCHI, T.; OHTANI, O. The blood vascular wreath of rat ovarian follicle, with special reference to its changes inovulation and luteinization: a scanning electron microscopic study of corrosion casts. Archives of Histology and Cytology, v. 51, p. 299-313, 1988.

NANAEV, A.; CHWALISZ, K.; FRANK, H. G.; KOHNEN, G.; HEGELE-HARTUNG, C.; KAUFMANN, P. Physiological dilation of uteroplacental arteries in the guinea pig depends on nitric oxide synthase activity of extravillous trophoblast. Cell and Tissue Research, v. 282, p. 407-421, 1995.

NANAEV, A. K.; KOSANKE, G.; REISTER, F.; KEMP, B.; FRANK, H. G.; KAUFMANN, $P$. Pregnancy-induced de-differentiation of media smooth muscle cells in uteroplacental arteries of the guinea pig is reversible after delivery. Placenta, v. 21, p. 306-312, 2000. 
NOGUEIRA, T. M. R. Alguns parâmetros fisiológicos e reprodutivos da paca (Agouti paca, LINNAEUS, 1966), em cativeiro, 1997. 131f. Dissertação (Mestrado) Faculdade de Ciências Agrárias e Veterinárias, Universidade Estadual Paulista. Jaboticabal.

ODUOR-OKELO, D. An eletron microscopic study of the chorioallantoic placenta and the subplacenta of the cane rat (Thryonomys swinderianus Temminck). Placenta, v. 5, p. 433-442, 1984.

ODUOR-OKELO, D.; GOMBE, S. Placentation in the cane rat (Thryonomysswinderianus). African Journal of Ecology, v. 20, p. 49-66, 1982.

OGANDO, D. G.; PAZ, D.; CELLA, M.; FRANCHI, A. M. The fundamental role of increased production of nitric oxide in lipopolysaccharide-induced embryonic resorption in mice. Reproduction, v. 125, p. 95-110, 2003.

OLIVEIRA, F. S. Diagnóstico e acompanhamento ultra-sonográfico da prenhez em pacas (Agouti paca, Linnaeus, 1766), 2001. Dissertação (Mestrado) - Faculdade de Ciências Agrárias e Veterinárias, Universidade Estadual Paulista. Jaboticabal.

OLIVEIRA, F. S.; TONIOLLO, G. H.; MACHADO, M. R. F. Hemiovariossalpingohisterectomia em pacas prenhes e posterior ocorrência de prenhez (Agouti paca, Linnaeus, 1766). Ciência Rural, v. 33, n. 3, p. 547-551, 2003.

OLIVEIRA, M. F.; CARTER, A. M.; BONATELLI, M., AMBROSIO, C. E.; MIGLINO, M. A. Placentation in the Rock Cavy, Kerodon rupestris (Wied). Placenta, 2005. (In Press).

Disponível em: <

http://www.sciencedirect.com/science?_ob=IssueURL\&_tockey=\%23TOC\%236988\%23 9999\%23999999999\%2399999\%23FLĀ\%23Articles_in_Press\&_auth=y\&view=c\&_acct $=$ C000050221\&_version=1\&_urlVersion $=0$ \&_userid $=\overline{10} \& \mathrm{md} 5=4 \overline{\mathrm{e}} 63 \mathrm{e} 7 \mathrm{~b} 4 \mathrm{f} 4 \mathrm{aefcb} 9 \overline{7} \overline{\mathrm{f}} 05$ fd94c04007>.

PERROTA, C. A. Fetal membranes of the canadian porcupine, Erithizon dorsatum. The American Journal of Anatomy, v. 104, p. 35-59, 1959. 
PERRY, J. S. The mammalian fetal membranes. Journal of Reproduction and Fertility, v. 62, n. 2, p. 321-335, 1981.

POLLEIMER, J.; KNOFLER, M. Signaling pathways regulating the invasive differentiation of human trophoblasts: a review. Placenta, v. 26, n. 1, p. 21-30, 2005.

PURCELL, T. L.; BUHIMSCHI, I. A.; GIVEN, R.; CHWALISZ, K.; GARFIELD, R. E. Inducible nitric oxide synthase is present in the rat placenta at the fetal-maternal interface and decreases prior to labour. Molecular Human Reproduction. v. 3, p. 485491, 1997.

RAMSEY, E.M.; DONNER, M.W.: Placental Vasculature and Circulation. Anatomy, Physiology, Radiology, Clinical Aspects. Atlas and Textbook. W.B. Saunders Company, Philadelphia, 1980.

REALDUS COLUMBUS (1516-1559) apud AMOROSO (1952)

ROBERTS C. M.; PERRY J. S. Hystricomorph Embryology. Symp. Zool. Soc. Lond. v. 34, p. $333-360,1974$.

SCHLAFKE, S.; ENDERS, A. C. Cellular basis of interaction between trophoblast and uterus at implantation. Biology of Reproduction, v. 12, p. 41-65, 1975.

SMITHE, N. The paca. In: ROBINSON, J. G.; REDFORD, K. H. Microlivestock: little known small animals with promising economic future. Washington: National Academy. 1991. p. 263-269. 
SNELL, G. G.; STEVENS, L. C. Early embryology. In: Biology of laboratory mouse. Ed. E. L. Green. New York, McGraw Hill, 1966. p.205-245.

SOIRON, M. L. Das Siidamerikanische wasserschwein (Hydrochoerus hydrochaeris, L. 1766). 1993. 133 f. Tese (Doutorado) - Fachbereich Veterinãrmedizin, Justus- Liebig-Universitãt Giessen, Giessen, 1993.

STARCK, D. Ueber die Länge der Nabelschnur bei Säugetieren. Z. Säugetierk. v. 22, p. 77-86, 1957.

STEVENS, D. H. Interspecies differences in the culture and function of trophobalst. In: LOKE, Y. W.; WHITE, A. Biology of trophoblast. Amsterdam, Elsevier, 1983. p. 111136.

TACHI, C.; TACHI, S.; LINDNER, H. R. Ultrastructural features of blastocyst attachment and trophoblastic invasion in the rat. Journal of Reproduction and Fertility, v. 21, p. 37-56, 1970.

TIBBITTS, F. D.; HILLEMANN, H. H. The development and histology of the chinchilla placentae. Journal of Morphology, v. 105, p. 317-365, 1959.

UHLENDORF, B.; KAUFMANN, P. Die entwicklung des plazentastieles beim meerschweinchen. Zbl. Vet. Med. C. Anat. Histol. Embryol, v. 8, p. 233-247, 1979.

WIMSATT, W. A. Some aspects of the comparative anatomy of the mammalian placenta. American Journal of Obstetric and Ginecology, v. 1, p. 1568-1594, Dec. 
1962.

WIMSATT, W. A. Some comparative aspects of implantation. Biology of Reproduction, v. 12, n. 1, p. 1-40, 1975.

WOLFER, J.; KAUFMANN, P. Die ultrastruktur der meerschweinchen-subplazenta. Zbl. Vet. Med. C. Anat. Histol. Embryol. v. 9, p. 29-43, 1980. 
Apêndice A 


\title{
Reproductive Biology and Endocrinology
}

This Provisional PDF corresponds to the article as it appeared upon acceptance. The fully-formatted PDF version will become available shortly after the date of publication, from the URL listed below.

\section{Placentation in the paca (Agouti paca L)}

Reproductive Biology and Endocrinology2005, 3:9 doi:10.1186/1477-7827-3-9

Marina Bonatelli (miglino@usp.br)

Anthony M Carter (acarter@ health.sdu.dk)

Marcia R Fernandes Machado (mrfmachd@ fcav.unesp.br)

Moacir F De Oliveira (mfranco@esam.br)

Marcelo Cardoso de Lima (miglino@usp.br)

Maria Angelica Miglino (miglino@usp.br)

\author{
ISSN $1477-7827$ \\ Article type Research \\ Submission date 1 Dec 2004 \\ Acceptance date $28 \mathrm{Feb} 2005$ \\ Publication date 28 Feb 2005 \\ Article URL http://www.rbej.com/content/3/1/9
}

This peer-reviewed article was published immediately upon acceptance. It can be downloaded, printed and distributed freely for any purposes (see copyright notice below).

Articles in Reproductive Biology and Endocrinology are listed in PubMed and archived at PubMed Central. For information about publishing your research in Reproductive Biology and Endocrinology or any BioMed

Central journal, go to

http://www.rbej.com/info/instructions/

For information about other BioMed Central publications go to

http://www.biomedcentral.com/

2005 Bonatelli et al., licensee BioMed Central Ltd.

This is an Open Access article distributed under the terms of the Creative Commons Attribution License (http://creativecommons.org/licenses/by/2.0), which permits unrestricted use, distribution, and reproduction in any medium, provided the original work is properly cited. 


\section{Placentation in the paca (Agouti paca L)}

Marina Bonatelli ${ }^{1}$, Anthony M Carter ${ }^{2} *$, Marcia R Fernandes Machado ${ }^{3}$, Moacir F De

Oliveira $^{4}$, Marcelo Cardoso de Lima ${ }^{1}$, Maria Angelica Miglino ${ }^{1}$

Address: ${ }^{1}$ Department of Surgery, School of Veterinary Medicine, University of Sao Paulo, Sao Paulo, Brazil

${ }^{2}$ Department of Physiology and Pharmacology, University of Southern Denmark, Odense,

Denmark

${ }^{3}$ Paulista State University, Jaboticabal, Sao Paulo, Brazil

${ }^{4}$ Mossoró Superior School of Agriculture, Rio Grande do Norte, Brazil.

Email: Anthony M Carter*, acarter@health.sdu.dk

*Corresponding author 


\begin{abstract}
Background: The paca is a South American rodent with potential as a commercial food animal. We examined paca placenta as part of a wider effort to understand the reproductive biology of this species.
\end{abstract}

Methods: Thirteen specimens between midgestation and term of pregnancy were studied by light and transmission electron microscopy.

Results: The placenta is divided into several lobes separated by interlobular trophoblast. Maternal arterial channels and fetal veins are found at the centre of each lobe. In the labyrinth, maternal blood flows through trophoblast-lined lacunae in close proximity to the fetal capillaries. The interhaemal barrier is of the haemomonochorial type with a single layer of syncytiotrophoblast. Caveolae occur in the apical membrane of the syncytiotrophoblast and recesses in the basal membrane, but there is no evidence of transtrophoblastic channels. The interlobular areas consist of cords of syncytiotrophoblast defining maternal blood channels that drain the labyrinth. Yolk sac endoderm covers much of the fetal surface of the placenta. The subplacenta comprises cytotrophoblast and syncytiotrophoblast. There are dilated intercellular spaces between the cytotrophoblasts and lacunae lined by syncytiotrophoblast. In the junctional zone between subplacenta and decidua, there are nests of multinucleated giant cells with vacuolated cytoplasm. The entire placenta rests on a pedicle of maternal tissue. An inverted yolk sac placenta is also present. The presence of small vesicles and tubules in the apical membrane of the yolk sac endoderm and larger vesicles in the supranuclear region suggest that the yolk sac placenta participates in maternal-fetal transfer of protein.

Conclusions: The paca placenta closely resembles that of other hystricomorph rodents. The lobulated structure allows for a larger exchange area and the development of precocial young.

\title{
Introduction
}

The paca (Agouti paca, L) is a South American rodent that lives in forested habitats near water and feeds largely on fallen fruit. It is hunted for its meat, which is considered a delicacy, and is an important source of animal protein for rural populations. This has led to 
indiscriminate exploitation, resulting in a significant reduction in the population density of this species in Brazil.

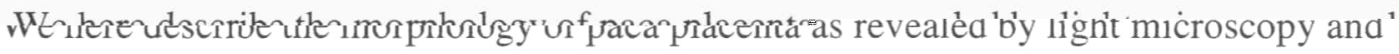
transmission electron microscopy. This study is part of a wider effort to document the reproductive physiology of paca. It is hoped that the information obtained will contribute to a rational strategy for conservation of the species and possibly for production, as paca has great potential as a commercial food animal [1].

\section{Materials and Methods}

The observations are based on placentae collected from 13 pregnant females. One was in early gestation, two in midgestation and nine near term of pregnancy. This material was collected at Paulista State University, Jaboticabal, Sao Paulo, Brazil. The research was authorized by the Brazilian Institute of the Environment and Renewable Natural Resources (IBAMA). The experimental protocol was approved by the Bioethics Committee of the School of Veterinary Medicine, University of Sao Paulo.

The animals were sedated with azaperone (Stresnil, Janssen Pharmaceutica, Brazil; 0.1 $\mathrm{mg} / \mathrm{kg}$ I.M.) and given atropine (0.5 mg I.M.). Anaesthesia was induced with xylazine (Coopazine, Coopers Brazil, Sao Paulo, S.P., Brazil; 1.5 mg/kg I.M.) and ketamine (Holliday Scott S.A., Brazil; 20 mg/kg I.M.). Hemihysterectomy was then performed under aseptic conditions during inhalation anaesthesia with halothane (Hoechst, Frankfurt, Germany). Postoperatively the animals were treated with benzyl penicillin and streptomycin (Pentabiotico ${ }^{\circledR}$, Fort Dodge, Campinas, S.P., Brazil; 8,000-24,000 IU/kg I.M.) and an analgetic (buprenorphine, Temgesic ${ }^{\circledR}$, Schering-Plough, S.P., Brazil). A detailed description of the anaesthesia and surgical procedures has been published elsewhere [2].

Pieces of ten placentae were fixed in Bouin's solution or $10 \%$ formaldehyde and processed by standard histological procedures for embedding in paraplast, then sectioned at $7 \mu \mathrm{m}$ (automatic microtome, Model RM2155, Leica, Germany). Sections were stained with 
haematoxylin and eosin, Masson's trichrome or Gomori's trichrome or by the periodic acid Schiff (PAS) reaction with haematoxylin as counterstain.

Seven placentae were processed for transmission electron microscopy. Small samples were fixed in $2.5 \%$ glutaraldehyede in $0.1 \mathrm{M}$ phosphate buffer, $\mathrm{pH} 7.4$, washed in buffer and post-fixed in $1 \%$ osmium tetroxide (Polysciences, Warrington, PA, USA). They were then dehydrated, washed with propylene oxide and embedded in Spurr's resin (Spurr's Kit, Electron Microscopy Sciences, CO, U.S.A.). $60 \mathrm{~nm}$ sections were made and stained with $2 \%$ uranyl acetate (5 minutes) and $0.5 \%$ lead citrate (10 minutes). The ultrastructural observations were made with a transmission electron microscope (JEOL 1010, Peabody, MA, U.S.A).

\section{Results}

The overall plan of the paca placenta is shown schematically in Figure 1. The labyrinth is divided into lobes separated by interlobular trophoblast. Beneath this is the subplacenta, a structure unique to hystricomorph rodents. The junctional zone between these structures and the maternal decidua contains nests of giant cells. The placenta is attached to the uterus by a pedicle of maternal tissue. In addition, there is an inverted yolk sac placenta, which connects with the fetal surface of the chorioallantoic placenta.

\section{Histology}

The centres of the lobes, the labyrinth and the interlobular regions are clearly defined (Figure 2A). The central region of each lobe contains fetal and maternal vessels around which there is a considerable quantity of connective tissue (fetal mesenchyme; Figure 2B). The vessels carrying maternal arterial blood lack endothelium and they are lined by trophoblast cells (Figure 2C).

The most extensive portion of the lobe is the labyrinth. Due to close proximity between maternal and fetal blood vessels, it is the region where most maternal-fetal exchange takes place. The maternal blood spaces or lacunae are not lined by endothelium; they are defined 
by trophoblastic cell columns or cords. The cell columns are radially arranged as is apparent when the lobe is seen in cross section (Figure 2D). The syncytial nature of the trophoblastic columns is indicated by the close proximity of their nuclei.

The interlobular regions comprise cords of syncytiotrophoblast with abundant basophilic cytoplasm. These cords define maternal blood channels. The channels converge upon larger blood spaces, still without an endothelial lining, that receive blood from two or more adjacent lobes. Thus, each interlobular region is common to several lobes (Figure $3 \mathrm{~A}$ ). The interlobular regions also contain fetal arteries (Figure 3B) that give rise to the capillaries of the labyrinth.

\section{Placental surface}

Most of the surface of the placental disk is covered by an epithelium formed by the endoderm of the parietal yolk sac (Figure 4A-C). An almost continuous Reichert's membrane can be demonstrated (Figure 4B). Beneath it is a layer of spongiotrophoblast. These cells differ from those that occur in the marginal and interlobular trophoblast. They are larger in size and have a rounded and vacuolated appearance (Figure 4C). The centre of the fetal surface of the placenta, including the attachment of the cord, is covered by a layer of connective tissue (Figure 4D).

\section{Subplacenta, junctional zone and pedicle}

The subplacenta is organized as folded lamellae of cytotrophoblasts supported on a thin layer of mesenchyme carrying fetal vessels (Figure 5A). The cytotrophoblast is multilaminar and mitotic figures are common here in early and midgestation. Beneath this layer is syncytiotrophoblast, which contains vacuoles and PAS-positive material. In late gestation this region becomes more compact and the entire subplacenta undergoes a process of degeneration.

Groups of giant cells are found in the junctional zone between the subplacenta and decidua (Figure 5B). They are multinucleated and have a finely granular, basophilic cytoplasm. They are PAS-positive. 
The placenta is attached to the uterus by a placental pedicle made up of uterine tissue. In the upper region of this pedicle, a fine and discontinuous layer of connective tissue is interposed between the maternal tissue and fetal trophoblast. In the middle portion of the pedicle, a large number of vessels pass to or from the placenta. This region is characterized by dense fibres of connective tissue externally and of looser connective tissue around the vessels (Figure 5C). A layer of squamous epithelial cells with simple, round nuclei, lightly condensed chromatin and clear cytoplasm covers the entire pedicle (not shown).

\section{Yolk Sac Placenta}

There is an inverted yolk sac placenta, which is attached to the fetal surface of the chorioallantoic placenta. Just before attachment it forms the fibrovascular ring (Figure 4A). The yolk sac exhibits numerous digitiform projections (Figure 6A), which sometimes are branched. They consist of a mesenchymal core covered by a layer of endoderm. The latter forms a simple columnar epithelium of cells with apically situated cell nuclei (Figure 6B).

\section{Ultrastructure}

The paca placenta is of the syncytial haemomonochorial type. A single trophoblast layer can be identified between the blood in the maternal blood spaces of the labyrinth and the endothelium of the fetal capillaries (Figure 7A-B). This trophoblast is syncytial in nature without cell boundaries and with large nuclei, often in close proximity to one other. Microvilli project from the apical membrane into the maternal blood space. Caveolae are seen in the apical membrane and the syncytiotrophoblast contains coated vesicles and larger vacuoles. There are recesses in the basal membrane. However, we saw no evidence of transtrophoblastic channels. There is an abundant amount of rough endoplasmic reticulum, a Golgi apparatus, lysosomes and numerous mitochondria.

In the interlobular areas, the syncytiotrophoblast bordering the maternal blood spaces has numerous microvilli (Figure 7C). The cytoplasm has abundant rough endoplasmic reticulum, mitochondria and electron-dense droplets. Cytotrophoblast cells occur within the 
syncytium. Desmosomes are present between adjacent cytotrophoblast cells as well as between cytotrophoblasts and the overlying syncytium.

The cells of the parietal yolk sac endoderm form a columnar epithelium (Figure 7D). These cells are irregular in shape with basally situated nuclei. The apical membrane, which faces the uterine lumen, has microvilli and caveolae. The supranuclear cytoplasm contains vacuoles and vesicles, tubular mitochondria and rough endoplasmic reticulum.

Desmosomes are found between the lateral membranes of adjacent cells.

\section{Subplacenta and junctional zone}

The cytotrophoblast layer is multilaminar with dilated intercellular spaces (Figure 8A). The cytoplasm of the syncytium has mitochondria, rough endoplasmic reticulum, numerous electron-dense granules (Figure 8B) and large accumulations of electron-dense material. The cytoplasm has electron transparent patches, which gives it a vacuolated appearance. There are lacunae within the syncytiotrophoblast, lined by microvilli and containing material of moderate electron density (Figure 8B). Desmosomes occur between adjacent cytotrophoblast cells and between the plasma membranes of these cells and that of the syncytial trophoblast.

In the junctional zone between the decidua and the lateral aspect of the subplacenta, there are nests of multinucleated giant cells (Figure $8 \mathrm{C}$ ). Their morphology is variable. The cytoplasm has extensive electron transparent areas. The organelles tend to be confined to the perinuclear and marginal areas (Figure 8D) and include mitochondria, rough endoplasmic reticulum and electron-dense granules. The giant cells are separated by electron-dense material into which they send processes (Figure 8D).

\section{Yolk sac placenta}

The apical surface of the endoderm cells has numerous microvilli of relatively uniform length (Figure 9A). Small vesicles and tubules are present in the most apical regions of the cytoplasm (Figure 9B). The supranuclear cytoplasm contains a number of larger vesicles and vacuoles with a variable amount of electron-dense content. The perinuclear cytoplasm also houses a small Golgi complex. The cytoplasm has mitochondria and rough 
endoplasmic reticulum. Desmosomes and terminal bars are present between the lateral membranes of the cells.

\section{Discussion}

As in other hystricomorph rodents [3-4], the placenta of paca consists of several lobes separated by interlobular trophoblast. The center of each lobe contains maternal arteries from which blood flows to the periphery through the trophoblastic channels of the labyrinth. In the fetal capillaries, blood flows from the periphery towards the center, allowing for countercurrent exchange [5-6]. The interlobular regions are made up of cords of syncytiotrophoblast, which define maternal blood spaces. We show here that each interlobular region drains several lobes.

In the labyrinth, the trophoblast is bathed directly by maternal blood and is separated from the fetal capillaries by a single layer of syncytiotrophoblast. Thus the placental barrier is syncytial haemomonochorial, as in the guinea pig [7-9], chinchilla [10], cane rat [11], degu [12] and rock cavy [13]. The apical membrane of this trophoblast, which is in contact with maternal blood, is well supplied with microvilli. There are recesses in the basal membrane and caveolae can occasionally be seen at the apical membrane. However, we did not observe transtrophoblastic channels such as those described in the degu [12].

In the interlobular region, the trophoblast contained mitochondria and rough endoplasmic reticulum. The surface in contact with maternal blood bore numerous microvilli. The interlobular trophoblast is the functional equivalent of the spongy zone of murid rodents [14]. In the guinea pig it has been identified as the principal site of progesterone synthesis [15]. In addition, it is thought to synthesize progesterone-binding protein [16], which is found in the plasma throughout gestation and is unique to hystricomorph rodents.

Much of the surface of the placental disk is covered by the endoderm of the parietal yolk sac. This epithelium is largely columnar and rests on Reichert's membrane. Beneath the membrane are trophoblast cells that differ from those in other regions of the placenta in their larger size, rounder form and vacuolated appearance. An appropriate designation for 
these cells is spongiotrophoblast. It has been shown in the guinea pig that maternal protein can cross the spongiotrophoblast and Reichert's membrane. It can then pass into the uterine lumen through the intercellular spaces between the endoderm cells, as they are not sealed by tight junctions [17]. In theory the protein could then be taken up by the visceral yolk sac, but whether maternal-fetal exchange occurs by this circuitous route is open to speculation.

The subplacenta is a unique feature of hystricomorph rodents [3]. Characteristic of the subplacenta of paca were the large intercellular spaces between the cytotrophoblasts and the lacunae within the syncytiotrophoblast. As in the guinea pig [18] and chinchilla [10], the lacunae in the syncytium were lined by microvilli and contained electron-dense material. It seems likely that the lacunae intercommunicate, but this requires further investigation.

Wolfer and Kaufmann [19] suggested that the subplacenta might be a highly active area from a metabolic point of view. They pointed out that the structure had been carefully described, but that little was known about its function, except that it might have endocrine activity. Recently it was proposed that the subplacenta is an important source of invasive trophoblast in the guinea pig, chinchilla, capybara and degu [20].

We found multinucleated giant cells in the junctional zone between the subplacenta and decidua. Intriguingly, the cytoplasm of these cells contained electron-dense granules reminiscent of those found in the subplacental syncytium. The cytoplasm of the giant cells had areas of low electron density, a feature also shared by the subplacental syncytium. These cells were PAS-positive and may store glycogen or glycoprotein.

The placenta of paca is attached to the uterus by a prominent structure, formed largely of maternal tissue, that we have denoted the placental pedicle. It was first described by Strahl [21] and named by him the mesoplacenta. A similar structure occurs in the agouti [4], chinchilla [22] and nutria [5]. The equivalent formation in the capybara and guinea pig placenta is the placental stalk [23]. Trophoblast is found in the walls of the maternal vessels that pass through the pedicle to supply the placenta [4]. 
Like other hystricomorph rodents, paca has an inverted yolk sac placenta that persists until term. This visceral yolk sac displays folds and complex villi. The numerous digitiform projections are sometimes branched. They consist of a mesenchymal axis covered by a simple columnar epithelium of endodermal cells. The cells seem to have a high level of endocytotic activity. Similar characteristics are found in the yolk sac endoderm of the guinea pig [24], chinchilla [10] and rock cavy [13]. In the guinea pig it has been shown experimentally that immunoglobulin $\mathrm{G}$ is taken up from the uterine lumen to coated pits. The endocytotic vesicles thus formed are transported to the lateral membrane and empty into the intercellular spaces by exocytosis [25]. From here the immunoglobulins are presumed to reach fetal capillaries. Protein cannot move directly into the intercellular spaces because of the tight junctions near the apex of the cells [25]. In addition to this mechanism for conferring passive immunity to the fetus, there is nonspecific uptake of protein from the uterine lumen. Many endocytotic vesicles fuse with larger vacuoles that form part of the cell's lysosomal apparatus [26]. The protein they contain is thought to provide amino acids to the fetus. Given the similarity in ultrastructure, these mechanisms are likely to operate in the yolk sac placenta of paca.

In conclusion, the placenta of the paca conforms to patterns previously described for hystricomorph rodents $[3,14]$. Common features include the lobulation of the placenta and the presence of a subplacenta. At the ultrastructural level they comprise the haemomonochorial nature of the interhaemal barrier and the pinocytotic apparatus of the visceral yolk sac endoderm. The lobulated structure of the placenta allows for a larger exchange area and the development of precocial young [14].

Recently it was argued that more attention should be given to the hystricomorph rodents as models in human medicine. They bear a closer genetic similarity to humans than do murid rodents, such as the mouse and rat, because the latter have undergone a very high rate of gene mutation [27]. Since the paca carries a singleton fetus with a birth weight of 640-900 $\mathrm{g}$, it deserves particular consideration as a potential model of fetal growth and development [28]. 


\section{Acknowledgements}

This study was supported by Fundação de Amparo à Pesquisa do Estado de São Paulo (FAPESP) and Conselho Nacional de Desenvolvimento Científico e Tecnológico (CNPq). We are grateful to Dr. Fabrício Singaretti de Oliveira (UNESP) for ultrasound examination of the animals. Marina Bonatelli wishes to thank Professors José Manoel dos Santos (FMABC), Idercio Luiz Sinhorini (USP) and Áureo Tatsumi Yamada (UNICAMP) for their guidance.

\section{References}

1. Domestication and husbandry of the paca (Agouti paca). 1995. FAO Conservation Guide No. 26. Rome, FAO.

2. De Oliveira FS, Toniollo GH, Machado MRF, Paura D: Hemiovariossalpingohysterectomy in pregnant pacas and further occurrence of pregnancy (Agouti paca, Linnaeus, 1766). Ciência Rural, Santa Maria 2003, 33: 547-551.

3. Luckett WP, Mossman HW: Development and phylogenetic significance of the fetal membranes and placenta of the African hystricognathous rodents Bathyergus and Hystrix. Comp Biochem Physiol A Mol Integr Physiol 1981, 162: 265-285.

4. Miglino MA, Carter AM, Dos Santos Ferraz RH, Fernandes Machado MR: Placentation in the capybara (Hydrochaerus hydrochaeris), agouti (Dasyprocta aguti) and paca (Agouti paca). Placenta 2002, 23: 416-428.

5. Hillemann HH, Gaynor AI: The definitive architecture of the placenta of nutria, Myocastor coypus (Molina). Am J Anat 1961, 109: 299-318.

6. Miglino MA, Carter AM, Ambrosio CE, Bonatelli M, De Oliveira MF, Dos Santos Ferraz RH, Rodrigues RF, Santos TC: Vascular organization of the hystricomorph placenta: a comparative study in the agouti, capybara, guinea pig, paca and rock cavy. Placenta 2004, 25: 438-448.

7. Enders AC: A comparative study of the fine structure of the trophoblast in several hemochorial placentas. Am J Anat 1965, 116: 29-67.

8. Kaufmann P: Electron microscopy of the guinea-pig placental membranes. Placenta 1981, Supplement 2, pp. 3-10. 
9. Kaufmann, P, Davidoff M: The guinea pig placenta. Adv Anat Embryol Cell Biol 1977, 53: 5-91.

10. King BF, Tibbitts FD: The fine structure of the chinchilla placenta. Am J Anat 1976, 145: 33-56.

11. Oduor-Okelo D: An electron microscopic study of the chorioallantoic placenta and the subplacenta of the cane rat (Thryonomys swinderianus Temminck). Placenta 1984, 5: 433-442.

12. King BF: Ultrastructural evidence for transtrophoblastic channels in the hemomonochorial placenta of the degu (Octodon degus). Placenta 1992, 13: 35-41.

13. Oliviera MF, Carter AM, Bonatelli M, Ambrosio CE, Miglino MA. Placentation in the rock cavy, Kerodon rupestris (Wied). Placenta 2005, 26: in press.

14. Mess A: Evolutionary transformations of chorioallantoic placental characters in rodentia with special reference to hystricognath species. J Exp Zoolog Part A Comp Exp Biol 2003; 299: 78-98.

15. Tam WH: Steroid synthesis in vitro by the placenta of the guinea-pig, and progesterone concentrations in systemic and uterine plasma. J Endocrinol 1977, 73: 483-489.

16. Perrot-Applanat M, David-Ferreira JF: Immunocytochemical localization of progesterone-binding protein (PBP) in guinea-pig placental tissue. Cell Tissue Res 1982, 223:627-639.

17. King BF: The permeability of the guinea pig parietal yolk sac placenta to peroxidase and ferritin. Am J Anat 1972, 134: 365-376.

18. Davies J, Dempsey EW, Amoroso EC: The subplacenta of the guinea pig: An electron microscopic study. J Anat Lond 1961, 95: 311-324.

19. Wolfer J, Kaufmann P: Die Ultrastruktur der Meerschweinchen-Subplazenta. Z Vet Med C Anat Histol Embryol 1980, 9: 29-43.

20. Kaufmann P: Guinea pig Cavia porcellus. In: Benirschke K Comparative Placentation. [http://medicine.ucsd.edu/cpa/]. Accessed 13 August 2004.

21. Strahl H: Eine Placenta mit einem Mesoplacentarium. Anat Anz 1905, 26: 524-528.

22. Tibbitts FD, Hillemann HH: The development and histology of the chinchilla placenta. J Morphol 1959, 105: 317-365. 
23. Uhlendorf B, Kaufmann P: Die Entwicklung des Plazentastieles beim Meerschweinchen. Z Vet Med C Anat Histol Embryol 1979, 8: 233-247.

24. King BF, Enders AC: The fine structure of the guinea-pig visceral yolk sac placenta. Am J Anat 1970, 127: 397-414.

25. King BF: The role of coated vesicles in selective transfer across yolk sac epithelium. J Ultrastruct Res 1982, 79: 273-284.

26. King BF, Enders AC: Protein absorption and transport by the guinea pig visceral yolk sac placenta. Am J Anat 1970, 129: 261-287.

27. Waddell PJ, Kishino H, Ota R: A phylogenetic foundation for comparative mammalian genomics. Genome Inform Ser Workshop Genome Inform. 2001; 12: 141-54.

28. Carter AM: Animal models in fetal growth and development. In: Hau J, Van Hoosier GL (Eds.) Handbook of Laboratory Animal Science, Second Edition, Volume II, pp. 41-54. Boca Raton: CRC Press, 2003. 


\section{Figure legends}

\section{Figure 1}

Schematic drawing of the paca placenta. The labyrinth is divided into lobes separated by interlobular trophoblast. Beneath it is found the subplacenta and then the decidua. There is a tenuous attachment to the uterine wall, the pedicle or mesoplacenta. An inverted yolk sac placenta is present throughout gestation.

\section{Figure 2}

The labyrinth of the paca placenta. (A) The central region of a lobe (cl), a labyrinthine region (lab) and interlobular regions (in). Haematoxylin and eosin. (B) Central region of a placental lobe, showing the presence of fetal veins (fv), maternal arterial blood spaces (ma) lined by trophoblast cells, and the mesenchyme (mes) surrounding these structures. Haematoxylin and eosin. (C) Detail to show the trophoblastic lining of maternal blood spaces (tr) and the intact walls of small fetal veins. PAS. (D) The placental labyrinth, showing the radial disposition $(\leftarrow)$ of the trophoblastic columns, the fetal capillaries (fc) and maternal blood spaces (mbs). Haematoxylin and eosin. Scale bars: $500 \mu \mathrm{m}$ (A), 200 $\mu \mathrm{m}(\mathrm{B}) ; 50 \mu \mathrm{m}(\mathrm{C}, \mathrm{D})$.

\section{Figure 3}

The interlobium of the paca placenta. (A) Channels in the interlobium (in) drain the maternal blood spaces of the labyrinth (lab) and converge on larger venous blood spaces (mv). Haematoxylin and eosin. (B) Fetal artery (fa) at the border between an interlobular region and the labyrinth at the periphery of a lobe. Haematoxylin and eosin. Scale bars: 100 $\mu \mathrm{m}(\mathrm{A}) ; 50 \mu \mathrm{m}(\mathrm{B})$.

\section{Figure 4}

Fetal surface of the paca placenta. (A) The visceral yolk sac (vys) attaches to the surface of the chorioallantoic placenta. Just before attachment it forms the fibrovascular ring (fvr). Left of the point of attachment, the endoderm continues as the parietal yolk sac (pys). To the right, the surface is covered by connective tissue. Masson's trichrome. (B) The parietal 
yolk sac endoderm (endo) forms a layer of epithelial cells that rests on Reichert's membrane $(\mathrm{Rm})$. Immediately below the membrane are scattered connective tissue cells (ct). Masson's trichrome. (C) Beneath the endoderm and Reichert's membrane are spongiotrophoblast cells ( $\mathrm{sp}$ tr), with a vacuolated appearance, marginal syncytium (ma tr) and a portion of the labyrinth (lab). Haematoxylin and eosin. (D) The centre of the placental disk is covered by connective tissue. Beneath this are marginal trophoblast and labyrinth. Haematoxylin and eosin. Scale bars: $500 \mu \mathrm{m}$ (A); $10 \mu \mathrm{m}$ (B); $100 \mu \mathrm{m}$ (C-D).

\section{Figure 5}

Subplacenta, junctional zone and pedicle of the paca placenta. (A) Subplacenta. A layer of cytotrophoblasts (cy tr) is supported on lamellae of fetal mesenchyme (fm). Beneath it is the subplacental syncytiotrophoblast (sy tr). Gomori's trichrome. (B) Groups of multinucleated giant cells with a finely granular cytoplasm are found between the subplacenta and decidua. They are bordered by connective tissue. Masson's trichrome. (C) Middle portion of the placental pedicle, showing a large number of maternal blood vessels (mbv) and connective tissue fibers (ct). Haematoxylin and eosin. Scale bars: $20 \mu \mathrm{m}$ (A-B); $200 \mu \mathrm{m}(\mathrm{C})$.

\section{Figure 6}

Yolk sac placenta of the paca. (A) The visceral yolk sac is complexly folded with columnar epithelial cells of endodermal origin (endo) supported by fetal mesenchyme (fm).

Haematoxylin and eosin. (B) The mesenchyme (stained blue) contains vitelline blood vessels (vit bv). Masson's trichrome. Scale bars: $50 \mu \mathrm{m}$ (A); $10 \mu \mathrm{m}$ (B).

\section{Figure 7}

Ultrastructure of the labyrinth, interlobium and parietal yolk sac endoderm. (A-B) The interhaemal barrier. Only a single layer of syncytiotrophoblast is interposed between the blood flowing in the maternal blood spaces (mbs) and the endothelium of the fetal capillary (fc). The apical membrane contains invaginations (arrowheads) and the cytoplasm includes small coated vesicles (cv) and larger vacuoles. There are recesses in the basal membrane (arrows). (C) Interlobium. Most of the trophoblast is syncytial (sy tr) with abundant rough 
endoplasmatic reticulum. There are many microvilli where it is in contact with the maternal blood space. Cytotrophoblast cells with large nuclei are found in some regions of the interlobium. Desmosomes are found between the lateral membranes of adjacent cells (arrowheads). (D) Parietal yolk sac endoderm. These columnar cells have numerous microvilli at the apical surface. The supranuclear cytoplasm contains vacuoles and vesicles, tubular mitochondria and rough endoplasmic reticulum. Desmosomes are found between the lateral membranes of adjacent cells (arrowheads). Scale bars: $1 \mu \mathrm{m}$ (A-B); $5 \mu \mathrm{m}$ (C); 2 $\mu \mathrm{m}(\mathrm{D})$.

\section{Figure 8}

Ultrastructure of the subplacenta and junctional zone of the paca placenta. (A) The cytotrophoblast layer (cy tr) is multilaminar with dilated intercellular spaces. The cells are characterized by their large nuclei. They rest on a thin basement membrane (bm) which separates them from the fetal mesenchyme. (B) The syncytiotrophoblast (sy tr) contains electron-dense droplets (dd). Microvilli project from the syncytiotrophoblast into lacunae containing material of moderate electron density (arrows). (C) Multinucleated giant cells from the junctional zone. The cytoplasm has electron transparent areas, giving it a vacuolated appearance. (D) Two giant cells (gc) separated by intercellular matrix into which they send processes (arrows). Scale bars: $5 \mu \mathrm{m}$ (A-C); $1 \mu \mathrm{m}$ (D).

\section{Figure 9}

Ultrastructure of the inverted yolk sac placenta of the paca. (A) The apical surface of the endodermal cells bears numerous microvilli. The supranuclear cytoplasm contains many larger vesicles or vacuoles with a small amount of electron dense content. (B) Invaginations (arrowheads), small coated vesicles (cv) and tubules are present in the most apical regions of the cytoplasm. Scale bars: $4 \mu \mathrm{m}(\mathrm{A}) ; 1 \mu \mathrm{m}$ (B). 
yolk sac

\section{labyrinth}

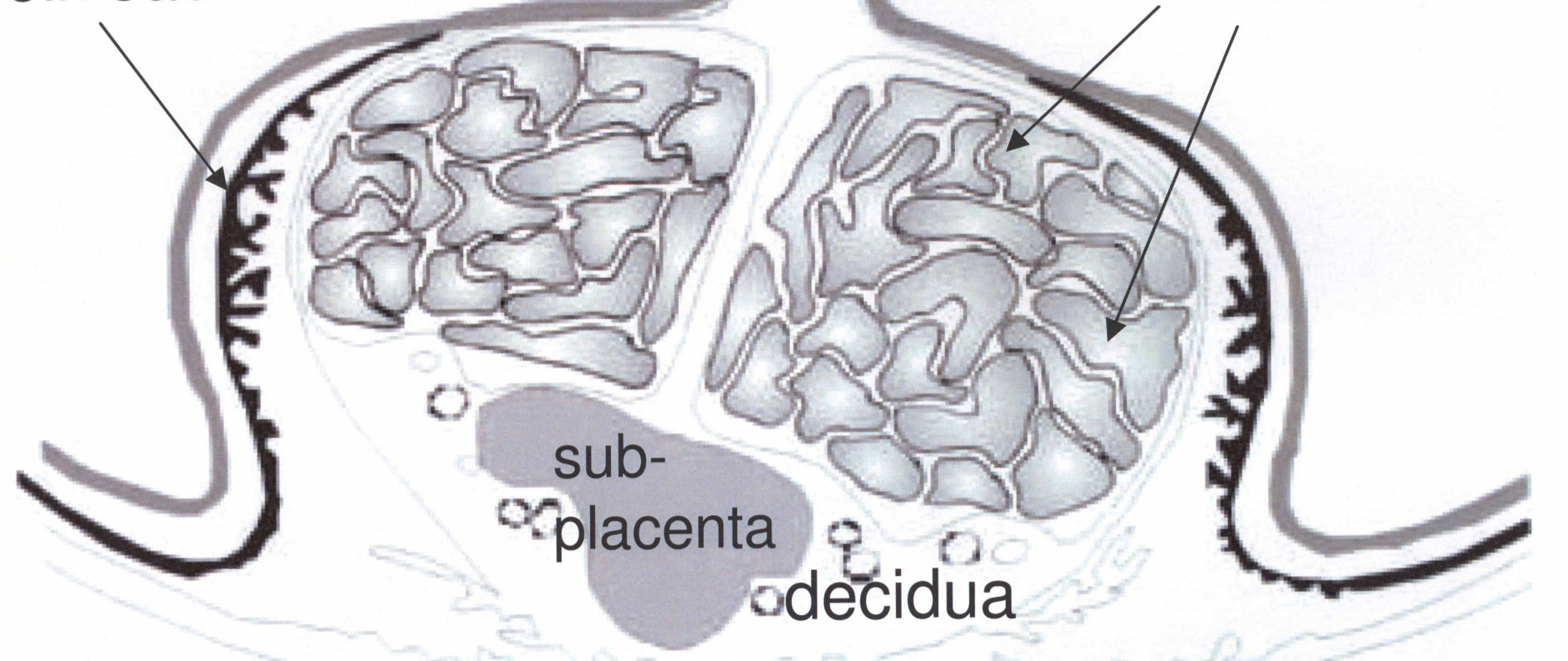

pedicle 


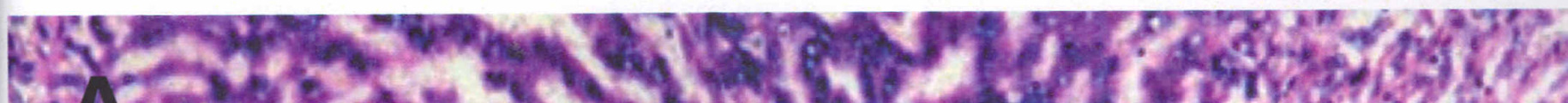

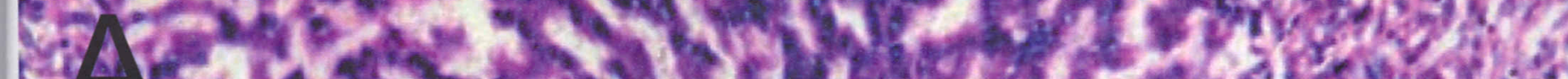

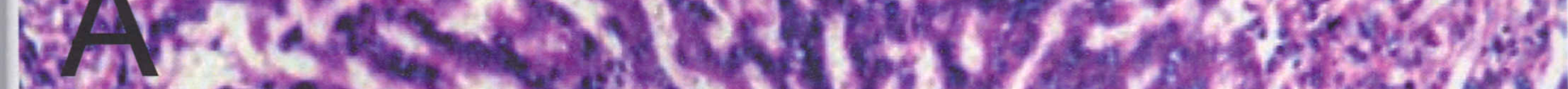

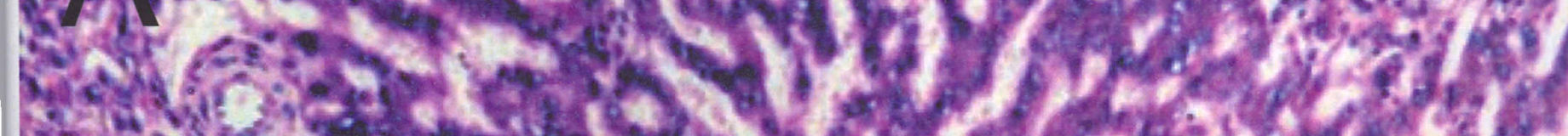
Sing

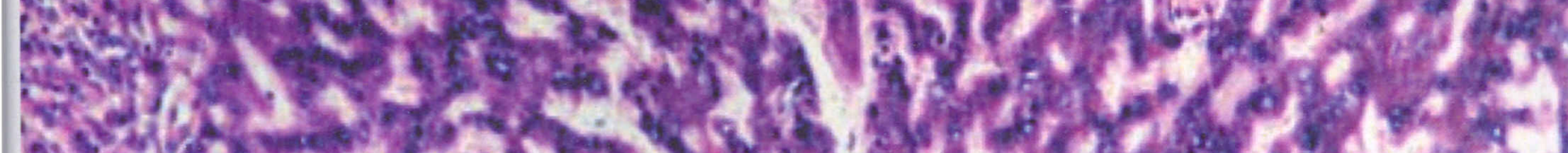
W. Fof.

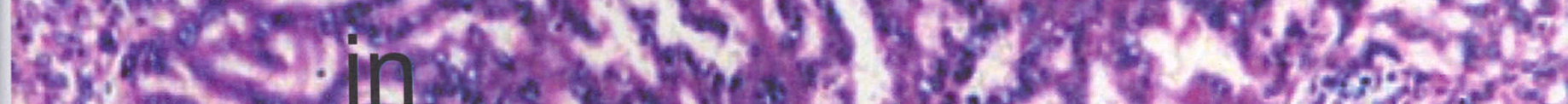

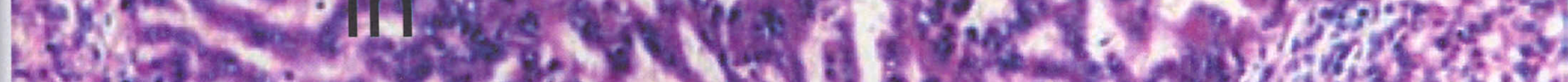

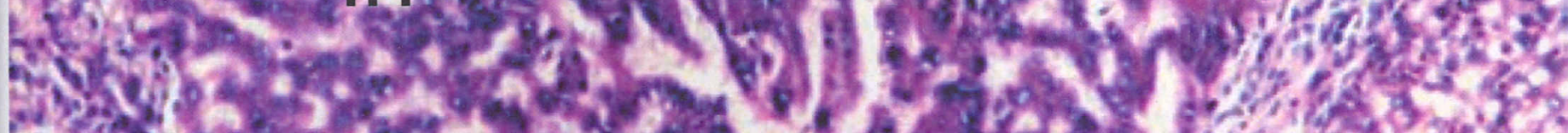

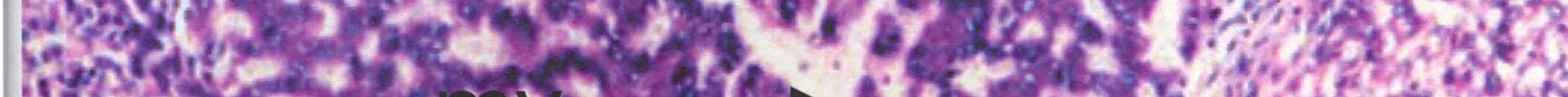

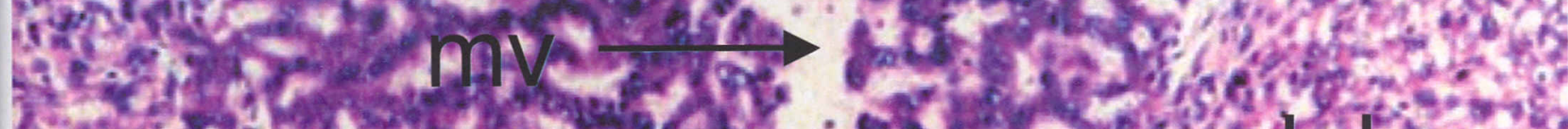

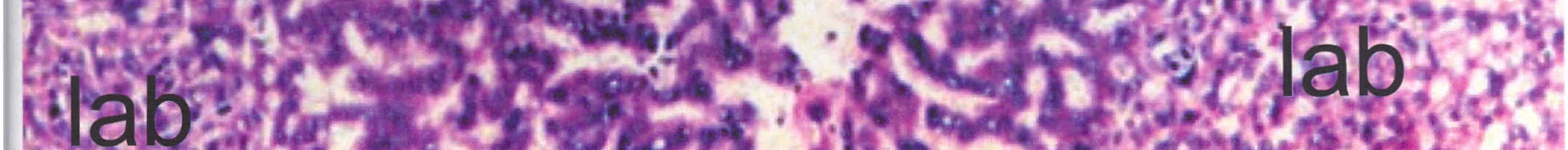

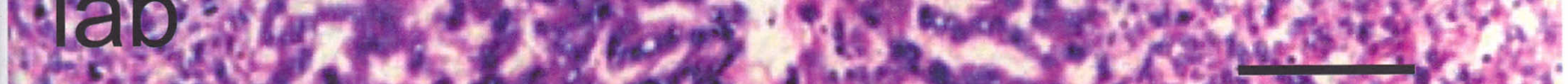

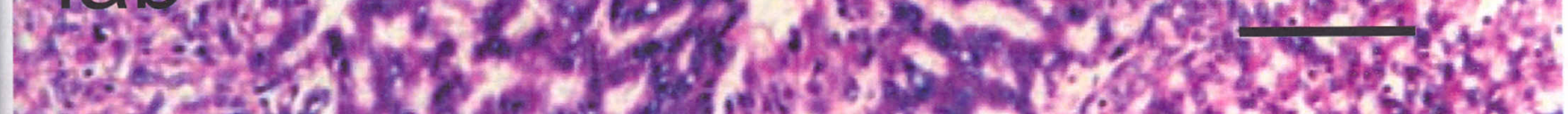

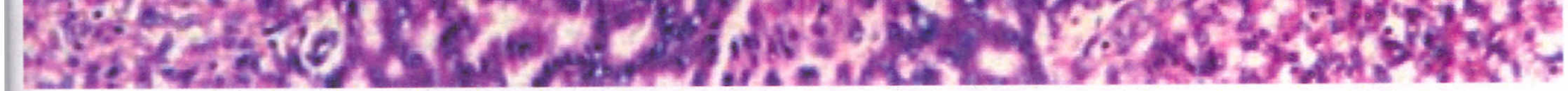

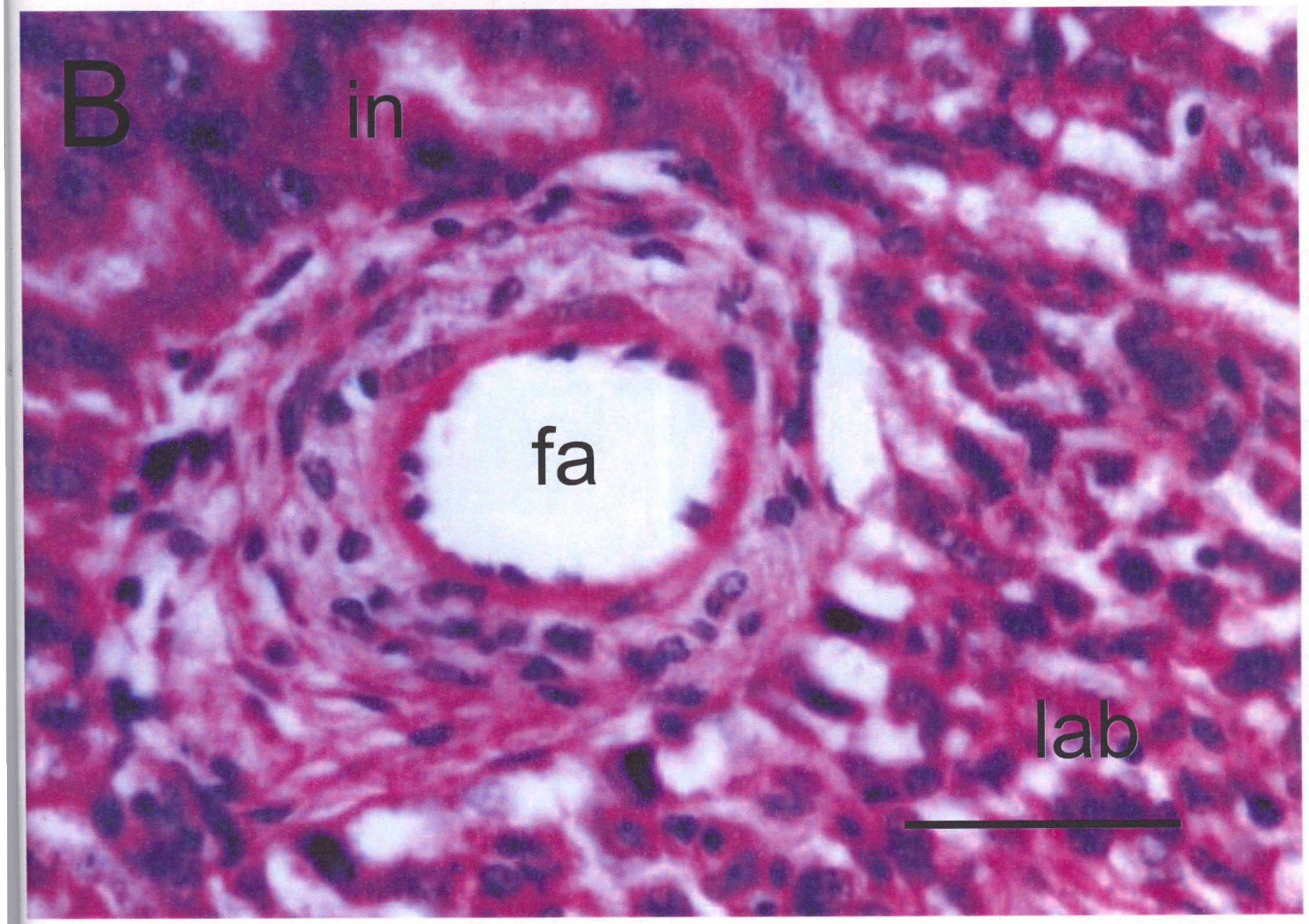



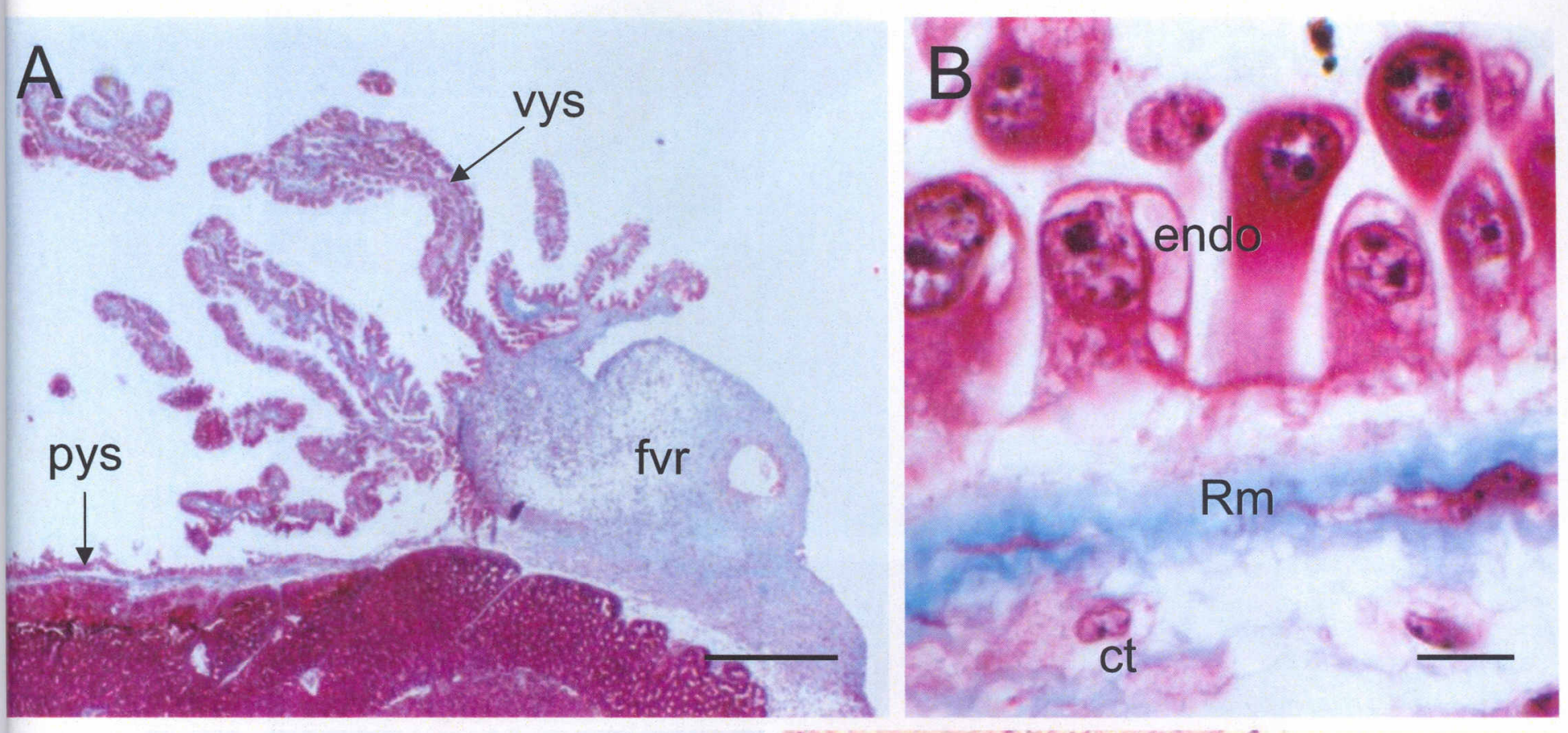

\section{C}

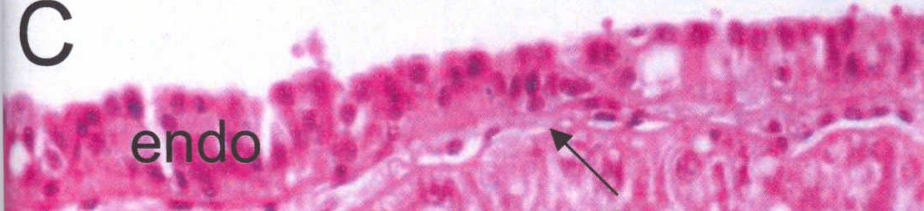

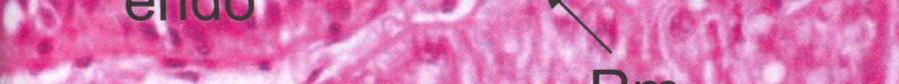

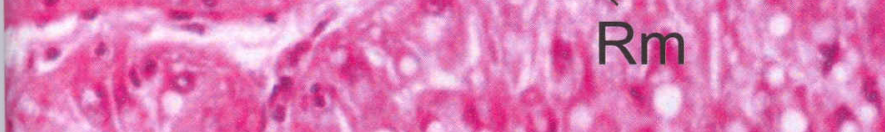

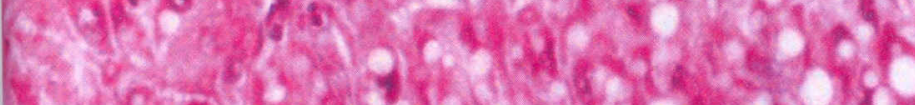

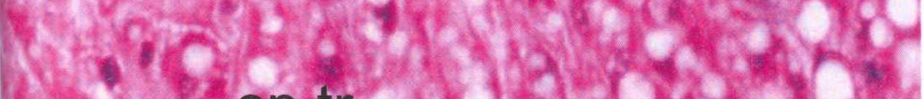
F.

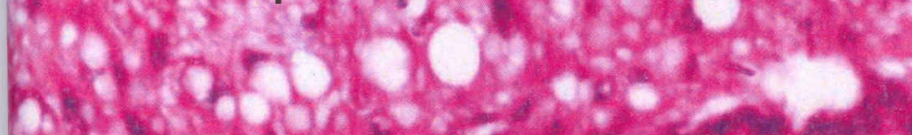

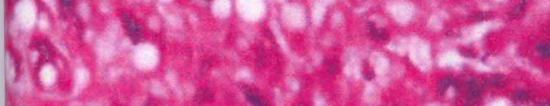

as

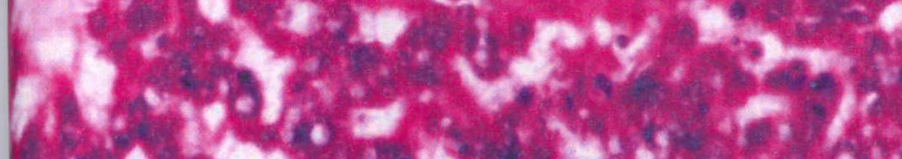

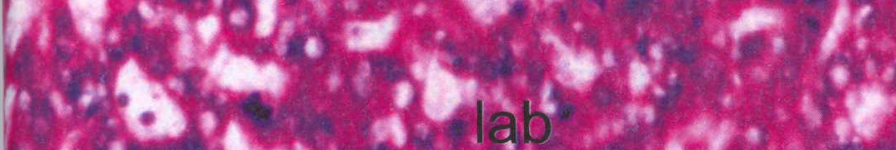
6.5 $70 \mathrm{sin}^{2}$

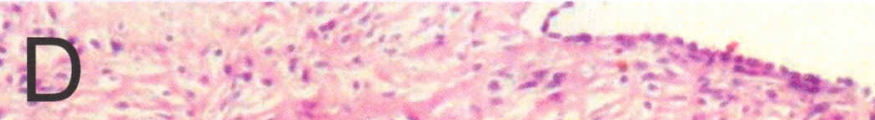

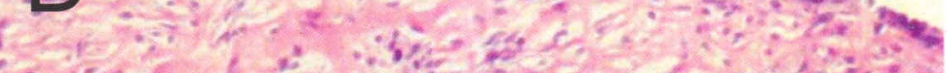

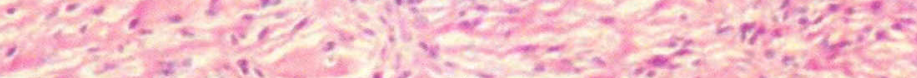

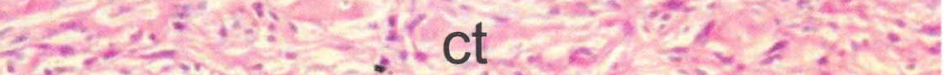

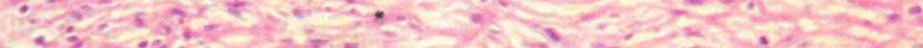

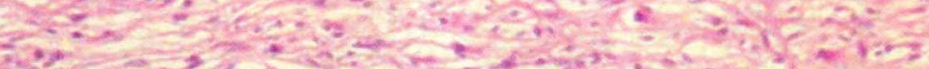
(2)

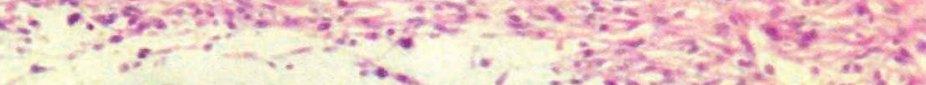

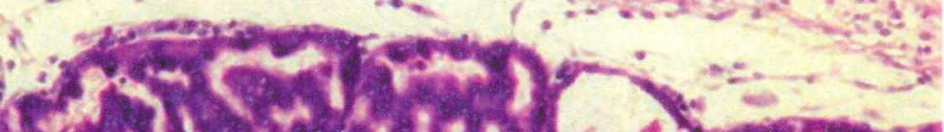

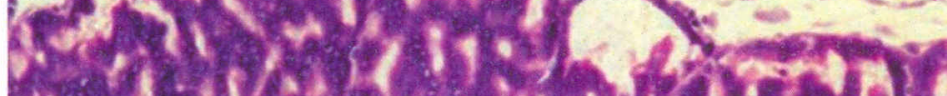
* t.

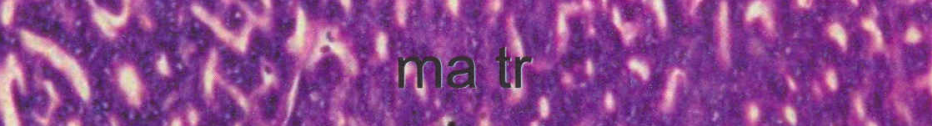

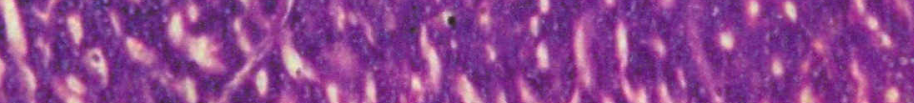

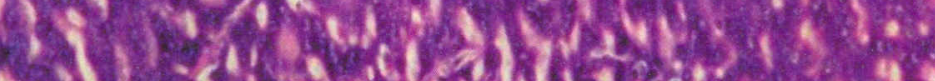

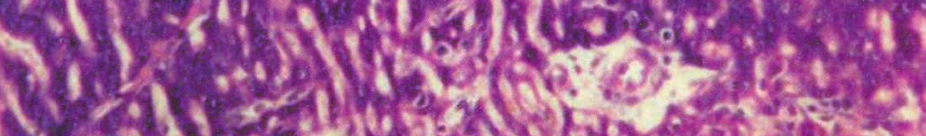

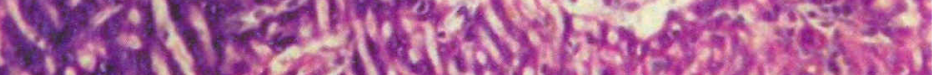

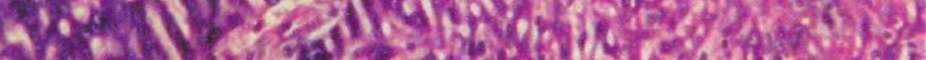
4.

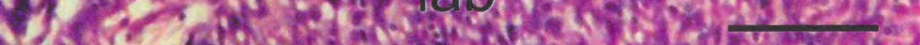
(1) 

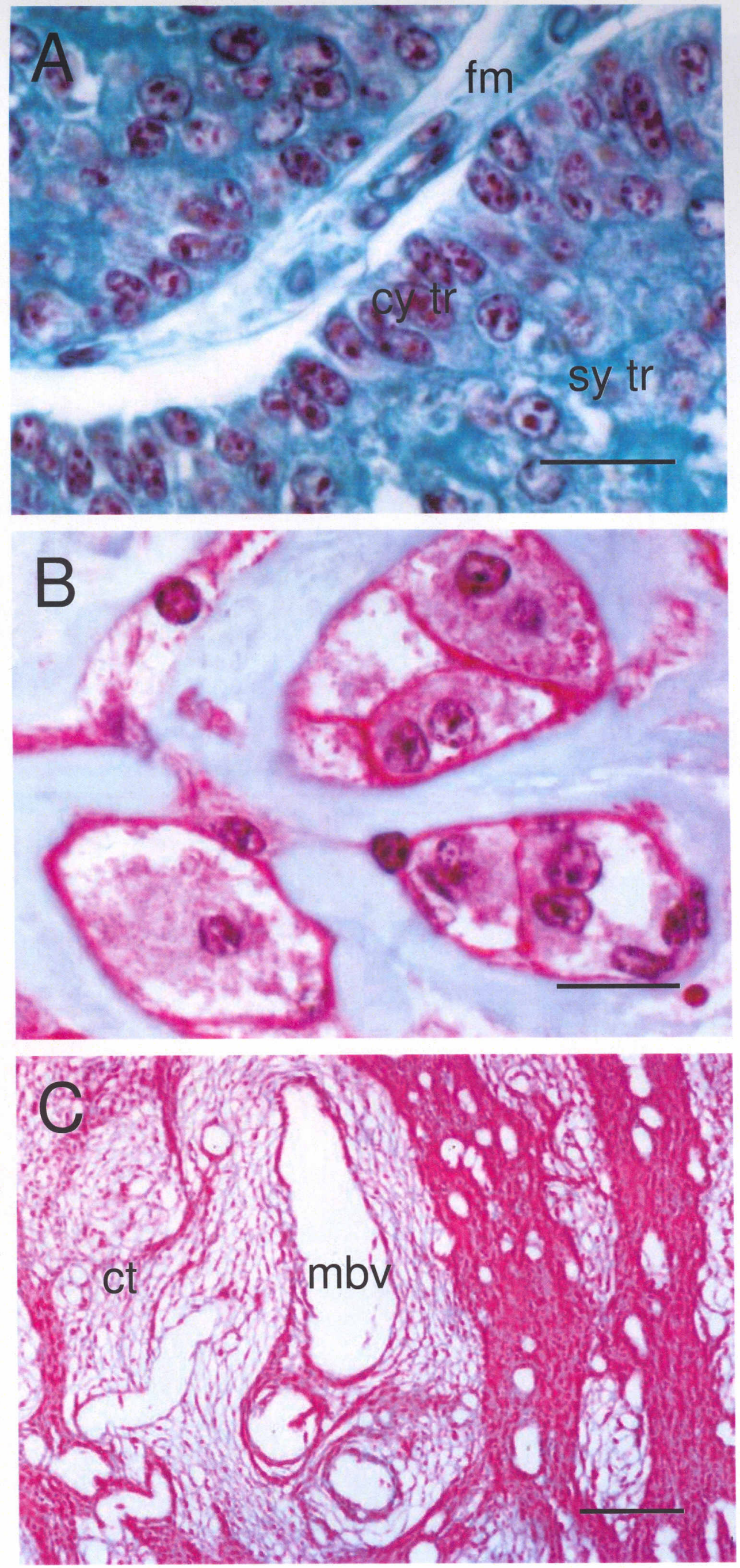


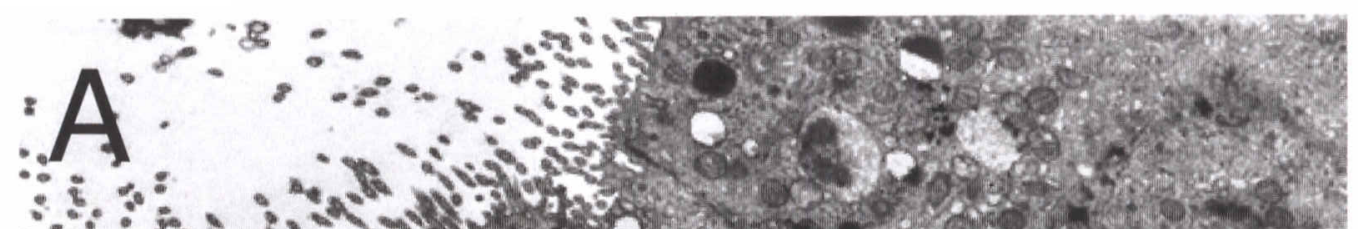
$\therefore 0$ a

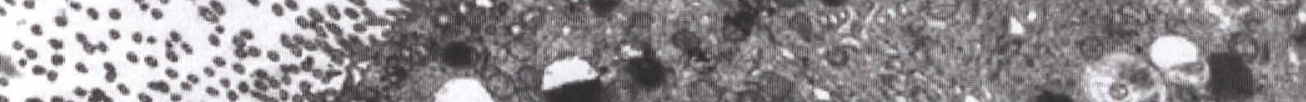

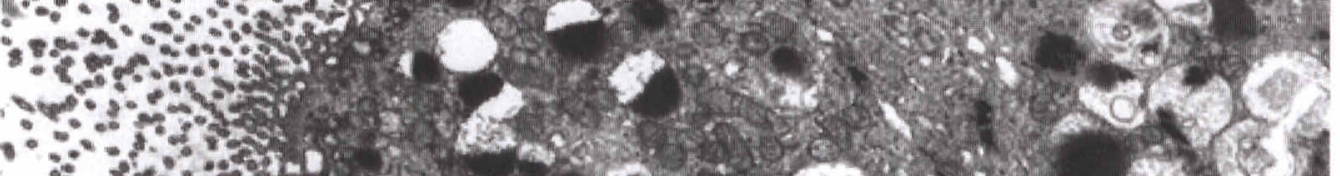

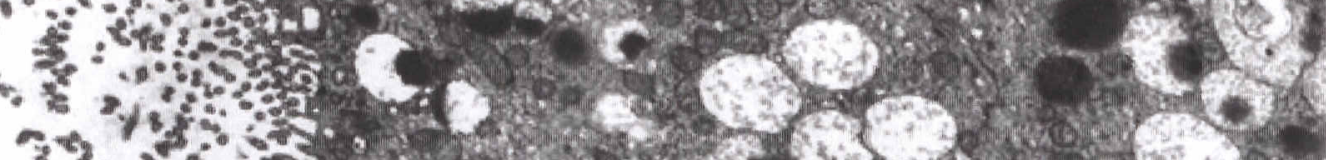

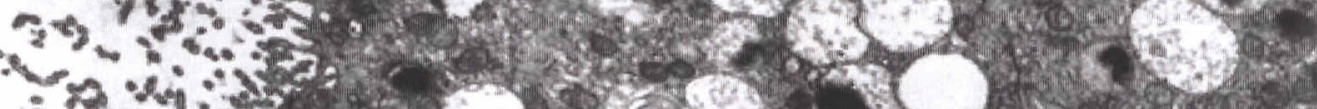

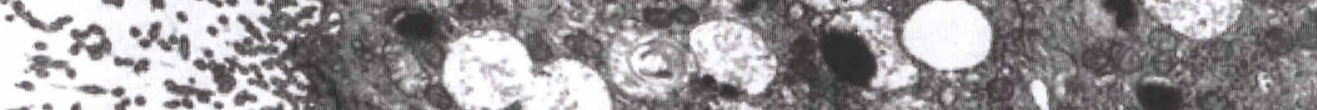

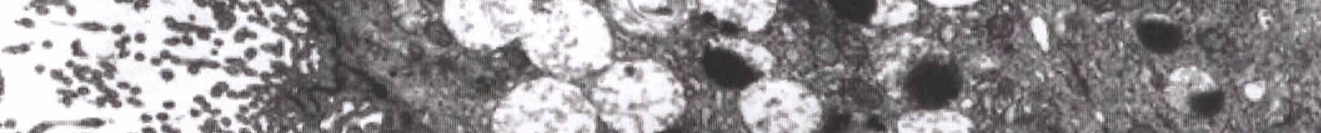

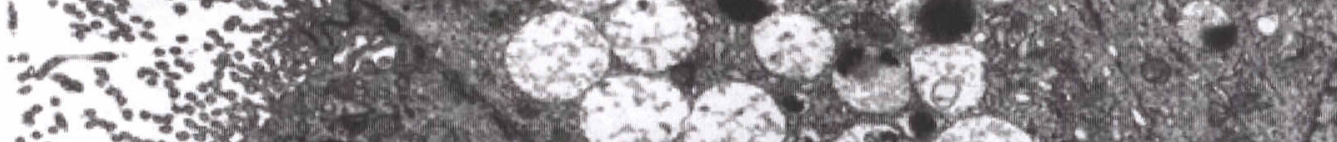

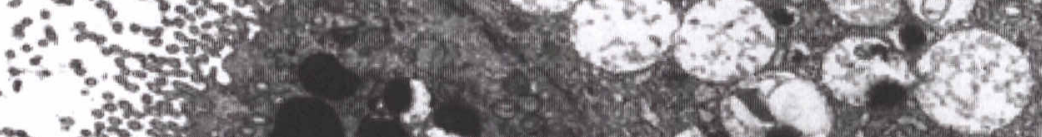

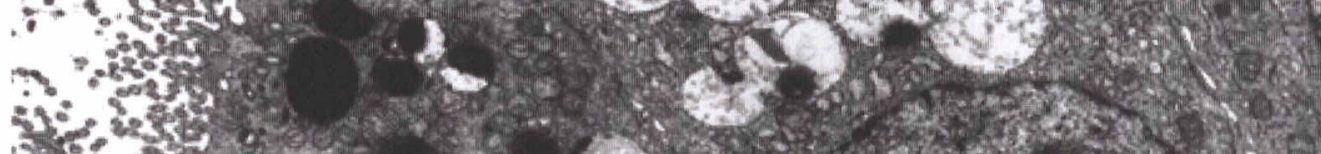

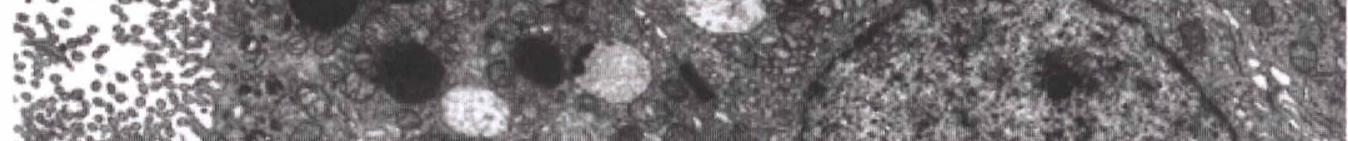

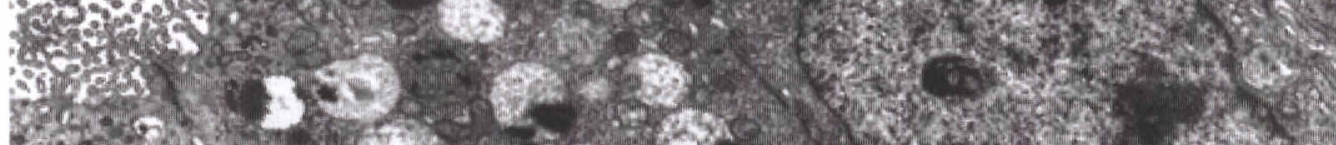

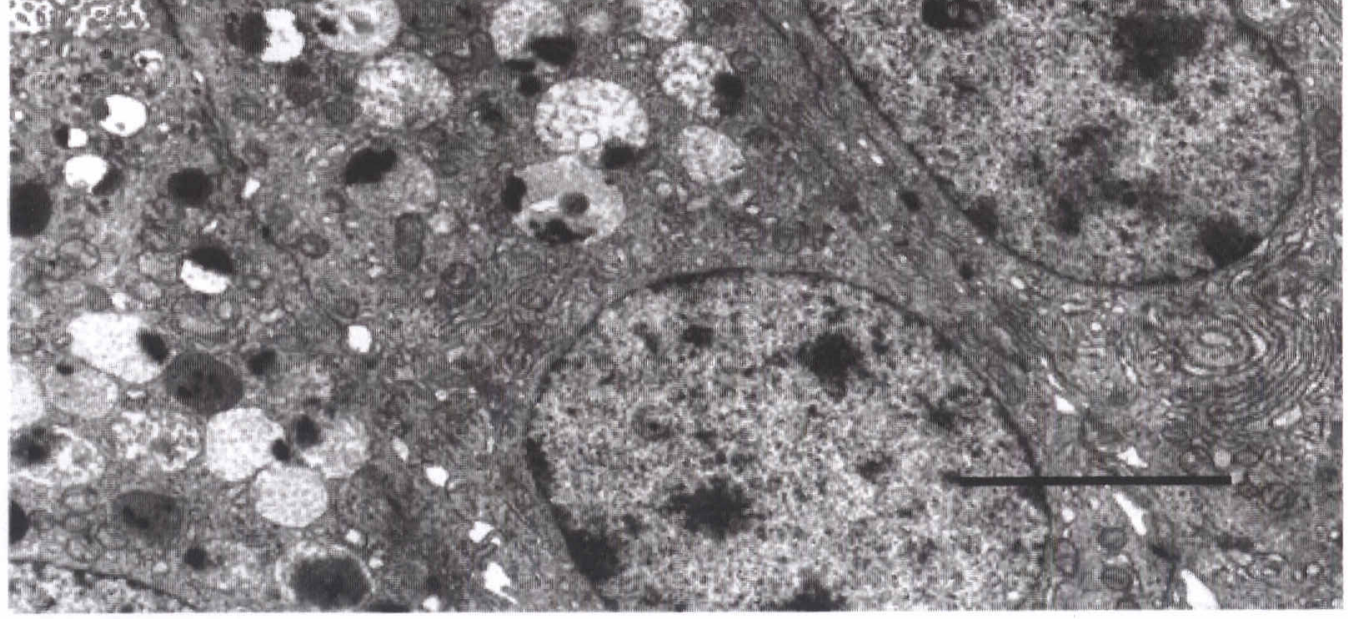

B

e

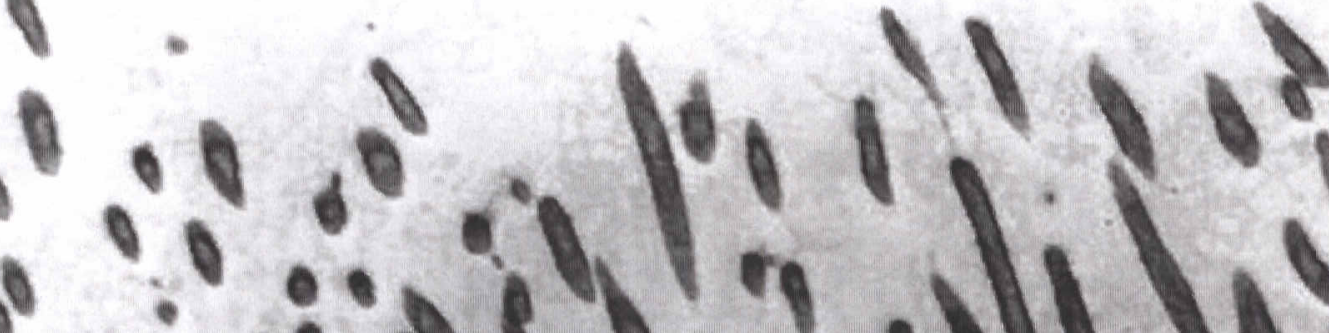
$\therefore 01.210$. 1111 0 . 30 ll ming $1:$ i 1 in 3010 CV

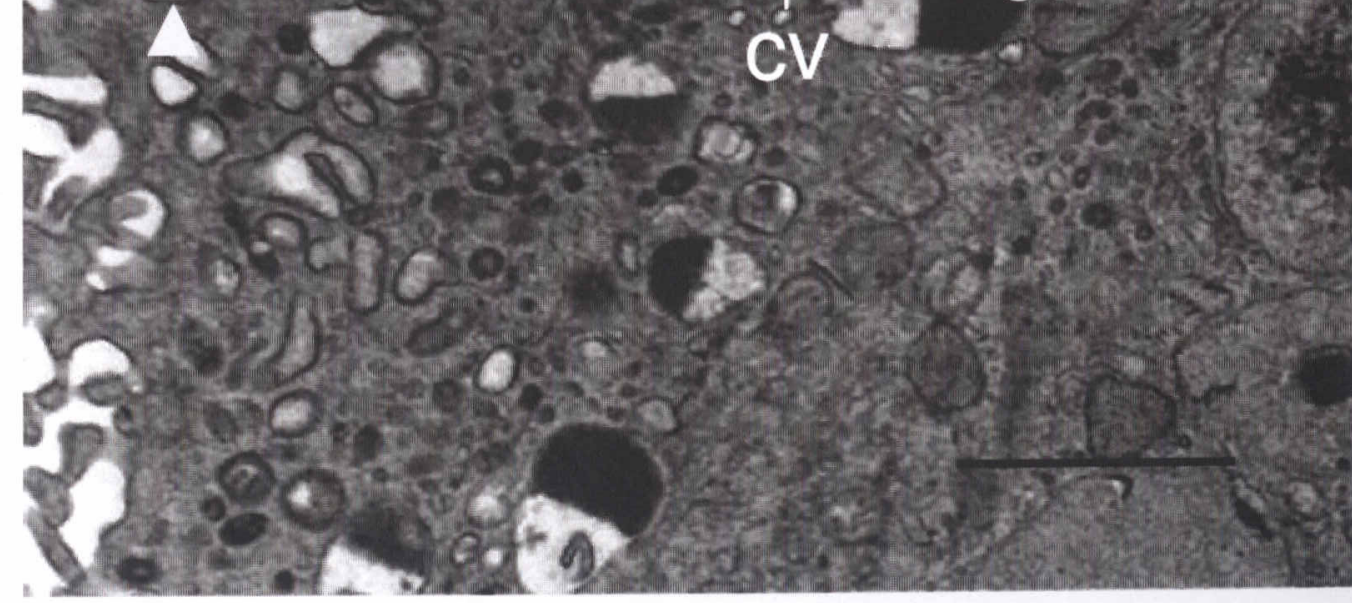

